176

L52

GITIMACY

AND THE

INFLUENCE of SEASONS UponCONDUCT ALBERT LEFFINGWELL,MD.

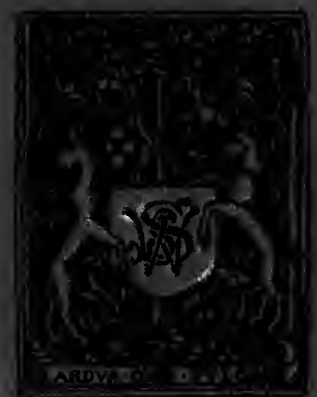




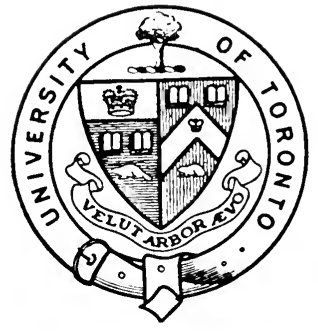

Presented to the

\section{UNIVERSITY OF TORONTO}

LIBRARY

by the

\section{ONTARIO LEGISLATIVE}

LIBRARY

1980 


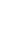


Digitized by the Internet Archive in 2007 with funding. from Microsoft Corporation 


\section{ILLEGITIMACY}

AND THE

INFLUENCE OF SEASONS UPON CONDUCT 





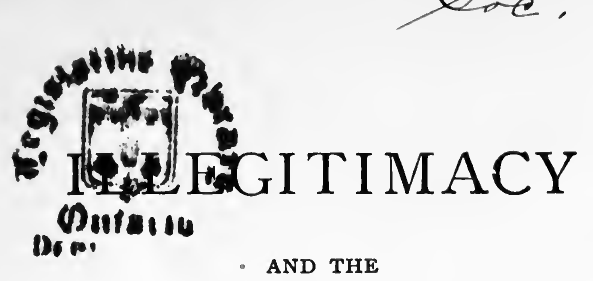

Dac: Limo

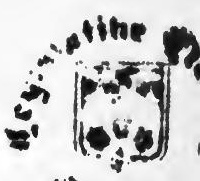

(v)iriariu

II. 0.0

\section{INFLUENCE OF SEASONS UPON CONDUCT}

TWO STUDIES IN DEMOGRAPHY

BY

ALBERT LEFFINGWELL, M.D.

Member of the International Congress of Hygiene and Demography

With Maps and Diagrams

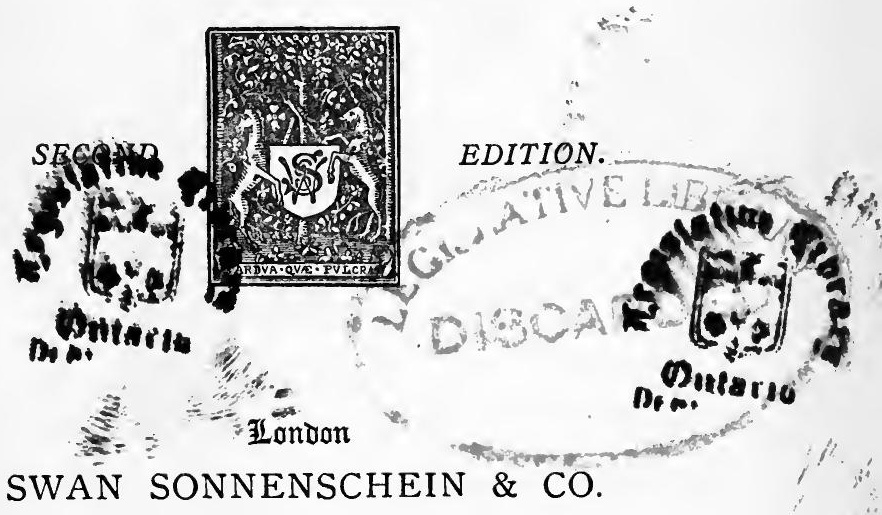

NEW YORK : CHARLES SCRIBNER'S SONS 


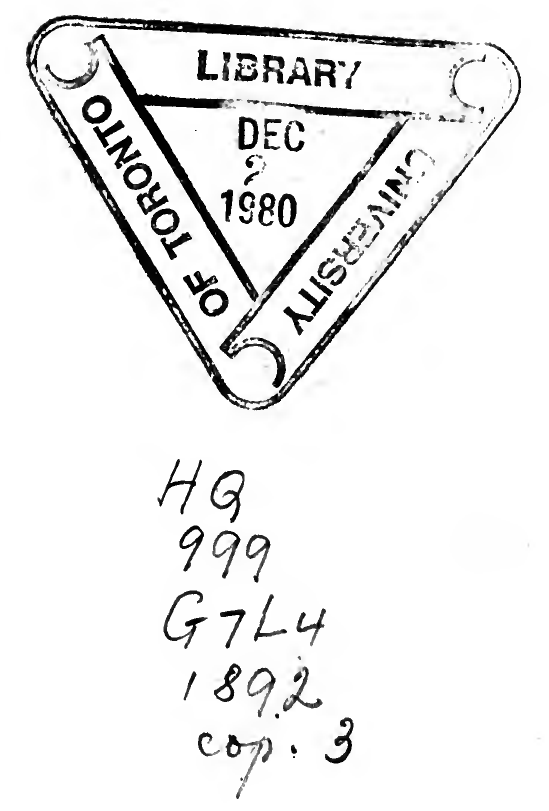




\section{P R E F A C E.}

THE present volume contains the first treatise in the English language, upon the subject of Illegitimacy. On the Continent this phase of social phenomena has attracted considerable attention; but investigations have been chiefly confined to countries possessing comparatively little interest for the English reader.

The following pages are devoted largely to a consideration of illegitimate births in the different sections of the British Isles.

The second essay is an attempt to present to the reader certain phenomena of periodicity in human conduct and mental disease, which, although for many years familiar to students, are still comparatively unknown to the general public. To what extent the hypothesis advanced accounts for all the facts observed, each student must judge for himself. At all events it is believed that the statistics herein for the first time grouped together will be of permanent interest.

The writer has aimed to present some statistics of human conduct, now buried in official reports, in such a way as not only to be easily intelligible but also interesting. He believes it a mistake to imagine that facts must necessarily be dull, or figures dry. No romance evolved from the imagination of the novelist can ever compare with the tragedies of real life. What we wish to know is where to find the truth, and how to interpret it.

To what extent, then, the reader may ask, can confidence be placed in the accuracy of the statistical 
facts herewith presented ? How may they be verified? What are the sources from which they have been derived? Do they represent original investigation or have they been copied from other works ?

Each tabular statement in this volume relating to Great Britain is the result of personal research and reference to the original official sources of information, -excepting only in one or two cases where the contrary is stated. The annual rates of Illegitimacy, for instance, in different sections of the country are derived from the reports of the Registrar-General. The authority for all other statistical averages is usually given in the text. An opportunity for personal verification of diagrams and tables is largely afforded by the detailed statements contained in the Appendix.

To insure the highest degree of accuracy, every tabular statement presents the statistics of several successive years. It is conceivable for instance, that one might mistake in calculating the illegitimacy of Scotland as about three times that of Ireland,- - taking a single year as a basis. It is infinitely improbable that precisely the same error should be repeated in a dozen calculations, over a dozen years. While the author believes that even slight inaccuracies will not be found in the transcription of the figures herein contained, he is certain that no error sufficient to invalidate conclusions can possibly have occurred.

To Mr. F. Finch, of the General Register Office, Somerset House, the author is indebted for valuable assistance.

4, Regent Street,
Uxford.

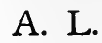




\section{CON TEN T S.}

ILLEGITIMACY :-

PAGR

Prevalence in Great Britain and Ireland since 1879 . 5

Probable Rate in England, I890-1900 . . . 8

Differences in England, Scotland, and Ireland . . I I

Relation to Unmarried and Nubile Womanhood $\quad 17$

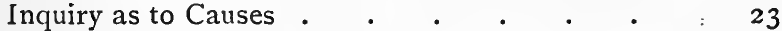

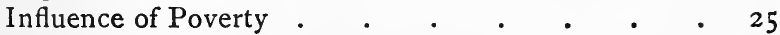

" "Country and Town Life . . . . 30

" "Education . • • • • • • 35

" " Religion • • • • • • • 40

" $\quad$ "Legislation and Restraints to Marriage . 43

Age of Illegitimate Mothers . . . • 66

Social Condition of Illegitimate Mothers • • $\quad 67$

Concealment of Births. . . . • • • 68

Mortality of Illegitimate Infancy . • . $\quad 70$

Influence upon the Fusion of Races . $\quad$ - $\quad$ - 74

Individual Cases of Eminence . . . . $\quad$ - 76

Prevention and Amelioration . . . . . 80

Conclusions . . . . . . . . $\quad$. 85

The Influence of Seasons:-

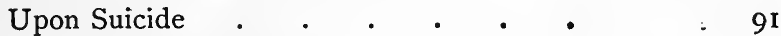

" Attempts at Suicide • • • • • • 94

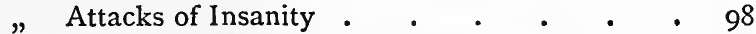

" Murder and Murderous Assaults . . . 106

" Crimes against Chastity . . . . . 108

" All Crimes against the Person . . . . II3

" Birth-rates (Legitimate and Illegitimate) . . II5

" Marriage and Divorce . . . . . I2I

, Revolutions and Insurrections . . . . 124

Hypothesis of Solar Influence . . . . . 132

APPENDIX I. :-

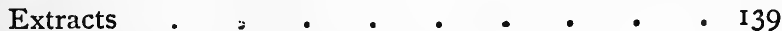

APPENDIX II.:-

On the Value of Statistics . . . . . . 146 
STATISTICÁl' TABLES.

Illegitimate Births. England, Scotland, and Ireland 6

$"$

99

9)

99

in certain English Counties, ro years . . . . . in certain Scotch Counties, 12 years . . . . . to each I, ooo Unmarried Women, 15-45, in England, Scotland, and Ireland . . . . .

COMPARISONS OF ILLEGITIMACY-

English Counties .

Irish Certain Cities and Country Districts : .

WORST DISTRICTS OF ENGLAND, I 842 and I887.

EASTERN COUNTIES, 1842 and $\mathrm{I} 887$.

INFLUENCE OF SEARCH FOR PATERNITY AS A Right

ILlEgitiMATE BIRTHRATES IN DIFFERENT COUNTRIES

OF EUROPE (noting prevailing Religion of each) .52

COMPARISONS OF IllegitimaCy IN SCOTLAND . 61,63

Age AND SOCIAL Condition OF Illegitimate

\section{MOTHERS}

$\cdot \quad \cdot 70$

SEASONS AND SUICIDE, JAPAN • • • • • • 93

$" \quad " \quad$ ATtempts at Suicide, ENGland . • 95

" SUICIDE IN LONDON (20 years) $"$; 96

Curve Diagram : Attempts at Suicide, England and

Wales .

Seasons and AtTacks of InSanity, Scotland. . IOI

$" \quad " \quad$ SUICIDES DUE TO MADNESS OR OTHER CAUSES . . . . . . . . . 103

$"$ " Murders aNd Homicidal Assaults, ENGLAND . . .

CRimes against Chastity, England AND WALES . . . . . IO9, II2 Crimes against the Persons England, FRANCE, AND IRELAND

BIRTH-RATES, Legitimate and Illegiti-

II 4 mate . . . . I16, II7, II8 BIRTH-RATE, É I840-I880 (Diagram) . . . . I 20

INFLUence OF Seasons UPON VARIOUS Phases of

CONDUCT . . . . . . . . . I26-127

Theory OF Relation Between SOlaR INFLUence

AND CONDUCT . . . . . . . . 136 Appendix II.-Various Statistical Tables : . 147-160 
illegitimate child. By forbidden paths she has attained the grace of maternity; but its glory is for her transfigured into a badge of unutterable shame.

It might be thought that a social phenomenon so universal, yet so sad, would not be left chiefly to the pen of the novelist or poet; and that more frequently some endeavour would be made to fathom cause and seek prevention of an evil so nearly affecting human happiness. Perhaps because regarded as the unmentionable in social life, illegitimacy has been so lightly passed over by serious literature. But a phase of human experience touched by the genius of Scott, of Goethe, of Victor Hugo, and Nathaniel Hawthorne, need not be shuffled out of sight as too repulsive for consideration.

In its relation to modern society, the subject of illegitimate births presents itself as a problem for scientific investigation; a problem, too, bristling with inquiries of the utmost interest. To what extent, for example, does it prevail among the most civilized people? How is it affected by poverty and destitution? 'Is it checked by the diffusion of education and increased by 
ignorance? Is it influenced by religion, and may we detect any difference in the deterring suasion of diverging creeds? Is the phenomenon a constant factor in a nation's birthrecord year after year? Is it increasing or decreasing? What is the influence of race, of legislation, of public sentiment ?

These are certainly questions of interest; but the replies thereto are, for the most part, inaccessible to the general reader. Let us see to what extent they may be answered by an investigation of facts.

Every science of to-day is based upon the accumulation of observed phemonena. No clever hypothesis, no imposing array of venerable opinions, may serve as the substitute for actual knowledge; and when this is wanting and observation impossible, science is satisfied to confess its ignorance. Now, statistics, when gathered without other object than to record events as they occur, are of peculiar and special value. They are the record of events; not the building of hypotheses. In contemplation of them we stand, as it were, in audience with Truth itself, as distinct from that vague shadow of truth which the best opinion and most careful 
estimate-apart from the facts themselves-can only be to us.

But, if the truth, are they the whole Truth? To what extent is their value vitiated by errors and omissions? Of course absolute accuracy cannot be hoped, especially in respect to an event involving so much of shame and disgrace. Concealment and infanticide undoubtedly make the record everywhere less frightful than its awful reality. But taking the statistics afforded by governmental reports, we may be almost certain that they are now gathered with such absolute indifference to results as should always characterize the search for truth; and that, apart from concealment, the errors in our day, at least, are so infinitesimal in number as not in any appreciable degree to impair their value.

Of this there is one remarkable proof, to which the attention of the reader cannot be too frequently directed; it is the persistence of the phenomena year after year, with but slightly varying difference. This is one proof of accuracy in statistical evidence, for it is highly improbable that precisely the same error would repeat itself over a series of years. Science is inclined to doubt the alleged phenomenon that 
is not and cannot be repeated; the physician places little reliance on the drug which continually varies in effect. For, as a rule, Nature presents us with uniform continuity in the operation of her laws; and we learn to expect from their operation, in any given period of time, not merely order, but a certain degree of persistence of repetition and invariableness. When, therefore, we discover that any event in human conduct is, year after year, so regular in appearance, so uniform in number, as almost to justify prediction for years to come, we may be almost certain that we are studying the effect of law. Take, for example, the number of illegitimate births, returned by the Registrar General of Births, Deaths, and Marriages, in each of the three principal divisions of the United Kingdom. [See Table I.]

This is certainly a remarkable exhibit. No one can study it, or note the even steps with which, year after year, this history of shame and sorrow repeats itself for over a quarter of a century, without a certain feeling of awe. Here is an event, involving in forty thousand English homes a certain degree of social ruin and disgrace; yet it recurs again and again, 
year after year, in almost precisely the same numbers, in almost exactly the same average frequency! Let the eye glance, for instance, on the figures representing the number of illegitimate births in England and Wales, say in 1879 , and then let us try for a moment to

Table No. I.-Illegitimate Births in England, SCOTLAND, AND IRELAND SINCE 1879.

\begin{tabular}{|c|c|c|c|}
\hline & England. & Scotland. & Ireland. \\
\hline х 879 & $42, x 89$ & 10,727 & 3,367 \\
\hline 1880 & 42,542 & $10,5^{89}$ & $3,2 \circ 3$ \\
\hline I 88 I & 43 , I 20 & Io, 484 & 3, I98 \\
\hline I 882 & 43, I 55 & 10,546 & 3,268 \\
\hline $188_{3}$ & 42,646 & I O, I I 4 & 3,049 \\
\hline I 884 & 42,667 & Io, 439 & 3 , I 99 \\
\hline I 885 & 42,793 & Io, 680 & 3,218 \\
\hline I 886 & 42,838 & I 0,506 & 3,079 \\
\hline I 887 & 42,134 & $10,3^{6} 5$ & $3,18 \mathrm{I}$ \\
\hline 1888 & 40,730 & 9,968 & $3, \mathrm{I} 24$ \\
\hline I889 & 40,627 & 9,643 & 3,049 \\
\hline
\end{tabular}

bring before the mind some conception of the suffering and sorrow; of the apprehension and dread; of the sense of immeasurable disgrace, felt not only by mothers themselves, but by relations and friends, which this vast number of unlawful and unblessed births occasioned on 
every side. Forty-two thousand, one hundred births registered as illegitimate!-almost three times as many children as are born in all the homes of Liverpool and Birmingham every year! Let us picture to ourselves the influence of these sad examples of frailty; the warnings which they occasioned; the moral each one pointed; the admonitions it enforced; the resolutions they occasioned; and then estimate, if we can, the probable effect all this might be supposed to have in diminishing the evil in years to come. Then drop the eye a line lower to the figures for the next year; and there is the same story of trouble and disgrace; the same number of births, increased less than one per cent., meets our gaze. The suffering, the unspeakable dread, the anguish, the remorse has been doubled; the record is the same. We take the story of another year, and then the next, and how little is the variance! Why is this monotone of sorrow unbroken? Why is the tithe so pitiless in uniformity? For Nature does not more surely guarantee to the farmer the average product of his field than she gives to England, to Scotland, to Ireland, this annual harvest of sorrow and shame. 
In the study of facts like these, it seems to me difficult not to see the uniform operation of natural laws in the government of human action. We look in vain for evidence of the free play of volition, untouched by motives, undetermined by cause. Surely, if any step is ever made with the misgivings that would accompany an act of will, it would be that taken by so large a number of unmarried women in commencing relations involving consequences so serious throughout life; and we should suppose that by no possible method could science determine the results of human choice governed by motives apparently so inscrutable. Yet precisely the contrary is true. We can predict; and prediction of that which is to happen in future, is the test of science. With quite as much certainty as the Chancellor of the Exchequer calculates the average income of his budget a few months in advance, can the statistician predict the number of illegitimate births which will occur for years to come. Certain exceptional circumstances may conceivably arise to disturb or vary the result, precisely as a war or a famine might overturn every calculation of $\mathrm{Mr}$. Gladstone or Mr. Goschen; but the chances of 
such an event are very small. How many women in England and Wales, the great majority of whom are to-day in innocent and happy girlhood, will hold in their arms in 1893 the unwelcome offspring of shame? Impossible to say? Why, we cannot conceive that the number will be so few as 25,000 , unless some awful convulsion of Nature, an earthquake, a famine, or the plague, shall destroy our population by the hundred thousand; or some great war or invasion disturb society to its very foundation. Making every allowance for the action of agencies which is steadily and happily decreasing this social evil, we can hardly conceive of a lower number than 35,000 illegitimate births in 1893 and 1894 . The actual number will probably be nearer 38,000 . Or to predict with yet greater precision, we may say, that of every thousand children born in England and Wales during the year I893, at least 42 or 43 will be illegitimate. So assuredly can we depend upon the uniformity of the laws that govern human conduct, that we know what results will occur through passion and folly for years in advance.

No imaginable human agency except war 
could by the year 1892 or 1893 lower the ratio of births out of wedlock to, say, thirty per thousand. Without a sudden revolution in moral sentiment equally impossible, the rate of illegitimacy could not rise in this country to sixty per thousand in so brief a period.

I have little doubt, that during the few remaining years of this century, the rate for England and Wales will vary between fortythree and forty-eight per thousand births. Illegitimacy therefore is an example of human action, based apparently upon the fluctuating impulses of passion, involving the exercise of all that we call "free will" in one of the most important emergencies of individual life, yet, on the whole, governed by fixed and immutable laws. Hidden beyond present knowledge, unknown, and possibly as unknowable, are the ultimate causes of all phenomena, whether it be the course of a planet in its orbit, the fall of an apple to the earth, or the uniformity of human action from year to year. Perhaps, however, it is possible to discover some of the proximate circumstances which apparently regulate this special manifestation of illicit conduct. 
The differences in this respect to be observed among the people of different nationality, opens a field for investigation to which I shall refer hereafter. We are in the habit of ascribing all disparity of conduct or morals existing among different populations to a variety of causes and special influences. With the great majority of us it is a fixed though unwritten creed, that nearly all the immorality of this world might be eradicated in some way by the general diffusion of knowledge, the increase in national wealth and prosperity, and, above all, by the more general acceptance of our own special and particular form of religious belief. The problem hardly admits of so easy solution. What, for instance, are we to make of differences in this respect among people of allied and intermingled lineage, guided by the same Government, living side by side in the same latitude, speaking the same language, holding to the same standards of moral obligation? The most interesting of problems is suggested by this inquiry. Any one who examines the comparative frequency of illegitimate births occurring, say, in England, Scotland, and Ireland during a term of years, can hardly fail to be 
impressed by the singular differences to be observed. The number of children born outside the marriage relation in each country does not permit that comparison we require; it is necessary that we ascertain what proportion these illicit births bear to the total number of children born.

The following table therefore is of special value since it indicates the prevalence of Illegitimacy in each of the three divisions of the United Kingdom for a period of years.

Table II.-Of each Thousand Children born in England, Scotland, and Ireland, how many WERE ILLEGitimate?

\begin{tabular}{|c|c|c|c|}
\hline Year. & Ireland. & England. & Scotland. \\
\hline I 878 & 23 & 47 & 84 \\
\hline 1879 & 25 & 18 & $8:$ \\
\hline 1880 & 25 & 48 & 85 \\
\hline I $88 \mathrm{I}$ & 25 & 49 & 83 \\
\hline $\begin{array}{l}1882 \\
\text { I }\end{array}$ & 27 & $\begin{array}{l}49 \\
49\end{array}$ & 83 \\
\hline $\begin{array}{l}1883 \\
\end{array}$ & 26 & $\begin{array}{l}49 \\
48\end{array}$ & $8 \mathrm{I}$ \\
\hline I 884 & 27 & 47 & $8 \mathrm{I}$ \\
\hline I 885 & 28 & 48 & 85 \\
\hline 1886 & 27 & 47 & 82 \\
\hline I 887 & 28 & 48 & 83 \\
\hline I 888 & 29 & 46 & 81 \\
\hline & & $4^{6}$ & 79 \\
\hline
\end{tabular}


Here is the record for more than ten years ; and curious enough we find it. Year after year, of each thousand births in Scotland, there are almost twice as many illegitimate as in England and Wales; and more than three times as many as in Ireland. Even if this were an exceptional phenomenon it would command attention; but it is almost the invariable rule, extending over an entire decade, and going back, it may be, for centuries, in the past. What conclusions are we to gather from these facts? That the peasant mother of Ireland is more solicitous for the chastity of her daughters than her sisterhood of Scotland and England? Are the precepts of virtue more highly prized and effectively inculcated in the mud-cabins of Mayo, than beneath the thatched roof of the Highland cotter? Or is superior virtue the result of education? Why, the Irish peasantry are steeped in ignorance, as compared with the labouring population of North Britain. Shall we infer that vice and poverty go hand-inhand? But an Englishman would not kennel his dogs in such cabins as I have seen in Achill and Western Ireland. Can it be the effect of religious training and influence? But Scotland 
rejoices in the open Bible and the right to private judgment; while Ireland submits her conscience to the control of her priesthood and the guidance of an Infallible Church. I have no intention to dismiss with a phrase or a surmise any of these conditions or circumstances; if their influence is here apparently questioned, it is simply that the reader may perceive some of the difficulties of the problem which check all attempts at any off-hand solutions.

But another singular fact confronts us. Not only has each great political division of Europe its special illegitimacy average, which it repeats pretty regularly year after year, but each department and county, each city and neighbourhood, has its own particular tribute of bastardy, which, with almost unfailing regularity, it contributes to the sum-total of the nation! Ireland, for instance, does not differ more widely from England or Scotland than its counties differ from each other; and although the variance from a uniform rate for a county is a trifle greater than for a nation, yet the figures are fairly steady from year to year. For instance, let us compare certain English and Welsh counties, showing specially high rate, with 
other parts of England. In this table the annual ratio is given for several successive years :-

Table III.-To r,oo0 Births in Different Sections of ENGLAND and Wales HOW Many Were Illegitimate during a Period of Ten Years?

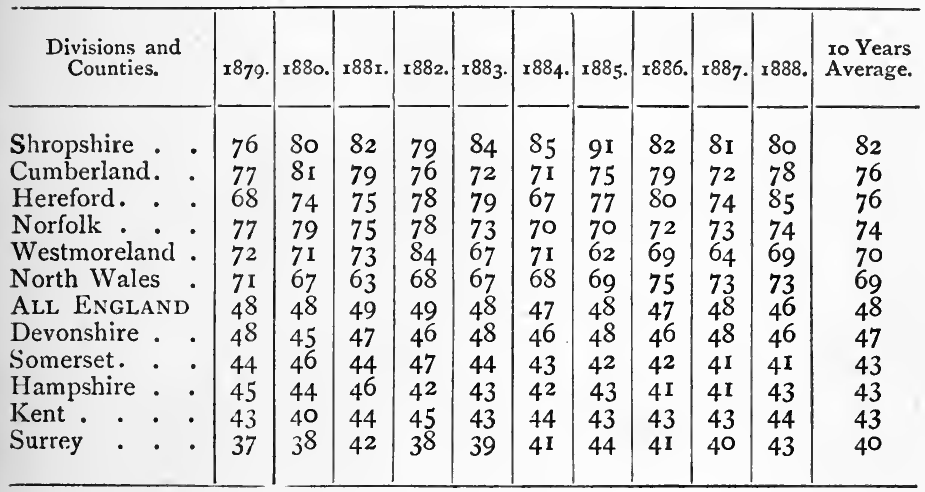

This is the record of ten years. Every year one section of the country pays twice the tribute of another part; and yet both sections are equally under English laws, English customs, English civilization. What, one may well ask, are the influences, the circumstances, the conditions, which produce such surprising contrasts between the social morality of Devon and Norfolk, or Surrey and Shropshire?

But England is not the only country where 
a wide divergence of morality may be observed. In Ireland the contrast between different counties is even greater than elsewhere in the United Kingdom. In Scotland the average ratios of comparative prevalence of illegitimacy are everywhere high, yet not everywhere alike. For instance, compare the rate prevailing for many years in the following sections of Scotland:

Table IV.-Of each i,ooo Births in Different Parts of SCOtland, how many were Illegitimate?

\begin{tabular}{|c|c|c|c|c|c|c|c|}
\hline \multirow{2}{*}{$\begin{array}{l}\text { Ten Counties having } \\
\text { for Scotland } \\
\text { a Low Rate of } \\
\text { Illegitimacy. }\end{array}$} & \multicolumn{3}{|c|}{$\begin{array}{c}\text { Annual Rate to rooo } \\
\text { Births. }\end{array}$} & \multirow{2}{*}{$\begin{array}{l}\text { Ten Counties having } \\
\text { a High Rate of } \\
\text { Illegitimacy. }\end{array}$} & \multicolumn{3}{|c|}{$\begin{array}{c}\text { Annual Rate to } 1000 \\
\text { Births. }\end{array}$} \\
\hline & $\begin{array}{c}\text { Io Years, } \\
\text { I876-85. }\end{array}$ & 1886 & 1887. & & $\begin{array}{l}\text { Io Years, } \\
\text { 1876-85. }\end{array}$ & 1886. & 1887 \\
\hline 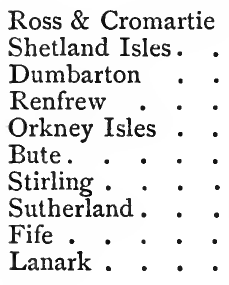 & $\begin{array}{l}47 \\
52 \\
54 \\
59 \\
62 \\
66 \\
66 \\
68 \\
68 \\
69\end{array}$ & $\begin{array}{l}48 \\
53 \\
52 \\
54 \\
65 \\
65 \\
67 \\
48 \\
64 \\
65\end{array}$ & $\begin{array}{l}49 \\
45 \\
49 \\
58 \\
79 \\
67 \\
65 \\
71 \\
63 \\
68\end{array}$ & $\begin{array}{l}\text { Nairn . } \\
\text { Roxburgh. } \\
\text { Caithness. } \\
\text { Kincardine : } \\
\text { Aberdeen : } \\
\text { Kirkcudbright } \\
\text { Dumfries. } \\
\text { Elgin . } \\
\text { Wigtown : } \\
\text { Banff . }\end{array}$ & $\begin{array}{l}106 \\
\text { I08 } \\
108 \\
\text { I } 25 \\
137 \\
\text { I } 46 \\
\text { J47 } \\
\text { I } 53 \\
158 \\
164\end{array}$ & $\begin{array}{r}146 \\
94 \\
121 \\
123 \\
142 \\
150 \\
138 \\
149 \\
162 \\
162\end{array}$ & $\begin{array}{r}94 \\
108 \\
127 \\
124 \\
135 \\
154 \\
137 \\
149 \\
181 \\
165\end{array}$ \\
\hline $\begin{array}{l}\text { Average of the } \\
\text { ro Counties. }\end{array}$ & $6 I$ & $5^{8}$ & 6I & $\begin{array}{l}\text { Average of the } \\
\text { Io Counties }\end{array}$ & 135 & 139 & 137 \\
\hline
\end{tabular}

Now, these differences are altogether too uniform to permit the hypothesis of mere 
accident or chance. The same singular phenomenon may be detected by comparing the different provinces, departments, or cantons of Italy, France, Switzerland, and Germany, or the subdivisions of every large State of Europe. We are justified, I think, in assuming that these divergencies, so marked in moral action and so uniform in appearance year after year, are due to some potent causes acting continuously, yet with varying force, in the different communities of the same nationality.

I have hitherto alluded only to the more common method of measuring illegitimacy, which consists in ascertaining the proportion of children born out of legal wedlock in every thousand births. While this test is fairly accurate, and is the most ready method for judging the underlying moral sentiment locally prevailing, there is yet another comparison which is sometimes possible: I mean, the number of illegitimate children born annually to each thousand unmarried females at the child-bearing age. For instance, in I88I the census of Scotland showed that there were then living in that portion of the kingdom 
492,454 unmarried women (that is, spinsters and widows), between the ages of I $_{5}$ and 45 . During the ten years $1878-1887$ there were born in Scotland 105,09 I illegitimate children, or an annual average of over $2 \mathbf{I}$ to each thousand unmarried females at this specified age. In England and Wales the corresponding number of the unmarried females was $3,046,43 \mathrm{I}$; and the number of illegitimate births during same period was 426,184 , or I4 to each thousand of the possible mothers. In Ireland the number of unmarried women at this age was a third larger than in Scotland, or 731,767. Yet to each thousand of these were born every year less than 5 illegitimate children, during a ten-year period, I878-1887. Here again we are perplexed with the problem why Scotia and Hibernia should present such widely different contrasts. Every year in Scotland there are five times the proportion of bastards that see the light in Ireland! Or, if we throw the figures into a diagram, and carry them out into decimals, we shall see the result as follows :- 
Table V.-To each Thousand Unmarried Women (Widows and Spinsters) between the Ages 15-45, how Many Illegitimate Children Were born anNually, I878I 887 ?

\begin{tabular}{|c|c|c|}
\hline Country. & $\begin{array}{c}\text { Rate of } \\
\text { Illegitimacy. }\end{array}$ & Proportionate Scale. \\
\hline $\left.\begin{array}{l}\text { Ireland } \\
\text { England } \\
\text { and } \\
\text { Wales } \\
\text { Scotland }\end{array}\right\}$ & $\begin{array}{r}4 \% \\
14 \% \\
21 \cdot 5\end{array}$ & \\
\hline
\end{tabular}

I have spoken of the persistency of these differences year after year. Is any break of continuity discoverable? Let us take, for instance, a county or group of registration districts which, at the present time, contrasted with some other localities, displays what, to put it mildly, we may call a lessened sensitiveness to moral injunctions. Year after year its rate of bastardy is considerably above the average for all England, and far exceeds that prevalent in other parts. Has this been the same for the past twenty, thirty, fifty years? Have Norfolk, and Shropshire, and Cumberland, not to speak of others, kept their undesirable pre-eminence ever since any knowledge of their moral status was available? 
And how far back through the past centuries has that stream of tendency been flowing? Unfortunately, our ancestors paid but little attention to the slow gathering of dry facts. The moral condition of English life, say for the past three hundred years, we know only by the pictures of men and manners drawn by novelist and dramatist ; in the adventures of Tom Jones or the perils of Pamela. It is hardly fifty years since the first attempt was made in England to get foundation facts about its moral condition in this respect.

Now, a priori, what should we say would be the story they reveal? Can we make the least guess as to the prevalence of illegitimacy forty or fifty years ago, or estimate the regions of greater or less proclivity? Not if all this is due to chance, independent of the law of causation. But if social phenomena depend upon the conjoint action of forces which have been continuously at work, then we should expect to discover that the area of least and the area of greatest tendency to immoral relationships are almost exactly the same, even if we contrast epochs separated by nearly half a century. 
Table VI.-Of Total Births, How Many of each 'Thousand were Illegitimate at Different Epochs? England.

\begin{tabular}{|c|c|c|c|c|c|c|}
\hline English Counties. & 1842. & 1862. & $\begin{array}{c}\text { Io years' } \\
\text { average } \\
\text { I } 863-1872\end{array}$ & $\begin{array}{c}\text { 10 years' } \\
\text { average } \\
1879-1888 .\end{array}$ & 1889. & 1892. \\
\hline Cumberland . & 114 & 113 & 110 & 76 & 79 & \\
\hline Hereford & 106 & 80 & 82 & 76 & 77 & \\
\hline Norfolk & 99 & 105 & 101 & 74 & 69 & \\
\hline Westmoreland & 93 & 112 & 95 & 70 & 72 & \\
\hline Shropshire & 93 & 98 & 94 & 82 & 79 & \\
\hline All ENGLAND & 67 & 63 & 59 & 48 & 46 & \\
\hline Hampshire & 64 & 55 & $5^{I}$ & 43 & 42 & \\
\hline Kent . . & 63 & 55 & 49 & 43 & 43 & \\
\hline Soinerset & 62 & 57 & 54 & 43 & 37 & \\
\hline Surrey . & $5^{2}$ & 47 & $4 \mathrm{I}$ & 40 & 39 & \\
\hline Devon . & $5^{\mathrm{I}}$ & 54 & $5^{8}$ & 47 & 43 & \\
\hline
\end{tabular}

It may be stated as a rule, that in English counties where an abnormally high rate of illegitimacy prevailed in 1842 , it has prevailed ever since; that in counties where the average was then less than for all England, it is less today; and that these peculiar differences have been in existence without great variation from one another, for almost half a century. For how much longer, we cannot say. Unrecognised and unsuspected, they have probably been in existence for centuries. 
And the same phenomenon is discovered if we compare the rates of illegitimacy in different sections of Scotland since 1855 , when the first registration of these births was carried out. I shall refer to this hereafter in speaking of one great and most probable cause of the phenomena. It suffices to say now, that wherever in Scotland loose relationships were discovered to be frequent in 1855 and 1856 , there they are found to be frequent now ; and that wherever the rates of illegitimacy were then least, they are least to-day. Even from the first these discrepancies attracted attention, as a problem for which no solution seemed to present itself. Writing as far back as $185^{8}$, in the Report of the Registrar General, Dr. Stark says : "It would be a very interesting and instructive subject to inquire what are the peculiarities in manners and morals among the inhabitants of those counties where illegitimacy is so very high as compared with the manners and morals of those counties in which illegitimacy is low. That there must be some great differences no one can doubt when the results are seen so visibly as that one county regularly furnishes nearly twice the proportion of illegitimate births 
of the other." When these words were written this phenomenal regularity had been observed but three or four years, and it has since continued for more than thirty years.

What are the special causes of illegitimacy, especially of its widely different prevalence among communities and nations? We are justified, I have said, in assuming that such causes prevail. If all mankind were alike in temperament, disposition, preferences and habits, there could be no such manifest dissimilarity between different people as is now found in their regard for truthfulness, or their sense of honour : in their reverence for womanhood, regard for the rights of others, or the value placed upon human life. It is certainly a fair hypothesis of all that is abnormal in human conduct, which ascribes it, upon the whole, to variations in character, in organization and environment ; to the stress of temptation and the vitality of deterrent forces. Of course we cannot regard illegitimate births as a standard for anything like absolute measurement of moral delinquency. In some countries of Europe, marital infidelity may be far more frequent than in others, and coexist with a low 
ratio of births out of marriage. This is possible; yet the excuse can hardly be maintained as applicable to differences between the inhabitants of the same country, living precisely under the same civilizing environment. We cannot thus account for the contrast between Brittany and Normandy for instance, not to mention a hundred others. And so as between nations, the value of this theory - that the concealed sin on the one hand invariably counterbalances the notorious delinquency of the other-must be somewhat doubtful. It is not true that people are all alike, except in ability to conceal their vices. Differences in conduct absolutely and truly exist. Why? Why should one people be better or worse than another in this one respect? That is the problem before us.

Of the causes generally supposed to be the principal factors in the production of vice and crime,-Poverty, Ignorance, and the contaminations of great cities, stand among the first. Let us very briefly examine the potency of these as predisposing to the prevalence of illegitimacy. 


\section{Poverty.}

There can be no doubt that wealth, or at least a competence, does secure to its possessors certain safeguards against temptations, which assail not only the hungry and homeless, but those who are struggling for daily bread. The domestic servant has a poorer chance than the daughter of her mistress; the seamstress, bending over her needlework twelve hours a day, is not on an equality of temptation with those for whose pride and folly she wastes her life. It is therefore probable that in many cases the pinch of poverty does weaken the barriers against temptation. Charles Kingsley indeed has made the poacher's widow thus excuse her children's shame :-

"We quarrelled like brutes, and who wonders?

What self-respect could we keep Worse housed than your hacks and your pointers,

Worse fed than your hogs and your sheep?

"Our daughters, with base-born babies,

Have wandered away in their shame;

If your misses had slept, Squire, where they did,

Your daughters might do the same !"

And yet it is perfectly evident that poverty of itself does not predispose to vice or to looseness of morals. We hardly need statistics in 
proof of this, and yet they most potently confirm the general belief. If we look at those sections of the United Kingdom where poverty is most hopeless and pressure for the barest necessities of life the strongest, it is there, in very many instances, that we find the least tendency to illicit relations, so far as these are measurable by their most natural result. In Ireland, for example, we find the rate of bastardy is less than that in England or Scotland. Yet no one can question the misery in which the Irish peasantry has been steeped for centuries. But some parts of Ireland are exceptionally poverty stricken, and some sections, measured by an Irish standard, exceptionally prosperous. Two counties, Mayo and Down-one on the bleak and barren coast of the Atlantic, the other in prosperous Ulster, - each containing by the census of I88I about the same number of inhabitants, present a contrast which is worth a moment's special study.

Of the relative prosperity of the two sections we may obtain a fair idea through the Irish census of I88I. Four classes of dwelling houses were enumerated. Houses of the fourth class were defined as "built of mud or 
perishable materials, with only one room and one window;" homes, we may say, unfit for human habitation, and equalled only by the dwellings of the most barbaric tribes. The third class included houses of similar character but somewhat better built, of less perishable materials, and containing more than a single room or a single window. Houses somewhat superior to these constituted the remainder. Now in I88I in County Mayo more than threefourths of the population were enumerated as occupying dwellings of the third and fourth classes. In County Down scarcely one-third of the people were equally impoverished. In Mayo but little over one-eighth of its surface is susceptible even to cultivation, and forty per cent. is either barren or bog. From personal observation of many lands, I know of none where nature seems to have so strongly leagued with misrule to make prosperity impossible, as in Mayo, Ireland. In County Down, on the other hand, only eight per cent. of the land is intractable to the husbandman; and nearly half its total area is actually under tillage.

Now, how do these two sections of the same country differ in that sentiment of morality 
which at least tends to prevent illegitimate births? In order that the student may have opportunity to reach his own conclusions, the figures for ten years are given in the table below.

Table VII. - Comparison of Illegitimacy in two IRISH Counties (Down and Mayo) DURing io years, I 879-I888.

\begin{tabular}{l|r|r|r|r|r|r|r|r|r|r|r|r}
\hline & \multicolumn{8}{|c}{ No. of Illegitimate Births each year. } \\
\cline { 2 - 6 } County. & 1879 & 1880 & 1881 & 1882 & 1883 & 1884 & 1885 & 1886 & 1887 & 1888 & Total. \\
\hline Mayo & 31 & 51 & 29 & 34 & 33 & 28 & 36 & 23 & 30 & 27 & 322 \\
Down & 337 & 287 & 328 & 322 & 284 & 269 & 312 & 322 & 331 & 292 & 3084 \\
\hline
\end{tabular}

I have carried out these figures for so long a period that the reader may see that the phenomenal preponderance of bastardy in Down was persistent year after year. Compare now the proportion of these births to the total number born :-

\begin{tabular}{c|c|c|c}
\hline County. & $\begin{array}{c}\text { Total Births } \\
\text { ro years, } \\
\text { r879-88. }\end{array}$ & $\begin{array}{c}\text { Total Number } \\
\text { of } \\
\text { Illegitimate } \\
\text { Births. }\end{array}$ & $\begin{array}{c}\text { To I,00o } \\
\text { Total Births, } \\
\text { how many } \\
\text { illegitimate? }\end{array}$ \\
\hline $\begin{array}{c}\text { Mayo (Con- } \\
\text { naught). } \\
\text { Down (Ulster) }\end{array}$ & $\begin{array}{c}57,141 \\
60,346\end{array}$ & $\begin{array}{c}322 \\
3084\end{array}$ & $\begin{array}{c}5 \cdot 6 \\
51 \cdot 1\end{array}$ \\
\hline
\end{tabular}


What do these figures reveal? On the one hand we have a section of prosperous and happy Ulster, wherein the average rate of illegitimacy for ten years was $5^{\mathrm{I}}$ per thousand births, greater than that in England and Wales; while the wretched land of barrenness and bog shows a ratio less than any county in England, Scotland, or Ireland, and possibly less than elsewhere in Europe! If we look at the relation between illegitimate births and the unmarried and nubile womanhood between ages of 15 and 45 , we shall see a somewhat modified result, yet practically the same.

\begin{tabular}{l|c|c}
\hline & $\begin{array}{c}\text { No. of Un- } \\
\text { married Women } \\
\text { living between } \\
\text { ages of 15-45. }\end{array}$ & $\begin{array}{c}\text { To Io,000 Un- } \\
\text { married Women 15-45, } \\
\text { how many illegitimate } \\
\text { births annually during } \\
\text { ten years, I879-88? }\end{array}$ \\
\hline $\begin{array}{l}\text { Mayo (Connaught) } \\
\text { Down (Ulster). }\end{array}$ & 29,069 & 11 \\
ALL IRELAND. & 34,330 & 90 \\
\hline
\end{tabular}

I shall not at this point attempt any explanation of these figures, suggestive as they are to every thinker. They certainly do not imply that destitution, hunger, and chronic wretched- 
ness are provocative of immorality; although on the other hand it would perhaps be too great a stretch of scientific imagination to regard them as excitements to virtue.

The same fact I have observed in Scotland, in France, in Italy, in Switzerland, and it exists probably throughout Europe. Not that poor districts are invariable the most virtuous; they are not. But there is nowhere such uniform relation between the indigence of a people and the prevalence of illegitimacy, as to justify the hypothesis that this phrase of moral delinquency in any district or country can be accurately described as caused by its poverty.

II. Country and Town Life.

The wickedness of cities, and the virtues of rural populations, have been a theme for dramatists of every age. To some extent there is justification for the common belief. Crime, as a trade, best flourishes in centres of population; the professional burglar or thief seeks companionship in guilt amid the slums of a great city; the country girl "in trouble" would perhaps hide her shame in town. It may be doubted however, whether, in proportion to total population, the percentage of the vicious is so 
much greater in cities than in rural communities. Is the virtue of chastity far more highly prized by the peasant? It is not made evident by statistics. The great cities of England nearly all show a proportion of illegitimate births below the rate prevalent in certain agricultural and rural districts, inhabited by an honest, sober, industrious and estimable population. Contrast, for instance, the number of illegitimate in every thousand births as they occur in the three principal cities of England, with the rate which obtains in some of the most beautiful of rural resorts

Table VIII.-City and Country. To i,ooo Births, HOW MANY WERE ILLEGITIMATE?

\begin{tabular}{|c|c|c|c|c|c|c|c|}
\hline & 1885 & I886 & 1887 & 1888 & 1889 & 1890 & 1891 \\
\hline LONDON. & 40 & 38 & 40 & 38 & 38 & & \\
\hline BIRMINGHAM & 40 & 43 & 50 & 53 & 45 & & \\
\hline LIVERPOOL & 61 & $6_{1}$ & 66 & 57 & $5^{8}$ & & \\
\hline North Wales & 69 & 75 & 73 & 73 & $7 \mathrm{I}$ & & \\
\hline Westmoreland & 62 & 69 & 64 & 69 & 72 & & \\
\hline Cumberland & 75 & 79 & 72 & 78 & 79 & & \\
\hline Shropshire & $9 \mathrm{I}$ & 82 & $8 \mathbf{r}$ & 80 & 79 & & \\
\hline
\end{tabular}

It may be said that in large cities many such births escape registration and are put down as 
legitimate. This of course may be possible to some extent, but I should hardly think that it could account for these differences to any degree. For if the rate of bastardy in Shropshire or Cumberland was universal throughout England, it would mean an addition every year of thirty thousand illegitimate births to the total for England and Wales.

It is a singular fact that not only counties but far smaller sub-divisions of counties sometimes exhibit a perverse and violent tendency toward illegitimacy. The worst districts show a rate nearly double that of England and Wales. I was curious to ascertain how long this peculiar pre-eminence in bastardy had adhered to certain circumscribed localities ; and in the following table I give the average of five recent years (1884-1888) for the worst districts of England and Wales. It is interesting to compare the present condition of affairs with the tendency noted by the RegistrarGeneral, nearly half a century ago.

In regard to this table the reader will at once note several peculiarities. In every one of these rural districts the proportion of bastardy is exceedingly high, in nearly all of them more 
TABLE IX.-OF Eacil 1,000 BIRThS, HOW MaNy WERE Illegitimate in the Following Registration Districts of ENgland and Wales duRING PERIOdS MENTIONED BELOW?

\begin{tabular}{|c|c|c|c|}
\hline $\begin{array}{l}\text { Name of Registra- } \\
\text { tion District. }\end{array}$ & County. & $\begin{array}{c}\text { Annual Average } \\
\text { I } 88_{4}-1888 \\
\text { (5 years). }\end{array}$ & 1842 \\
\hline 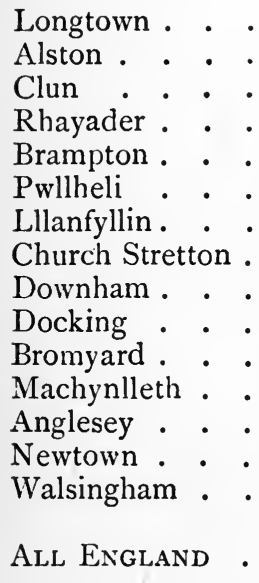 & 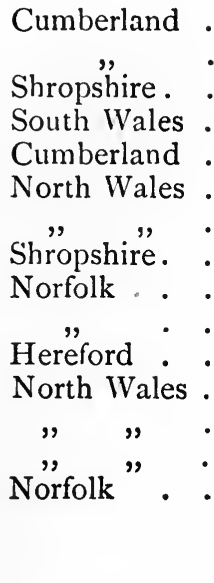 & $\begin{array}{r}\text { I } 77 \\
132 \\
122 \\
121 \\
\text { I } 17 \\
\text { I } 14 \\
\text { I03 } \\
98 \\
96 \\
96 \\
96 \\
93 \\
89 \\
95 \\
83\end{array}$ & $\begin{array}{r}172 \\
\text { I } 25 \\
109 \\
\text { I } 45 \\
\text { I } 72 \\
76 \\
80 \\
109 \\
86 \\
104 \\
125 \\
80 \\
78 \\
103 \\
104 \\
\\
67\end{array}$ \\
\hline
\end{tabular}

than double the rate of England as a whole. Half a century ago the rate of illegitimacy in every one of these districts was also higher, and in most cases far higher, than the average of the country at large. There are therefore certain sections of England and Wales where every sixth or seventh or eighth child is a 
bastard! Yet every one of these districts is at some distance from any great city. It is a curious fact that in three English counties adjoining each other, the rate of illegitimacy seems to increase in proportion to their distance from London, and this peculiarity goes back many years.

Table X.-To each I, 000 Births, how many Were ILLEGITIMATE?

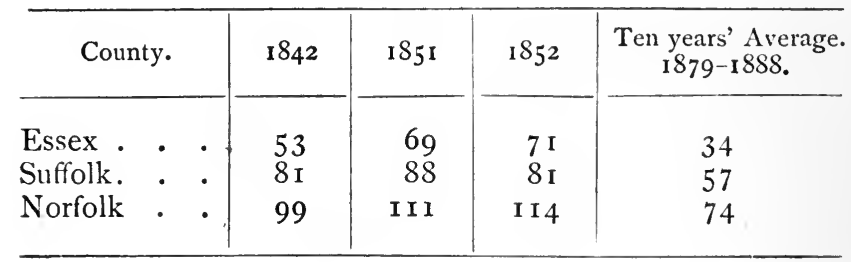

Is rural life then favourable to these illicit relationships? One can hardly affirm this at present. There may be a tendency to change of residence by young women in trouble from cities to their country homes, or from rural neighbourhoods to the city streets. How far these counterbalance each other one cannot say. Probably the equilibrum is not much disturbed either way, since changes of habitation are impossible to the great mass of the lower orders. In large towns there is possibly more 
of vice and dissipation than in the country; at all events it is there more concentrated and obvious. The statistics I have gathered certainly would indicate that a singularly lax theory of sexual morality obtains in some of the most secluded and remote districts of England, Scotland and Wales. One little district where for many years about one in every seven children was born illegitimate, ${ }^{1}$ rejoices in perhaps the longest and most unfamiliar name in Great Britain-Llanfihangelytraethau. If the same rate of illegitimacy obtained throughout England as is maintained annually in this sylvan retreat, the number of such births in this country would be increased by more than 75,000 every year!

III. Influence of Education.

What influence upon moral sentiment can we ascribe to the general diffusion of secular education? A generation ago the theory that ignorance was the great cause of vice and crime became an accepted axiom. Statistics were pressed into service; it was shown that the majority of

${ }^{1}$ The rate of illegitimacy in this district during five years (1884-1888) was almost exactly I 33 per thousand; three times that of England and Wales. 
criminals could not read or write; and this educational defect was assumed to be, in a great measure, the cause of their tendency towards vicious and depraved livelihood. To some slight extent the theory may possibly have been correct; but so far as illegitimacy is concerned, I doubt if we can detect any certàin deterrent influence in rudimentary education. Districts or countries where a high standard of elementary education prevails do not appear to maintain any marked pre-eminence of morals above their more ignorant neighbours. If the theory were true which ascribes a moral influence to secular learning, then in every land where the ability to read and write is most widely possessed, we should expect to find a decreased rate of bastardy as compared with nations where popular education has made no headway.

But the facts generally are most absolutely opposed to this hypothesis. If we study the map of Europe, we find that many countries where popular education is widely diffused among all classes, such as Denmark, Norway and Sweden, Prussia, Saxony, and Scotland, show a high rate of illegitimacy, while in some 
others, such as Russia and Ireland, the rate is very low. Even in the same country, and under the same laws, we do not find that virtue and the spelling book are invariably associated. Many years ago it was observed that in Scotland "the counties which show the highest proportion of illegitimacy are the counties which are in the highest condition as to education; while, on the other hand, the counties which produce the fewest illegitimate births are those where education is at the lowest ebb." 1 That was written nearly thirty years ago, but no change in the annual phenomenon has been since observed. Take one curious instance. Of the number of women married in Kirkcudbright, a county in southern Scotland, 99 per cent. are able to write their names in the marriage register; showing a larger proportion of women thus far educated than in any country of Europe or any county of England or Wales. Yet the rate of bastardy which there annually prevails is, year by year, greater than in any one of the 89 departments of France, Paris only excepted! This is not a solitary instance.

1 See Reg. Gen. Report for Scotland, for the year 1862. 
During the ten year period, $1879-1888$, there was not a single year in which the rate of illegitimacy was not four times as high in Ulster as in Connaught; yet in which province is education more general? In France, putting Paris aside, those departments where ignorance of the alphabet is most general, are in many cases the very ones which hold the virtue of chastity in highest esteem. Finisterre for example, of the 89 departments of France, stands first for the ignorance of the male population and first for the illiteracy of its women; yet its rate of illegitimacy during the period observed was but 34 per I,000 births; less than that which prevailed during the same time in any one of the counties of England, Wales, or Scotland.

We have now passed in rapid review some of the imputed causes of this departure from social morality, and tested by the evidence of facts they fail to account for the different moral standards which in different localities tend to prevail. We cannot ascribe this laxity of conduct to poverty, since it least manifests itself where destitution and want have fixed their strongest hold. The absence of secular education is not a sufficient cause. In the great centres of 
commerce and manufacture it has not such rate of prevalence as we observe "far from the madding crowd" in the secluded villages of the Lake Country, or among the hills of Wales. What then are the causes? Surely it is no blind Fate which has thus cursed the Saxon, the Swede, and the Dane; it is no peculiar "predestination" to evil-doing that gives to Scotland its unfortunate pre-eminence. Some agencies are continually at play to create that divergence which never fails to excite the wonder of the student while contemplating the record of facts. And while I cannot claim that the evidence suffices to make doubt no longer possible, it seems to me that the wide and apparently irreconcilable differences which exist in regard to the local prevalence of illegitimacy, may be ascribed, with so strong degree of presumption in their favour as to make it "a working hypothesis," chiefly to three great causes. These are :-

I. Religion.

II. Legislation, and legal impediments to marriage.

III. Heredity, or the influence of race and ancestry. 
I. Religion.

The effect of religious belief upon human conduct is beyond question. At every age of the world's history it has influenced legislation, incited or repressed warfare, and tended on the whole to solidify and crystallise the best elements of advancing civilization. As I propose hereafter to treat the larger question of its influence as a restraint against vice and crime, it is, perhaps, needless now to anticipate the argument there to be advanced, or the conclusion to be reached. But some reference must be made to one of the most potent of agencies in checking the passions and proclivities of the human animal.

Granting its immense force upon human conscience, in the abstract, does its power depend in any sense upon the truth of its dogmatic teaching? At first glance there seems to be no question about it. Nearly every one who may read these pages is convinced that his own particular system of belief is the true basis of a sound morality: that the world would be all the better if they could adopt his creed; and that to the unsound theology of corrupt systems of faith we must ascribe the moral 
failure of a wicked world. Is this overstated? Is there any reader who admits that another system of belief than the one he cherishes would make him a better man?

It may be of interest for the student-whatever his religious faith may be-to test for himself, by reference to the tabulated statements he may find in these pages, the question of relationship between a true creed and that conduct which should be its invariable result. Does he believe, for instance, that the highest appreciation of chastity depends upon the spiritual acceptance of Calvinistic theology; in reverence for the sanctity of the Sabbath, and abhorrence of the Papacy? Let him ponder over the statistics of Scotland, and explain why this land of strictest Sabbath keeping and purest Calvinism exhibits double the illegitimacy of England every year. Does he hold that the pre-eminent excellence of the theology of Martin Luther is evidenced by the morality of its believers? Let him study the records of Norway, Sweden, and Denmark, where Lutheranism for centuries has held undivided sway. Does he claim that the infallible creed of the Roman Catholic Church insures its ad- 
herents superiority in morals? Then upon this hypothesis he must explain why Austria and Bavaria are so low down on this scale. Is it, then, to believers in the thirty-nine articles of the Established Church of England that we are driven to look for freedom from frailty? But where in England is the rate of illegitimacy so low as in Russia or in Greece,- - not to speak of Ireland at her side?

In the face of paradoxes like these it would seem almost a contradiction of terms to assert Religion as one of the great efficient forces regulating and controlling the conduct of human passion. We know that its effect is infinitely great in individual cases; how then, we ask, does each phase of faith seem in certain instances to lose its hold? In another work the question will be discussed and a solution suggested. That in every age the religious sentiment of humanity has exerted a very powerful influence upon conduct cannot be questioned; although it may be doubted how far this influence, so far as the great seething mass of human beings are concerned, is not generally subordinate to the other and even stronger forces that move humanity toward action. 


\section{Legislation.}

A favourite maxim with a certain school of writers is that the State cannot make men moral by Act of Parliament. So far as this apophthegm is intended to imply that legislation cannot and does not influence conduct for right or wrong, it is contradicted by universal experience. In every instance it is the State that makes of an act a crime. As I write, a member of the House of Commons expelled from Parliament, is undergoing a term of imprisonment for an act which he might have done with impunity up to a few years ago. Then, the English conscience being aroused, Parliament made a new crime. Poaching, for instance, is wrong in England, but not in America; the law of the land makes the offence. A blind man begging on the steps of St. Paul's in London would be taken into custody as a vagabond; before the Church of the Holy Sepulchre in Jerusalem, or of St. Peter's in Rome, he receives his tribute of coppers, and commits no offence. It is equally within the power of the Sitate to erase from its statute book every distinction of birth ; to make all children legitimate. , It is possible, because 
it has been done. Two sovereigns that once occupied the throne of England, daughters of Henry VIII., were both illegitimate as far as the law could make them, but by the first Act of her reign, Mary hastened to erase the stigma against herself. Lord Kames tells us that in 1707, Iceland having become almost depopulated by an epidemic, the King of Denmark issued a proclamation, making legitimate all children born thereafter in the island, to this extent, that no unmarried mother was to be deemed to have lost her reputation until her progeny exceeded six! The effect may be imagined.

While in Utah some years since, a lady showed me a photograph of a large group of girls about the same age. At first glance I took them to be classmates of a school. "They are some of my husband's daughters," she explained, "the three at the right are my own." Custom, religion and local laws, made them then and there legitimate children.

In what way does legislation influence the rate of illegitimacy? I think we may say in the first place-that every impediment to marriuge tends to increase illicit relationships. It does 
not at all follow that these restrictions are unwise, or should be abolished. In Bavaria, at one time, no young man was permitted to marry until he could prove reasonable ability to support a family; and Bavaria, twenty-four years ago, stood first in Europe for the proportionate number of its illegitimate births. In various European countries the young man must not marry until he has completed his military service. In France, consent of parents is a legal necessity up to a certain time. In all countries legal marriage costs money, not much, but yet something; and a growing inclination is everywhere noticed among the working classes of the Continent to dispense with all ceremonies and simply go to house-keeping. Dr. Bertillon has estimated that in Paris there are probably no less than 80,000 homes where the parents are living in harmony, and educating their children, married in every sense of the word, except that they refuse to obtain the sanction of either Church or State. But their children are illegitimate. In Italy, another and very sad phase of illegitimacy is the result of the present struggle between Church and State. To the pious Catholic, marriage is a sacrament 
which needs no sanction from human government to make it valid. But in the eye of the law marriage is simply a civil registration, without which no sacraments or ceremonies of religion can make cohabitation other than illegal. Unfortunately, hundreds of poor girls have relied solely on their religious marriage, only to find themselves mothers of bastard children whose legal rights the law cannot acknowledge. ${ }^{1}$ Yet the State is quite within its rights in demanding civil registration as a needful adjunct to religious ceremony. The trouble is that in Italy the Church is at war with the State.

In England too, the law makes relationships illegitimate, which are perfectly regular in other parts of the English-speaking world. Children of a deceased wife's sister are bastards in England, yet legitimate everywhere else in Australia, in Canada, and in the United States. In some communities the tendency is to make all sexual relationships legitimate, if no legal impediment exists. N No ceremony of any kind whatever, civil or religious, is necessary to constitute a legal marriage in the State of New

1 See the "Story of Ida," with introduction by Juhn Ruskin. 
York. If two parties, living together, speak of each other as husband and wife, this public acknowledgment is all that is requisite to constitute their relation in the eyes of the law, a perfectly valid marriage, always supposing that there be no previous relationship of the kind. Yet children born from such a union, and legitimate in New York, are counted as bastards by every nation of Europe. The State is here supreme, and the wish of the people is the State.

I think it perfectly evident that if throughout Europe all obstacles to marriage were abolished; if parental prudence were given no power to oppose; if all that is necessary were simply the registration of intention before a public official qualified to take acknowledgments, an act of recognition obtainable at all times, publicly or privately, by rich or poor, without fee or cost of any kind, it would undoubtedly add to the greater frequency of the legal tie among the poorer class, and decrease in very great proportion the prevalence of illegitimate births.

To what extent is illegitimacy increased or modified by the legal opportunity which in 
some countries exists of proving paternity and legitimizing the offspring? The two things are not the same. England permits the search for the putative paternity, but refuses to admit the bar sinister ever to be rubbed out. In Scotland, on the contrary, marriage of the parents makes a bastard legitimate. Does this possibility of reparation lead to greater frequency of ante-marital faults? Possibly, to some extent, though I should doubt if it had so much influence as is often supposed. This reparation by marriage can be nearly always made before the child is born; and if not made during pregnancy in spite of all pleading, the chance of its being made afterwards must be so slight that its influence I should think would be equally insignificant.

Somewhat otherwise must be the effect of refusing or permitting to a girl-mother any legal right of imputing the paternity of her offspring. In the majority of countries of Europe this inquiry may be made; in a few, it is entirely refused, and the mother must expect to bear the burden and responsibility for herself. The certainty that the father of her child need never be called upon for the least assistance would 
naturally, we should think, influence hesitation. Doubtless it does to some extent, but the influence is far from producing uniformity, and cannot be very strong. Compare, for instance, the prevalent rate of illegitimacy in countries permitting or refusing this right of inquiry.

Table XI.-To I,000 Children Born, how many WERE ILlegitimate DURING THE PERIOD OF Five YeARS (I878-82)? Stillbirths NOT INCluded.

\begin{tabular}{|c|c|c|c|}
\hline $\begin{array}{l}\text { Countries where in- } \\
\text { quiry as to paternity } \\
\text { is refused. }\end{array}$ & $\begin{array}{l}\text { Rate to } \\
\text { I,000 } \\
\text { Births. }\end{array}$ & $\begin{array}{l}\text { Countries where in- } \\
\text { quiry as to paternity } \\
\text { is allowed. }\end{array}$ & $\begin{array}{l}\text { Rate to } \\
\text { I, oco } \\
\text { Births. }\end{array}$ \\
\hline $\begin{array}{lccc}\text { Belgium } & \cdot & \cdot & \cdot \\
\text { France } & \cdot & \cdot & \cdot \\
\text { Italy } & \cdot & \cdot & \cdot \\
\text { Holland } & \cdot & \cdot & \cdot \\
\text { Russia. } & \cdot & \cdot & \cdot\end{array}$ & $\begin{array}{l}77 \\
74 \\
73 \\
30 \\
28\end{array}$ & 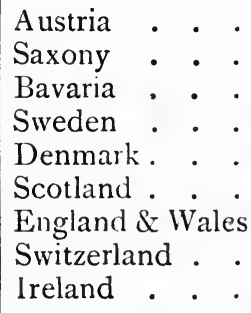 & $\begin{array}{r}\text { I } 43 \\
\text { I } 27 \\
\text { I } 32 \\
\text { IO I } \\
\text { IOI } \\
84 \\
48 \\
47 \\
25\end{array}$ \\
\hline
\end{tabular}

It is probable that certain forces here neutralise each other.

The highest rates of illegitimacy are certainly found where research for paternity is allowed; but then also and in the same group, are countries whose rate is exceedingly low. The 
refusal seems almost a gratuitous cruelty, even if it be like capital punishment in cases of theft - somewhat of a deterrent.

\section{Heredity.}

But of all causes of human conduct, one of the most potent is probably the predisposition that lies wrapped in organization, and which is passed onward by inheritance. That races as well as individuals differ in mental and moral tendencies as well as in physical characteristics, seems to have been recognised from the dawn of history. The earliest conquerors of neighbouring or distant tribes must have noted that one clan was war-like, another timid and treacherous; one people easy to bring under subjection, another impatient of restraint and quick to rebel. There appears thus to be a tendency in human nature for propensities and virtues to become crystallized, and for proclivities, active for generations, to become in some way fixed elements of character and physique. It is a trite saying that "civilization is but a thin crust over innate barbarism ;" and now and then the world stands aghast when this savage love of cruelty, this hereditary viciousness breaks through all re- 
straints, and the savage stands revealed to himself. No two nations of Europe-probably no two nations in the world-are alike in love of decency, in appreciation of virtue, in proclivities to vicious indulgence, or in subjection to moral and religious restraints. That one may see how complete is this difference, I have drawn up the following table from the facts presented by Dr. J. Bertillon, but re-arranged in order of least prevalence of illegitimate births, during the period named, to the total number of children born. (See next page.)

If these peculiar differences were unevenly fluctuating from year to year, it would be impossible to explain them on the hypothesis of heredity. But the phenomena is persistent. It has existed as far back as accurate facts have been at our disposal. Changes are going on ; in some nations the rate is possibly rising, in others it is certainly falling. The progress in either direction, measured by single years, is comparatively slow.

It will be noted that, with few exceptions, the Northern nations of Europe of Scandinavian or Teutonic origin, apparently show the strongest proclivity to those ante-marital irregularities of 
TAble XII.-.-Comparison OF Illegitimate Births among principal Nations of Europe (Five Years, I878-I 882$){ }^{1}$

\begin{tabular}{|c|c|c|c|c|}
\hline Country & & $\begin{array}{l}\text { Prevailing } \\
\text { Religion. }\end{array}$ & $\begin{array}{c}\text { To I,O0o } \\
\text { Births how } \\
\text { many were } \\
\text { illegitimate. }\end{array}$ & $\begin{array}{l}\text { To each 1o,000 } \\
\text { women un- } \\
\text { married over 1 } 5 \text {, } \\
\text { how many ille- } \\
\text { gitimate births } \\
\text { per year. }\end{array}$ \\
\hline $\begin{array}{l}\text { Ireland } \\
\text { Russia }\end{array}$ & $:$ & $\begin{array}{l}\text { Roman Catholic } \\
\text { Greek }\end{array}$ & $\begin{array}{l}25 \\
28\end{array}$ & $3^{I}$ \\
\hline Holland . & $\cdot \cdot$ & $\left\{\begin{array}{c}\text { Twoo-thirds } \\
\text { Protestant }\end{array}\right\}$ & 30 & 66 \\
\hline Switzerlan & & $\left\{\begin{array}{l}\text { Nearly equally' } \\
\text { divided }\end{array}\right\}$ & 47 & 74 \\
\hline $\begin{array}{r}\text { England } \\
\text { Wales }\end{array}$ & $\begin{array}{l}\text { and } \\
. \quad .\end{array}$ & Protestant & 48 & 103 \\
\hline Italy . & . & Roman Catholic & 73 & I69 \\
\hline France & . . & $" \quad$, & 74 & 109 \\
\hline Belgium . & . . & ," & 77 & I39 \\
\hline Prussia . & .. & Lutheran & 77 & 182 \\
\hline Norway . & . . & & 82 & 146 \\
\hline Scotland. & . . & Calninism & 84 & I 5 I \\
\hline $\begin{array}{l}\text { German } \\
\text { Empire }\end{array}$ & & $\left.\begin{array}{c}\text { Two-thirds Pro. } \\
\text { testant }\end{array}\right\}$ & 89 & 206 \\
\hline Denmark. & & Lutheran & IOI & 203 \\
\hline Sweden & . . & ", & IOI & $15^{8}$ \\
\hline Saxony & & , $96 \%$ & 127 & 343 \\
\hline Bavaria . & • & Roman Catholic & I 32 & 295 \\
\hline Austria . & $\cdot \cdot$ & $" \quad$ " & I 43 & 330 \\
\hline
\end{tabular}

1 For the averages of this table I am indebted to the paper of Dr. Jacques Bertillon, read before the International Congress of Hygiene and Demography, at Vienna. 
which illegitimacy is a sort of gauge. Why should it be so prevalent in Norway, Scotland, Iceland, Sweden, Finland, Denmark, Prussia, Saxony, Austria and Bavaria? Why does Holland stand almost alone on the Continent? We cannot ascribe it to her religion, for look at Saxony! We are dealing here not with wornout or effete civilizations, nor with peoples given over to mad indulgence, and blind to all restraints. I venture to believe that partly in local customs, partly in existence of impediments to early marriages, partly to causes connected with religion, but most of all to the inheritance of Race and the proclivities of immediate ancestry we must look for any satisfactory explanation of these curious differences. Of course it needs constantly to be borne in mind that the rate of illegitimacy is no standard whatever of upper-class morals, and that in some countries an immense amount of marital infidelity occurs, yet leaves nothing for the statistician to record. But everywhere, too, the upper and prosperous classes are less in number than the great mass of the people, and regarding these, it is a tolerably fair exponent.

Chiefly upon hereditary predisposition or 
organization, persistent through successive generations of families, I am inclined to ascribe in great measure that most remarkable phenomenon to which allusion has been made; I mean the persistent and wide difference in moral stamina apparent in sections of the same country. It is a tenet of the national faith, that the morals of an average Englishman are better than those-let us say, of a Neapolitan or a Turk; but what of differences between North and South England, or between East Anglia and Wessex? They are all English, influenced by the same religion, governed by the same code of laws; why then do they differ? Dr. Jacques Bertillon has pointed out that a line drawn on the map of France between Normandy and Brittany, and running south-easterly to Lyons and Geneva, very accurately divides those departments of France where illegitimacy is largely prevalent from those where it is comparatively rare; and singularly, this is also a line of demarcation between the races that are supposed to have intermingled in the blood of the Frenchman of to-day. Now it has been suggested by high authority that the different degrees of moral susceptibility in this respect 
which we discover in England to-day may be due to heredity; to the different strains of English blood, making themselves felt in individual conduct even after a thousand years of unity as a nation. Sir George Graham, writing many years ago, first pointed out in a paragraph that I have never seen quoted, this singular correspondence. "Excluding London," he says, "it may be inferred that generally the unmarried women in the counties south of the Thames, comprising the descendants of the old Saxon population, have few illegitimate children; Wales stands next in the scale ; the West Midland, the N.W, and the South-Midland counties, covering the area of ancient Mercia, present less favourable results; while in Yorkshire, the Northern counties and the North Midland counties, covering the area of the ancient Danish population, the number of illegitimate children is excessively great. $^{1}$ "

This is undoubtedly a bold hypothesis. We are accustomed to think of English blood as homogeneous and intermingled by this time; and to expect to trace certain influences to

1 I 4th Annual Report of the Registrar General, p. I3. 
Danish blood a dozen centuries after the Danish invasion seems improbable enough. I am by no means disposed to account for all the divergence between North and South England by this theory; yet the hypothesis possesses one remarkable advantage: it explains phenomena otherwise inexplicable.

Every student of English history is aware of the multitudinous origin of this English race: the Celt, the Roman, Angles, Jutes, Saxons, Danes, and Normans, each has stamped his impress on our features, or infused within our commingled blood some specialisation of character, some tendency towards virtue or vice. But granting this, it by no means follows that the commingling has been everywhere equal or uniform. For centuries, the great mass of the people in any locality must have been fixed to the soil by their poverty and occupation, almost as absolutely as the serfs of Russia before their emancipation. Travel was beyond their means, and the necessity for daily bread must have kept them steadily to their daily tasks. It seems very probable that the admixture of race, upon which we lay so much stress, may indeed have been far less than we 
have supposed among the greater mass of the people. The working-class population of Norfolk or Yorkshire for example, may very probably have exceedingly little intermixture of the blood that pervades the Englishry of Cornwall or Somerset. They differ, not merely in dialect-which tells its own story-but in ancestry, in history ; and while some commingling of all races has undoubtedly occurred among the wealthier and more privileged classes, it has not been sufficient very greatly to disturb the inherent tendencies and characteristics of each particular tribe.

But can these ancestral proclivities announce themselves in the conduct of to-day? It is quite conceivable, I think, without any great violence to probability. Suppose, for instance, that a thousand years ago, upon part of the English coast-not then England-there descends a horde of piratical adventurers. They delight in blood and warfare; they toss the captive infants from spear to spear; they have no regard for chastity - indeed, they have little reverence for any religious constraints whatever. ${ }^{1}$ They take possession of the land, en-

"Bede tells us how the Saxons fastened on Essex, 
slave the conquered, and become gradually, after a few generations, fixed to the soil. ${ }^{1}$

Now it is quite within bounds of possibility that from the first conquest, bastardy may have been regarded among the people of such a tribe with much greater lenience than by another and more civilised tribe; that the stigma should be less, and the chance of complete reparation of character by marriage be always more probable. Every neighbourhood of such a community for generation after generation would contain a certain large proportion of the illegiti-

Surrey, and Wessex; how the Angles coming from Anglen (the true old England) founded the mighty kingdoms of East Anglia, Mercia, and Northumbria. Fearful must have been the woes undergone by the Celts at the hands of the ruthless English heathen, men of blood and iron. The few Celtic words admitted to the right to English citizenship . . . seem to show that the Celtic women were kept as slaves, while their husbands, the old owners of the land, were slaughtered in heaps."-Oliphant's "Old and Middle English," p. I9.

1 Mr. Green, in his "Conquest of England," tells of these warriors who "drove mothers to slavery, and tossed babes in grim sport from pike to pike." One of our conquerors, indeed, was specially nicknamed by his companions because he absolutely refused to join in the sport of tossing children on pikes.-Green's " Conquest of England," p. 55 . 
mately born ; laxity of morals, as we understand the phrase, becomes evidenced by frequent events; the custom is an inheritance of proclivity, and an example that is too common to deter. Let this state of affairs go on for centuries, unnoticed by any comparison with other localities, now increased by wars and rebellions, now lessened a little, let us hope, by the precepts and influence of the Church; and when, after a thousand years, science through statistics looks at last at the very heart and life of a nation's morality, it might expect to discover in localities, subject for centuries to such influences, and among people of such an origin, an especially high rate of illegitimate births. That something like this has happened is at least probable. One tribe of our common ancestors were pirates, and piracy was never provocative of domestic virtue.

Quite as curious, and even more vivid in some respects, is the picture which is presented by the statistics of Scotland for the last thirtyfive years, and to which I have before referred. When the first detailed report of the Registrar General for the year I855 was published, it appears at once to have attracted attention. 
Certain counties of Scotland were found to present then a higher proportion of illegitimate births than in any part of France-Paris only excepted. They have maintained this singular pre-eminence ever since. Not only that, but this peculiar tendency toward loose and illicit relationships seems confined to certain counties and groups of counties - which we might almost call infected districts, so distinctly are they marked off from other sections of the country. Let us study one of them.

The counties into which Scotland is subdivided may be grouped together according to their geographical situation. One of these sections, a little cluster of five counties in the Highlands, honoured by the residence of royalty and enlightened by a University, is known to the Registrar General as the North-Eastern District. Rivalled only by the southern counties which border on England, this North-Eastern group stands above all other parts of Scotland for its ratio of illegitimate births. See, for instance, how uniformly this district has maintained its peculiar prominence for many years, when compared with another group of counties lying side by side. 
Table XIII.-Scotland: Of each i,o00 Births, how MANY WERE ILLEGITIMATE?

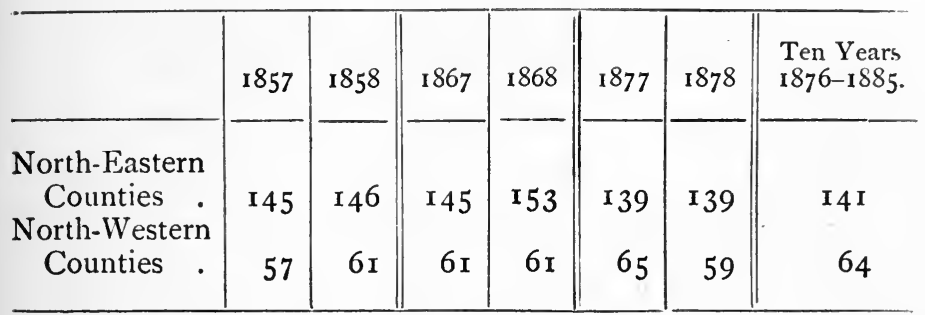

There was no country in Europe, which in 1877 and 1878 exhibited the proportion of illegimate births prevailing in North-Eastern Scotland, with the sole exception of Austria, where the rate was 140 in the last-named year. If the reader cares to consult a map of Scotland he will see no special reason why such differences should exist. The North-Western district is composed of Ross, Cromartie, and Inverness. The North-Eastern district comprises the counties of Banff, Elgin, Nairn, Kincardine, and Aberdeen; the five forming a promontory jutting out toward Scandinavia.

Now why do these two sections differ, and differ so enormously? Why does one locality persistently and regularly pay twice the tribute of bastardy of its neighbour, year after year, 
decade after decade-possibly century after century?

It is not due to ignorance, for as recently as I 878 , it was found that in this North-Eastern division only 6 per cent. of the women who married were unable to write, while in the 'North-Western' region the females were so ignorant that only 38 per cent. of the whole number who married could sign their names. It is not due to poverty, for there was in no part of Scotland so small a percentage of the population living in cottages of a single room. It cannot be due to religion, for they both cherish the same stern faith of Calvin and Knox. It is not caused by any surplus of women, as some have suggested, for between the ages of fifteen to forty-five, there is a larger proportion of unmarried females in other parts of Scotland where illegitimacy is far less. Nor is it due to any centralised predominance of vicious tendency in any one part of this promontory. On the contrary, the general proclivity seems to diffuse itself over the entire region with great evenness of distribution. Compare, for example, the rate of illegitimacy in the different counties of which this district is composed. 


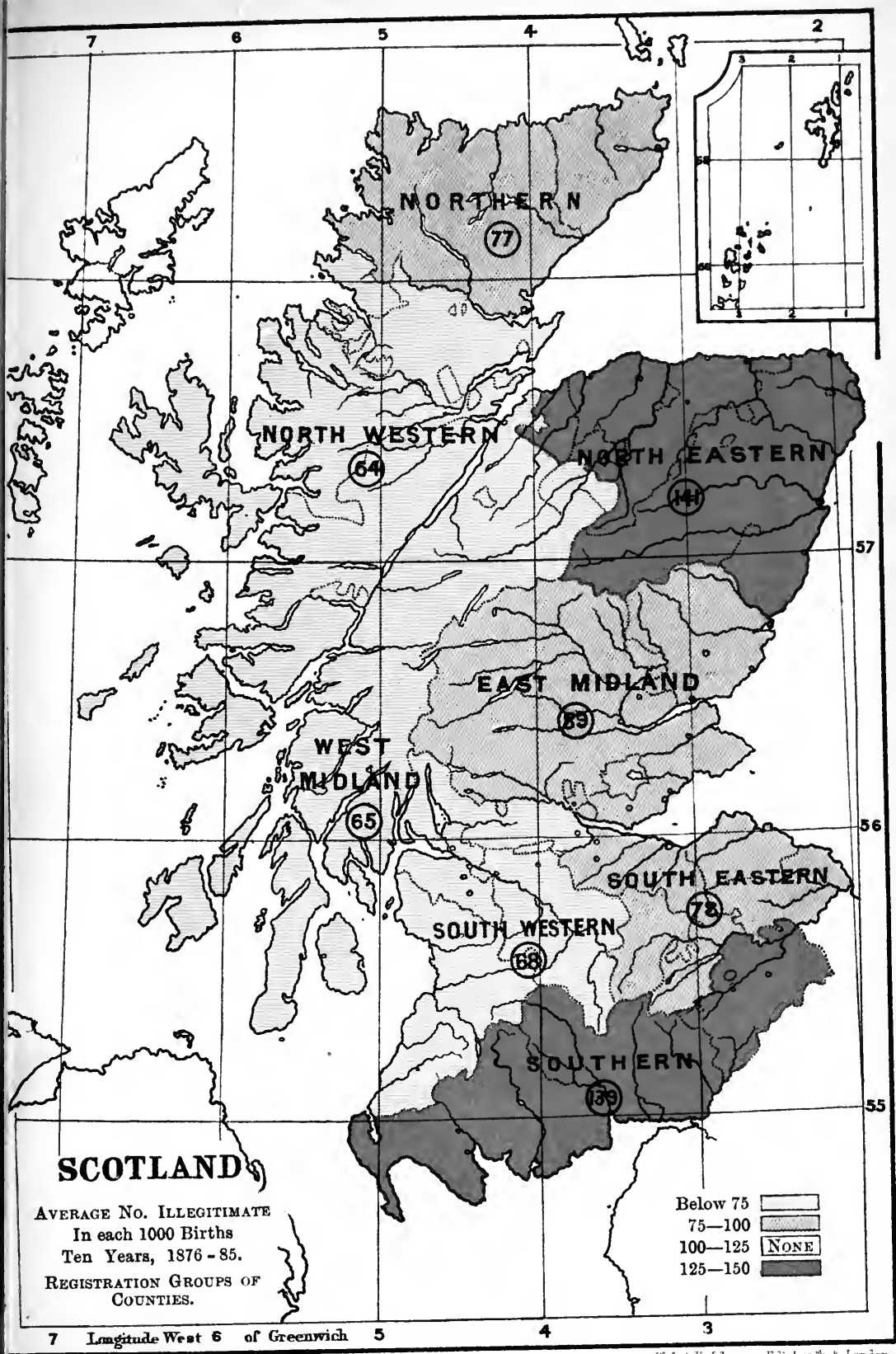


TABLE XIV.-To I,OOO BIRTHS IN EACH OF THE FOLlowing Counties in North-Eastern Scotland, HOW MANY WERE ILLEGITIMATE?

\begin{tabular}{|c|c|c|c|c|c|}
\hline $\begin{array}{c}\text { Scotland, } \\
\text { N.-E. District. }\end{array}$ & 1858. & $\begin{array}{l}\text { Average of } \\
\text { Ten Y ears, } \\
\text { 1 } 876-1885\end{array}$ & 1886. & 1887. & I 893. \\
\hline 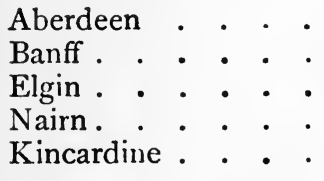 & $\begin{array}{r}158 \\
160 \\
116 \\
89 \\
\text { I30 }\end{array}$ & $\begin{array}{l}137 \\
164 \\
153 \\
106 \\
125\end{array}$ & $\begin{array}{l}\text { I42 } \\
\text { I62 } \\
\text { I } 49 \\
\text { 146 } \\
\text { I } 23\end{array}$ & $\begin{array}{r}\text { I35 } \\
\text { I65 } \\
\text { I } 49 \\
94 \\
\text { I } 24\end{array}$ & \\
\hline 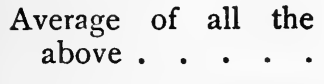 & I 46 & I4I & I 44 & I37 & \\
\hline
\end{tabular}

Little or no amelioration in its tendency toward illicit relationships has taken place in these counties since the facts were first discovered. One in seven,-that was its tribute to bastardy in 1858 , and that tribute it pays to-day. It seem to me that the most plausible explanation of this remarkable local proclivity toward immorality is, that it is primarily due to ancestral tendencies, coming, it may be, from pre-historic times. Probably the immediate and active cause to-day is the contagion of loose example, the near inheritance of unwise proclivity. The subject of illegitimacy in Scotland deserves a special study, occurring as it 
does in a country distinguished above every other in Europe ${ }^{1}$ by its zeal for orthodox belief.

Evidence of hereditary proclivity in this respect is not wanting in other lands. The islands of the Pacific have for the most part become converted to Christianity; but travellers do not report the existence among the islanders of any very rigid rules of chastity. The negro, transplanted from his native barbarism to America, Christianized, educated, and given the rights and privileges of citizenship, retains as a race, it would seem, nearly all the vicious and lascivious propensities of his forefathers in the jungles of Africa. The rate of illegitimacy prevailing in the American capital is three times that of London; but this is almost entirely due to the coloured population.

Where statistics are so absolutely wanting as in most parts of America it is not satisfactory to make deductions, ${ }^{2}$ yet the opinion of those

1 Those interested in the geographical distribution of illegitimacy will find in the Appendix several tables of interest, not elsewhere to be found out of Official Reports.

2 Writing in 1845 , Sir G. Graham, the Registrar General, said: "The United States in respect to Statistics of health 
who have studied the condition of the Free South is decidedly unfavourable to the standard of female chastity which prevails among the coloured population throughout the Southern States,-even after nearly thirty years of emancipation and the rights of free citizenship. Everywhere the same story can be read, wherever different races are living under one flag. Sicilian and Lombard are Italians, Breton and Norman are French, but there is somefar deeper than the bond of a common language, or a mutual attachment to the same form of government. Indeed I know of few studies of more absorbing interest than the tracing out through the statistics of vice and crime, of insanity and suicide, the workings of destiny through natural laws, and the influence of ancestral vices and virtues upon character and conduct in humanity to-day.

A few other points deserve passing mention,

and human life is on nearly the same footing as Asia and Africa." This criticism is at present not quite fair ; for as regards Japan, there are better vital statistics obtainable to-day than for the United States of America, where the only record of vital statistics for the entire country is made but once in ten years. 
although they are of more interest to the student of moral pathology than to the general reader.

1. At what age are young women most apt to fall into relations which make illegitimate births possible?

Only two countries-Denmark and Sweden -afford any facilities for a scientific reply to this question. It is unlikely that their experience corresponds precisely with that of other nations; and certainly the reply they afford is quite contrary to what we should expect.

Table XV.-To I,O00 Unmarried Women at each PERIod OF LIFE, how MaNy Illegitimate ChildBIRTHS PER YEAR?

\begin{tabular}{|c|c|c|c|c|c|c|c|c|}
\hline \multirow{2}{*}{ Country. } & \multicolumn{8}{|c|}{ Age of the mothers at birth of the illegitimate children. } \\
\hline & $x_{5}-$ & $20-$ & $25-$ & $30-$ & $35-$ & $40-$ & $45-$ & All ages together. \\
\hline $\left.\begin{array}{cr}\text { Sweden. } & \text { Towns } \\
,, & \text { Rural } \\
& \text { Districts }\end{array}\right\}$ & $\begin{array}{l}7 \\
3\end{array}$ & $\begin{array}{l}51 \\
26\end{array}$ & $\begin{array}{l}7 I \\
4 I\end{array}$ & $\begin{array}{l}62 \\
39\end{array}$ & $\begin{array}{l}4 I \\
29\end{array}$ & $\begin{array}{l}17 \\
\text { I3 }\end{array}$ & $\begin{array}{l}\text { I } \\
\text { I }\end{array}$ & $\begin{array}{l}39 \\
19\end{array}$ \\
\hline $\left.\begin{array}{c}\text { DENMARK. Towns }{ }^{1} \\
\bullet, \quad \text { Rural } \\
\end{array}\right\}$ & $\begin{array}{l}6 \\
6\end{array}$ & $\begin{array}{l}33 \\
39\end{array}$ & $\begin{array}{l}52 \\
58\end{array}$ & $\begin{array}{l}47 \\
47\end{array}$ & $\begin{array}{l}31 \\
33\end{array}$ & $\begin{array}{l}14 \\
15\end{array}$ & $\begin{array}{l}\text { I } \\
\text { I }\end{array}$ & $\begin{array}{l}27 \\
29\end{array}$ \\
\hline
\end{tabular}

1 Exclusive of Copenhagen.

It will be seen at once that, so far as Den- 
mark and Sweden are concerned, the greatest liability for such births is not early in the life of unmarried womanhood; but between twentyfive and thirty-five years. Even after the age of forty it is higher than under twenty! But these figures are insufficient for any safe deductions as regards other countries of Europe; for while it is possible that elsewhere there obtains this same phenomenon of increased illegitimacy with increased age of women, we know nothing for certain. These figures are, perhaps, liable to misconstruction in another respect, for they include the illegitimate children of widows and unmarried women in middle life. What it would be very desirable to ascertain, is the age of girl-mothers when they give birth to the first illegitimate child. We should then know to what extent the greater evil exists; but this information is not yet anywhere obtainable.

2. From what class do they chiefly come?

Here, too, the facts are very meagre, consisting of a single inquiry for a single year, in Scotland. In 1883 , the occupations of the Io,oro mothers of illegitimate children were by the Registrar General tabulated as follows :- 
Domestic servants • • • • • 4706

Girls working in factories. . . 2442

" , on farms . . . . . 985

Seamstresses . $\quad . \quad$. $\quad . \quad$. 607

No occupation (chiefly daughters of working men)

Daughters of professional men . $\quad$ - 54

No information (chiefly widows) • $\quad$ - $\quad 385$

I0,010

3. To what extent is concealment successful?

This is a question, of course, impossible to answer by statistics, since naturally they cannot account for what is obviously concealed. It seems to be the general impression among physicians, best qualified to know, that, among classes able and willing to afford some expense rather than undergo disgrace, absolute concealment is of very ordinary occurrence. This, of course, does not apply to the lowest strata of population. "No one," says the author of "John Halifax, Gentleman," "can have taken any interest in the working classes without being aware how frightfully common among them is what they term 'a misfortune'; how few young women come to the marriage altar at all; or come just a week or two before maternity." But if this statement be true it 
must apply only to that lowest grade of society from whom the sense of shame has nearly departed. A little higher class of girls are pushed by their " misfortune" to the streets, there to swell, at least for a time, the ranks of prostitution. In the upper middle classes of society, misfortunes of this kind are doubtless very rare in comparison with others; but they are readily concealed: indeed, it is possible that the great majority of girl-mothers of the middle ranks not merely hide their fall, but ultimately marry persons who have no idea of their previous misstep. The character of Lady Dedlock is not unknown outside the pages of fiction. Even Lord Nelson carried to his grave the delusion that the mother of his "little Horatia" had borne no other children; and Sir William Hamilton died believing in the fidelity of his wife.

The evils resulting from illegitimacy as a phase of the social problem are for the most part evident enough. Perhaps it may be doubted whether in Christian lands the unhappiness it occasions can be equalled by any other deviation from rectitude. Far more serious than disgrace is that saddest crime of 
humanity, the infanticide to which it so often leads. It is only now and then that the veil is drawn, and we get full glimpses of the truth; but everywhere we are confronted with the facts that, even in Christian England, the chance of living for the illegitimate child is far less than for others. In 1875 the Registrar General pointed out that while the death rate of legitimate children during the first year of life was about 205 per thousand, that of illegitimate was more than twice as great, or 418 per thousand births. Some of the worst discre-

Table XVI.-To r,o00 Infants Born of each Class, how Many Died UNDER ONe Year? (1875).

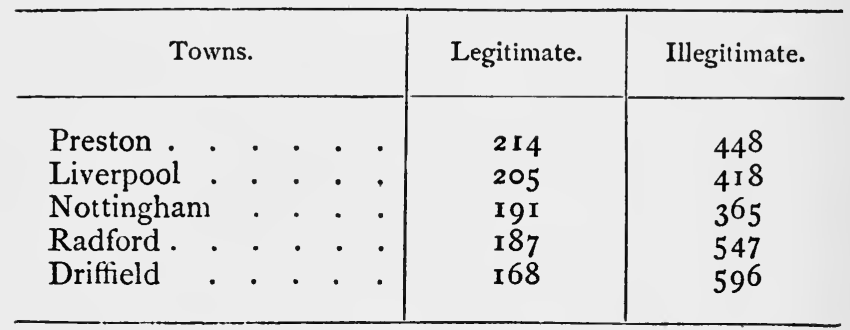

Note.- "During a long series of years it was found, in one part of Copenhagen (Denmark), that of illegitimate children, 45 per cent. of the boys, and 40 per cent. of girls, died before the age of one year, while the corresponding numbers for legitimate children were 20 and 18.-Dr. Sörensen, "Infant Mortality in Denmark." 
pancies between the chances for life of the two classes, are seen in the foregoing table.

Even in rural districts where the general mortality among infants was low, the same wide divergence was found between the two classes. In twelve districts with a specially low rate it was found that the proportion of children dying during the first year of infancy was 97 per thousand for legitimate, and 293 per thousand for the illegitimate. Even in Stratford-upon-Avon, the death rate for the one class was but 69 per thousand, against a rate of 239 per thousand for children of unmarried mothers! In Glasgow, observations extending over three years (1873-75) show that while the mortality of legitimate children fluctuated between I49 and I54 per thousand, under one year of age, the corresponding mortality of the illegitimate was between 277 and 293 per thousand, or nearly twice as much.

How much of this mortality is due to deliberation and design? How much to that criminal indifference and neglect which eludes detection and escapes punishment? We have it on high authority that in civilized England there are parents who will suffer their legitimate 
children to be starved to death for the sake of a few shillings insurance head-money. What chance then has the babe to live who, never welcome, was put out to a professional babyfarmer? Hardly a month goes by without some awful story of this kind coming to light; and yet how many of these babymurderers escape detection, and go on with their work! Coroners are justly suspicious of those frequent "accidents" to which these unfortunate and unwelcome infants seem so singularly liable. From the Judicial Reports of England and Wales I have extracted the number of coroner's inquests held during six years, simply upon illegitimate children under one year of age.

\begin{tabular}{|c|c|c|c|c|c|c|c|}
\hline & 1882. & I 883. & 1884 & 1885. & I 886. & 1887. & Total Six Years. \\
\hline $\begin{array}{l}\text { Boys . . } \\
\text { Girls . }\end{array}$ & $\begin{array}{l}482 \\
428\end{array}$ & $\begin{array}{l}498 \\
449\end{array}$ & $\begin{array}{l}560 \\
481\end{array}$ & $\begin{array}{l}5^{8} 3 \\
43^{8}\end{array}$ & $\begin{array}{l}541 \\
534\end{array}$ & $\begin{array}{l}555 \\
488\end{array}$ & $\begin{array}{l}3219 \\
2818\end{array}$ \\
\hline Both sexes. & 910 & 947 & IO4 I & $102 I$ & 1075 & 1043 & $6 \circ 37$ \\
\hline
\end{tabular}

These figures are sad enough when we know what they mean. What is the nature of these "accidents" ? The Registrar General tells us 
how these children die. They are suffocated, drowned, poisoned, strangled, scalded, burned alive. Yet these, perhaps, are more merciful exits than the induced disease, the slow starvation, the prolonged agony which many must undergo before finally released. Of these deaths by "misadventure," Dr. Acton says that the great majority, we are justified in assuming, "were the illegitimate offspring of first falls from virtue. The hopeless difficulty of rearing her offspring, the maddening misery and want, have, in most of these cases, caused the mother to raise her hand against the life she has given." This was written before complete statistics were available; but although we now see that the majority of coroner's inquests are not held upon illegitimate children, yet, in proportion to their number living, these are every year more than four times as liable to "accidents" as their legitimate kindred. Is there any explanation or reason for this? One, only. These are not all accidents. They are undetected and unpunished murders of unwelcome guests at the feast of life.

Nevertheless, regarding illegitimacy for a moment as a phase of social phenomena, but 
quite independently of its ethical relations, is it possible to discover in it any effect for good? I think we must admit, so considering it, that like other forms of generally deleterious action, such as War and Pain, even in this way, at the cost of individual happiness, Nature sometimes accomplishes a gain for humanity at large. It tends for one thing to level upward the human race. In the vast majority of cases of illegitimacy, the mother is the inferior of the two parents, not merely in social rank, but often in that fineness of mental and physical organization which results from better conditioned lines of ancestry. Thus, when two races are brought after the violence of conquest into relations with each other, and begin, the conquerors and the conquered, to blend into a single nationality, it is rather concubinage than marriage which breaks down the first barriers of prejudice. The tendency of legal unions is almost always upon a plane of equality; Cinderella we find in the fairy tales for children, but in real life it is Emma Lyons and Nelly Gwynn whom for the most part history shows us in her place. Of that fusion of Celt and Roman, Saxon, Dane, and Norman into the English people, 
how much was due at the outset to relations unsanctioned by Church or State? Why, even within the present generation we were told by Sir George Graham, the late Registrar General, that " if the mortality were not greater among illegitimate than among legitimate children, every fifteenth person in England must be of illegitimate extraction." 1 But this is merely the story of to-day. Begin to trace ancestry backward, and it is probable that in one branch or another, the bar-sinister would be found somewhere in the ancestral pedigree by more than half the general population of Great Britain, and by three-fourths of its aristocracy, before one reaches the period of the Reformation. Now so far as the English stock is improved in physical and mental calibre by infusion of better blood, just so far some benefit accrues to the race, even though it be at the cost of individual happiness and honour.

Everywhere the same phenomena are to be seen. In certain parts of America the aboriginal tribes are disappearing-not always by fire and sword, but through absorption into the

- Sixth Annual Report of Registrar General, p. $3^{8 .}$ 
conquering race; and in more than one American to-day, the blood of the Mayflower Puritans runs, in commingled currents, with that of the aboriginal tribes they dispossessed. One cannot travel through the States without noting that the thick lips, coal-black colour, low brow, and flat nose of the Guinea negro have almost disappeared in a hybrid race, with large admixture of English blood-changing not only the colour, but the intellectual capacity of the type; and I do not doubt that before half-adozen centuries have expired, the African will have as completely merged his race in the three hundred millions of the North American Continent, as Phenician and Greek, Saracen, Roman and Norman have blended in the Neapolitan who basks in the sunshine on San Lucia. The New Zealand traveller a thousand years hence, who from his reverie above the ruins of London Bridge turns his step homeward through the Gulf States of America, will find no negroes; but the labouring class of the population, the hewers of wood and the drawers of water, will no doubt show a warmer tint than obtains in what now is Canada and the Northern States. Yet I question whether this 
tawny population will more widely differ from the general mass, than the Sicilian or Calabrian differ from the nations of Lombardy, or the type of Grenada from that of Castile. Of course the greater part of this change is henceforth to be effected by lawful marriage, but the barriers between races are at first otherwise broken down; and this was no exception. The United States minister to Hayti is the son of a slaveholder and his slave. ${ }^{1}$

Nor can we deny the gain to humanity which here and there nature grants in individual cases,

1 At the International Congress of Hygiene and Demography held in London in August, 189r, Dr. Carlsen of Copenhagen presented a pamphlet showing certain statistical investigations concerning the idiots and feeble-minded portion of the Danish population.

"The illegitimate imbecile children amounted to 5 per cent. of the total number of imbeciles, while about ro per cent. of all births have been illegitimate in Denmark during a long period of time. As it is probable that the number of the imbeciles overlooked or forgotten in the counting is larger within the class of legitimate than within that of illegitimate children, we incline to the supposition (even if proper attention is paid to the fact of the greater rate of mortality for illegitimate children) that imbecility is scarcer among illegitimate than among legitimate chuldren; which accords very well with the fact, that the more malignant forms of imbecility occur less frequently among the illegitimate children." 
while still exacting her tribute of personal suffering. The world could ill spare all upon the accident of whose birth it puts a social stigma. Some of the greatest soldiers and adventurers of ancient and modern times, from William the Conqueror of England to Pizarro the Conqueror of Peru; from Marechal de Saxe to General Burgoyne-not to speak of a greater than them all, in our own time-might have borne the bar sinister upon their escutcheon. The most brilliant name in French journalism for forty years, Emile de Girardin, gained his position in literature by his genius, despite an openly acknowledged illegitimate origin. There died in France a few years ago an ecclesiastic than whom few more eloquent or far-sighted has the nation ever known; upon whom the Church conferred its highest honour, whom the French Academy raised to a seat among its Immortals ; yet the Bishop of Orleans was the son of a maid-servant at a Swiss inn, and knew no father. Who that visits Washington, the American capital, suspects that the only National Museum of the great Republic, the "Smithsonian Institution," founded "for the increase and diffusion of knowledge among men," 
was the generous gift, more than half a century ago, to a nation then insignificant in numbers, from the natural son of an English duke? When, a century ago, the American colonies had emerged from their conflict with the mother-country, it was chiefly the genius of one man who laid the foundation of that federal system, which, by a written constitution, moulded these discordant and petty States into the potentiality of a mighty nation; but Alexander Hamilton was of illegitimate birth, the son of a Scotch planter in the West Indies. One of the two greatest names in modern American history confessed his belief that whatever talent he possessed came to him through a parent whose birth was illegitimate. Philosophy, profiting by the studies of D'Alembert, one of the keenest mathematicians and most brilliant writers of the last century, does not identify the philosopher, honoured by the courts of Catherine II. and Frederic the Great, and by the Vatican itself, with a poor foundling picked up in the gutters of Paris. Literature forgets the stain of ignoble origin in Boccaccio, the father of Italian prose; in Erasmus of Rotterdam, the greatest name in the history of 
the Renaissance ; in George Sand, great grandchild of Maurice de Saxe, himself the natural son to Augustus, King of Saxony, or in Alexander Dumas of to-day, illegitimate son of a still more renowned father, who was grandson of a French marquis and a slave-woman of San Domingo. Who that stands in the refectory of the Dominican Convent at Milan before the fading outlines of that matchless masterpieceThe Last Supper-remembers the story of Leonardo di Vinci's birth? Who that reads the story of Pharez connects him with the history of David?

What of prevention? Here is a social evil growing out of laxity of life, but it is an evil of which the heaviest penalty falls upon those least to blame. Something indeed may be hoped from the strengthening of religious influences, and the inculcation of a greater sense of responsibility, or by modification of laws and customs which directly or injuriously hinder early marriages. Unfortunately, the truth is, that everything which makes for early and improvident marriages tends to repress illegitimacy; while all prudential restraints, whether imposed by law or custom, tend to its 
increase. One good thing is certain, that in England there has been a steady fall, in the rate of illegitimacy since the year 1845 . In that year the rate was 70 per thousand births. In 1889 the proportion was 46 .

Is it not possible to ameliorate in some measure the awful evils which spring from it? Without in any degree lessening for young men the obligation to chaste and sober lives, might it not be possible to suggest also the truth that paternity, even outside the law, creates duties which no honourable man will ever seek to evade? For no child meets with death from the hands of her whose breast should have been its safest refuge, or, abandoned to its fate, is slowly tortured out of existence in the filthy attic of a "baby-farm," except from the neglected secondary duty of some man. The performance of such parental obligations may not indeed atone for the primary fault; but that fault is infinitely increased by its neglect. It needs to be affirmed that honour creates responsibilities which the law may not enforce; that parentage implies duty; that the natural right of illegitimate infancy to paternal support depends in no way upon legal claims or good- 
natured generosity, but upon the foundation principles of justice and right.

And finally it seems to me very questionable whether that essentially feminine sentiment which affixes upon illegitimate motherhood of a young girl the stigma of irreparable infamy, does not, in the majority of cases, accomplish more evil than good. It may be well to teach innocence the exceeding sinfulness of sin; yet even here there is a tendency to evil consequences just so far as we overstep exact truth. To assert that by maternity out of marriage, the character and nature of a young girl is infected with pollution; that if a housemaid she is henceforth unfit to care for children, and for the sake of example and in the name of Virtue, should be turned forthwith, and without warning, upon the streets, as the pitiless law of England to-day permits, - this is not merely false, but the underlying sentiment that inspires such action is both inexpedient and unjust. Is it maternity that destroys the purity of womanhood, or the lapse which precedes maternity? For one, I refuse to believe that we ever can make virtue seem more lovely by the merciless punishment of that consequence, which alone 
more than half condones the sin. I very seriously question whether every seventh mother in some counties of Scotland is worthy of that stigma of dishonour which belongs to her only who sells herself for hire.

Nor is it expedient, because whenever the extreme penalty of ostracism is mercilessly inflicted, we create a yet greater evil than the one it is sought to condemn. Between that first child of the young country girl, and those depths of sin, to which the painted hetaire of the pavement has fallen, is an almost immeasurable abyss. Yet it needs but a step to reach that lower level; a step over a precipice. That Christian woman who, deaf to all entreaty, turns her maid into the streets because about to become a mother, may fancy she is only upholding the dignity of virtue; but she is also opening to her sister woman the gates of hell. She has created that despair which pushes its victims into a chasm, wherein thousands of her sisters annually fall. Prostitution is the final resource of illegitimate maternity; and more than one Fantine sells her soul on the streets of London to keep her child alive. 
But even this is not the lowest depth. She who pushes her sister towards despair helps to create in her soul the temptation to escape all ignominy by infanticide. We do not need the genius of Scott, of Goethe, of George Eliot to tell us that in our Christian civilization a mother can do, what the old Hebrew thought almost impossible, "forget her sucking child." Even the criminal records give us but a hint of the awful evil that in reality exists. There is no danger more terrible than this; for in the soul of a woman who has lost the instinct of maternal love there is indeed a ruin beyond repair.

I hope it may not be wholly an idle dream that, at some period in the development of Christian charity and civilization, a point may be reached where she who is about to become a mother of an unwelcome child, because she trusted too faithfully and loved too well, will find somewhere a sure refuge; meeting there neither a blind sympathy that hastens too quickly to condone, nor yet an unpitying virtue that scorns forgiveness and invites to despair. In her sad extremity, perchance then she may be encouraged by woman's heart and helped 
by womanly hands not to evade the responsibilities of motherhood, but to meet them so bravely, to fulfil them so conscientiously, that in time even the stain of her dishonour shall fade away, and her transgressions, through duty well performed, find forgiveness and expiation.

\section{CONCLUSIONS.}

I. Illegitimacy is a phase of social phenomena produced by the conjoint action of several causes. Its variance in different localities depends upon the force and number of the factors there present.

II. These causes differ in energy; they sometimes neutralize each other; but on the whole, with certain exceptions, hereafter noted, the rate of illegitimacy fairly expresses their effect upon the private sentiment of the community concerned.

III. In all sections of the United Kingdom it is chiefly prevalent where thrift and prosperity are most general, and is least in that country where poverty is the ordinary condition of the mass of the people.

IV. In Great Britain it seems to prevail least 
among the population of cities, and chiefly in rural communities.

$\mathrm{V}$. Among the nations of Europe it is most common where elementary education is most generally diffused; and least among some of the most illiterate communities, as in Brittany and Ireland.

VI. It is probably increased by any restraint on early marriage, whether imposed by law, or custom, or arising from severe industrial depression.

VII. The influence of religion is one of the most powerful agencies against unchastity; but the effect upon illegitimacy of a religious creed apparently has no relation to its dogmatic truth.

VIII. Differences in the annual prevalence of illegitimacy in different localities or sections of the same country are so marked, and so persistent, that only by the hypothesis of hereditary influence can we at present account for them.

IX. As a means for testing the comparative sensitiveness of different people to moral laws, the rate of illegitimacy can only serve when the totality of general environment is similar, as 
between cities or communities under the same general government. We cannot always infer the existence of a higher tone of morals from a low rate of illegitimate births (I) in countries where ante-natal destruction of life largely prevails; (2) in countries where young women are specially guarded before marriage, yet wherein marital fidelity may be less observed; (3) in countries wherein polyandry is alleged to exist as an acknowledged custom; or (4) in great cities where other vices counteract tendency to this, and where opportunities for concealment are far greater than in country districts.

$\mathrm{X}$. While the rate of illegitimacy is widely different in each of the three divisions of the United Kingdom, it is evident that in each it has been slowly declining for many years. It appears also to be decreasing in frequency in the greater part of Europe, at least when measured by the rate prevalent twenty years ago. 


\section{THE INFLUENCE OF SEASONS UPON CONDUCT.}

In the "Journal of Marie Bashkirtseff," that book without a parallel, that "exhibition of an imposing tapestry in reverse," as Mr. Gladstone has so aptly called it, there occurs a passage wherein the young girl-artist attempts to describe her ideal of a painting, upon which she was unconsciously putting the last enthusiastic labour of her fading life. It was an endeavour, as her biographer tells us, to express the inmost spirit of Springtime by line and colour; all that mysterious fermentation which accompanies the reviving year. "I go to Sevres every day; this picture possesses me," she writes in her journal. "The apple-tree is in blossom; the leaves beginning to come out, there are violets in the grass. The air is balmy, and the girl who dreams, leaning against the tree, is 'languishing and intoxicated.' . . . 
It would be fine if I succeeded in rendering the effect of sap in the spring! . . . I want a real big goose of a girl, who dreams, overcome by the heat, and who will yield to the first peasant who chances to go by."

If there is in this passage a realism of expression a little foreign to our general usage, it betrays notwithstanding that curious gift of insight within the very heart of Nature, which Marie Bashkirtseff possessed. For she touched here a mystery of profound significance. Art and poetry have long affirmed the emotional tendencies which accompany the budding year: we know by heart Tennyson's oft-quoted lines. Now beyond fanciful but vague sentiment, is it possible to penetrate to the truth, and to discover in so distant and abstract a circumstance as the season of the year, any periodical and distinct incitement toward human actions? One is inclined, at first thought, to relegate such an inquiry to other ages, when planets decided destiny, and the stars in their courses fought against Sisera. But this question to-day commands somewhat greater respect than is due the dreams of astrology. It is a scientific problem, because facts are observed, which are 
explicable on no other hypothesis than a disturbance of equilibrium, so to speak, which so regularly recurs, year after year, as to denote the activity of some law of causation.

It is not a new theory, though I propose to carry it somewhat further than it has been pushed hitherto. Over half a century ago, Quetelet in his great work "On Man," suggested the hypothesis, although he deplored the want of statistical evidence which alone hindered verification of strong probabilities. To-day we are far better situated, so far as concerns opportunity for the observation of phenomena of human action in abnormal directions. The hypothesis toward which all the facts point is simply this; that upon the nervous organization of human bodies (perhaps specially upon dwellers in the temperate zones) there is exerted during the procession of the seasons, from winter's close till midsummer, some undefined, specific influence, which in some manner tends to increase the excitability of emotion and passion, and thus also to increase all actions arising therefrom. How this is accomplished is another problem, of which more hereafter. Naturally too, we can see but 
a very limited portion of the field of human conduct; for only those actions which are so serious as to call for legal or medical investigation can be subject to scientific observation. If, however, there be any truth in the hypothesis we should expect these when studied en masse to be uniformly more frequent at certain periods of the year than at others. Are they? What are the facts?

There are six phases of human conduct in regard to which I believe the action of this cosmic force may be recognised. These are :-

I. Suicide, accomplished or attempted.

II. Crimes against Persons.

III. Murder and Homicidal Assaults.

IV. Crimes against Chastity.

V. Attacks of Insanity.

VI. Births, especially the illegitimate births.

Besides these there are one or two others, upon which some light glimmers, but as yet not clearly.

I. Suicide.-Whether or not we assume selfdestruction as the evidence of unsound mind, it is certain that nearly always it results from a temporarily distorted estimate of the value of 
further existence. A man may apparently be sane enough on every other topic; it is only about himself or some conditions of personal environment that his ideas are unbalanced.

For a long time, suicide was supposed to find its culmination of frequency, particularly in England, at that season of gloom when poverty and distress are most keenly felt. But this notion has been ruthlessly swept away by the evidence of statistics. Nothing apparently is more clearly proven than that the tendency to suicide in every country in Europe regularly increases from the end of winter until July, and then slowly declines. Morselli has shown that the point of greatest aptitude toward suicide during the periods observed was reached, for Ireland, Saxony, Austria, Sweden, and Holland in May; for France, Italy, Russia, Norway, Belgium, and Denmark, in June; and for Switzerland and one or two divisions of the German Empire as late even as July. For the majority of dwellers in Europe the greatest extreme of tendency towards suicide will, I think, some day be discovered to be a period of about five weeks in May and June. On the other hand, without exception, that period of 
the year when the suicidal impulse is least felt occurs during winter when cold, hunger, and destitution are generally most severely felt.

We may see the facts clearly, if we divide the year into two parts and calculate the proportion of suicides which in different countries occur in each half year; and this I have done in the final table.

But the operation of this law is not confined to Europe alone ; and in the statistics of the extreme Orient, I have recently found a remarkable coincidence of the same phenomenon.

Table I.-Proportion of Suicides in each Season of the Year to the total Number.-J Japanese Empire.

\begin{tabular}{|c|c|c|c|c|c|}
\hline Seasons. & 1882. & I883. & I 884 . & 1885. & $\begin{array}{l}\text { Average } \\
4 \text { years. }\end{array}$ \\
\hline 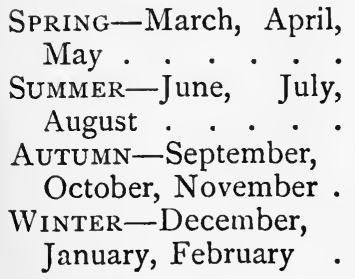 & $\begin{array}{l}30 \\
23 \\
19\end{array}$ & $\begin{array}{l}28 \\
29 \\
22 \\
21\end{array}$ & $\begin{array}{l}27 \\
29 \\
22 \\
22\end{array}$ & $\begin{array}{l}27 \\
32 \\
23 \\
18\end{array}$ & $\begin{array}{l}27^{\circ} 4 \\
30 \\
22 \cdot 6 \\
20\end{array}$ \\
\hline Total Year & 100 & 100 & 100 & 100 & 100 \\
\hline
\end{tabular}


If we take the suicides of the Japanese Empire for several successive years, it will be found that they recur in each season of the year in almost the same proportion as in Western Europe.

Thus, year after year, in Eastern Asia, between 57 and 59 per cent. of all suicides occur in the two seasons between the Ist of March and the last of August.

How is it with ourselves? Unfortunately the data furnished by the Registrar General, except for London, tell us nothing of the season of suicide in England and Wales. It so happens, however, that some knowledge is obtainable from another quarter. When the would-be suicide fails in the attempt at self-destruction the act becomes a crime to be noted by the Police, and accounted for in the Judicial Reports, where criminal returns are made for each quarter of the year. These cases of attempted suicide, numbering about a thousand a year (10,733 for ten years, I878-87), probably represent only a small part of those which actually occur; since of course in a private family of means, the act would be treated by physicians and friends as merely an incident to the delirium 
of a disordered mind. It is different, however, when a girl flings herself over London Bridge, or a man shoots himself in Whitechapel. Now if we divide the last ten years for which the Judicial Reports afford the facts, into three periods, we shall see how exactly the intensity of suicide-tendency in this country agrees with the accession of spring and summer, and how uniformly it decreases during the colder seasons.

Table II.-Of Attempts at Suicide in England and Wales DURing Ten Years, what per cent. OCCURRED dURING EACH QUARTER OF THE YEAR?

\begin{tabular}{|c|c|c|c|c|}
\hline Quarters of the Year. & I $878-1880$. & $188 \mathrm{I}-1883_{3}$ & I884-1887. & $\begin{array}{l}\text { Average for } \\
\text { Io years. }\end{array}$ \\
\hline $\begin{array}{l}\text { April, May, June } \\
\text { July, Aug., Sep. } \\
\text { Oct., Nov., Dec. } \\
\text { Jan., Feb., March. }\end{array}$ & $\begin{array}{l}28 \\
32 \\
21 \\
\text { 19 }\end{array}$ & $\begin{array}{r}29 \\
30 \\
22 \\
\text { 19 }\end{array}$ & $\begin{array}{l}29 \\
32 \\
19 \\
20\end{array}$ & $\begin{array}{l}28 \cdot 8 \\
31 \cdot 6 \\
20^{\circ} 3 \\
19 \cdot 3\end{array}$ \\
\hline & 100 & 100 & 100 & 1000 \\
\hline
\end{tabular}

In England and Wales, therefore, fully sixty per cent. of all attempts at suicide occur during the warmer seasons, and forty per cent. during autumn and winter. See how closely these proportions agree with those of Japan! 
For the metropolis we are able to get nearer to the truth regarding the act of suicide itself. In a paper read before the Royal Statistical Society in February I886, Dr. W. Ogle has calculated the average monthly distribution of all suicides in London during a period of twenty years, 1865-1884. In each thousand cases of self-destruction annually occurring the proportion for each season is found to be as follows :

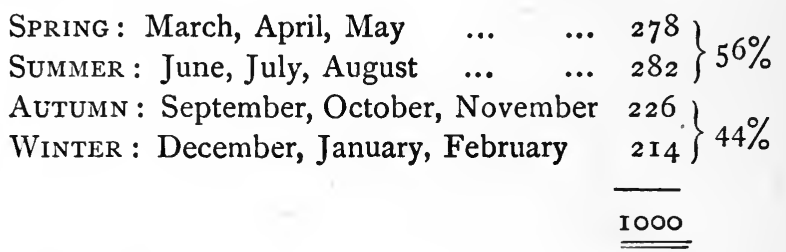

Notwithstanding the fact that distress among the London poor is far greater in winter than at any other season,-suicide then is least prevalent, and most frequent in May and June.

Does this suicidal tendency manifest itself uniformly year after year? It does. If we construct a diagram from the exact numbers of attempts at suicide in England, during each quarter, extending it over a continuous period of several years, we can clearly see how this wave of impulse sweeps over us. 
SEASON'S AND CONDUC'T.

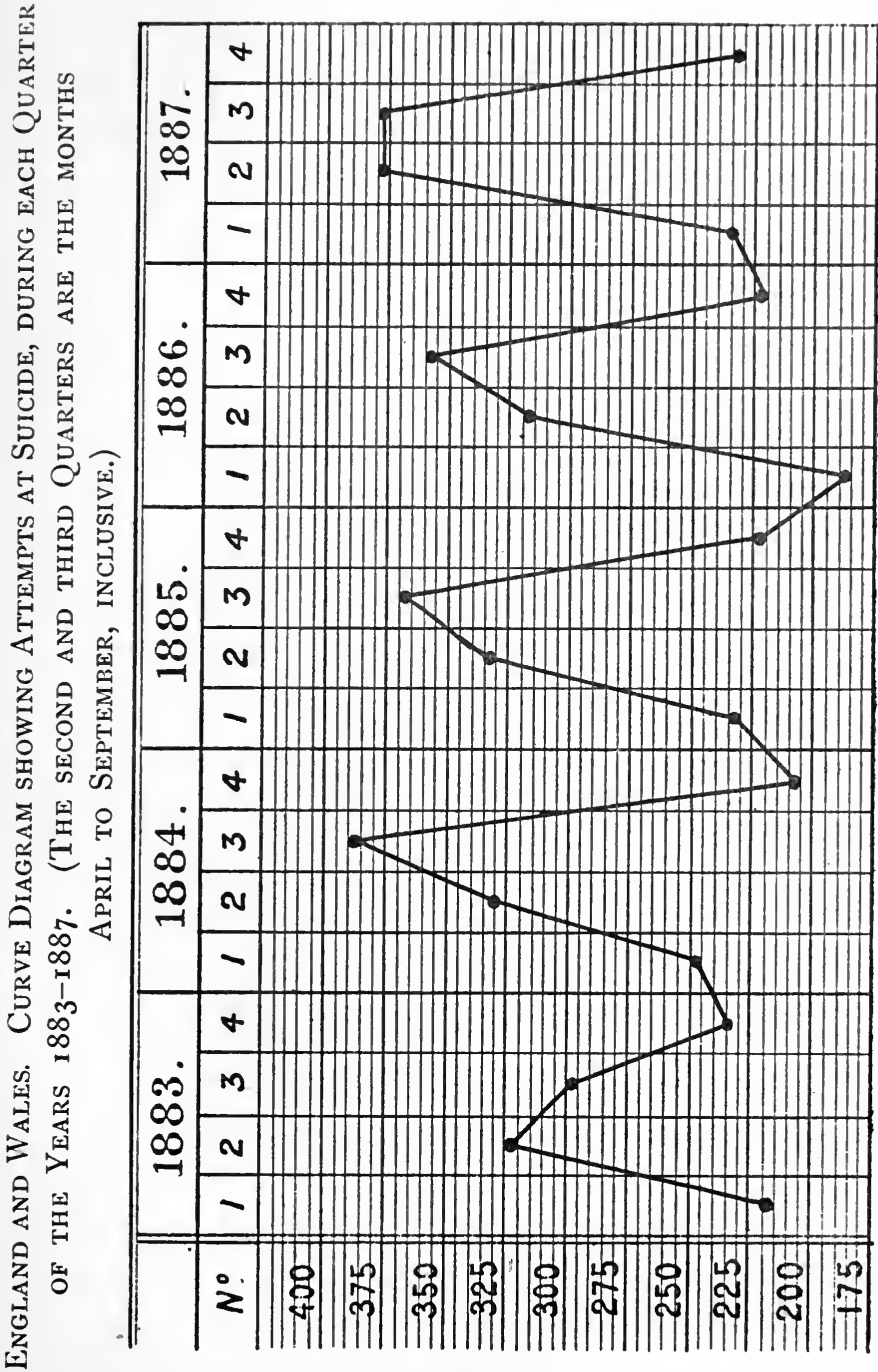


- Looking at such a diagram, the physician can hardly fail to note its resemblance to the tracing of a pulse, or the rise and fall of temperature during progress of a fever. It may be that such resemblance is even more than a fancy, and that suicide thus marks in truth the variations of the fever of life. At all events there can be no doubt whatever of the periodicity of change, regularly coincident with the advent of the opening year. Everywhere in northern climes the number of voluntary deaths steadily increases from the beginning of the year until May, June, or July, and then as regularly and uniformly declines.

II. Insanity. - Why is it that at certain and fixed periods in the cycle of the year, a sort of tidal wave of mental aberration regularly sweeps over civilized mankind? Wherever the facts are investigated it is found that with the advent of spring, and extending into the summer, there is invariably an increase in lunacy. For a long time it has been noted by those in medical charge of asylums for the insane, that as spring advances an increase in excitement, a peculiar mental restlessness, seems to affect the patients ; but facts of this nature have not thus far as- 
sumed any statistical expression. In the admission of patients attacked with insanity to asylums and retreats, we are face to face with evidence upon which we can depend.

This phenomenal increase of mental excitement or depression has also been noted for many years. Quetelet refers to the admissions into the great Insane Asylum at Charenton near Paris, of which 54 per cent. were received between the ist of March and the ist of September. Drs. Bucknill and Tuke quote similar figures (but without date) which by calculation produce the same proportion, and show that 54 per cent. of admissions to asylums occur during the warmer months. But I have more recent evidence. In the last report of Dr. Ritti, the physician in charge of the female wards at Charenton, he gives the number of admissions for the years from 1879 to 1888 . Of these 53 per cent. are during the period between March and August, and 47 per cent. between September and the following February. "During the last ten years," writes Dr. Ritti, " it is in spring-time that the admissions have become the most numerous; they have slightly diminished during summer, and reached their 
minimum during the last months of the year."

But by far the most complete and interesting of recent statistics on this subject that I have been able to find, are contained in the Lunacy Reports of Scotland. Here for two different periods, of not less than eighteen years altogether, the admission to asylums may be seen for each month; and as the total number of the insane thus accounted for is over 38,000 , the averages thus obtained undoubtedly represent, with exceptional accuracy, the working of the law. And every year the story is substantially the same. Commencing about the month of March, the number of admissions to retreats and asylums begins to rise above the average of the year, and gradually attaining its maximum during the early part of the summer, falls below the average in September, and remains below during the autumn and winter, only to rise again with the advent of the season of fertilization.

In other words, certain forms of insanity are coincident with the impulse to suicide, subject alike to an increasing prevalence with the coming of spring. 
TABLE III.-OF EACH I,000 Admissions to Insane AsYlums in Scotland DURING the PERIODS NAMED, HOW MANY OCCURRED DURING DIFFERENT SeAsons?

\begin{tabular}{|c|c|c|c|c|}
\hline \multirow{2}{*}{ Seasons. } & \multicolumn{2}{|c|}{ Men. } & \multicolumn{2}{|c|}{ Women. } \\
\hline & $\begin{array}{l}\text { I } 865-74 \\
10 \text { years. }\end{array}$ & $\begin{array}{l}\text { r88o- } 87 \\
8 \text { years. }\end{array}$ & $\begin{array}{l}\text { I } 865-74 \\
\text { Io years. }\end{array}$ & $\begin{array}{l}1880-87 \\
8 \text { years. }\end{array}$ \\
\hline $\begin{array}{l}\text { Spring and } \\
\text { Summer. }\end{array}$ & 527 & 529 & 533 & $53^{8}$ \\
\hline $\begin{array}{l}\text { Autumn and } \\
\text { Winter. }\end{array}$ & 473 & $47 \mathrm{I}$ & 467 & 462 \\
\hline Total being & $1, \infty 00$ & 1,000 & 1,000 & 1,000 \\
\hline
\end{tabular}

Both sexes are apparently susceptible to this mysterious influence, although in slightly different proportions. But whether for men or for women, for one period or another, or for single years, about 53 per cent. of all persons attacked with insanity in Scotland are admitted to asylums and retreats during the six months following the ist of March. There can be no dispute about facts so susceptible of proof, so recurrent every vear. The precise figures for 
each month of the year will be found of interest to the student, and are given elsewhere. ${ }^{1}$

The remarkable correspondence between the varying proclivity to attacks of insanity and the tendency towards self-destruction has not failed to attract notice.

If upon the same scale we trace a diagram which for successive months shall indicate the proportionate percentage of attacks of insanity, almost exactly the same curve will be taken by suicide, except that the influence of spring is far more intense toward self-destruction. In regularity of course upward till midsummer, and downward during the remainder of the year, the line of perturbation is almost exactly the same. Both are nearly at their lowest degree of frequency when the year begins; both rise with advancing spring; both culminate at the same period, and decline with the dying year. This coincidence has led some writers to insist on the greater frequency of suicide in summer by reason of its relation to mental disease. The hypothesis is a plausible one; some connection undoubtedly exists between

${ }^{1}$ See Table in Appendix. 
them, but I question whether it be that of cause and effect. It so happens, as Morselli has pointed out, that whenever a distinction is made between cases of self-destruction occurring during an insane attack, and those due to other causes, precisely the same phenomenon is seen in both instances; the highest rate of frequency is found in spring and summer.

Table IV.-Of Suicides due to Madness or to other CAUSES, WHAT PROPORTION OCCURRED DURING EACH HALF-YEAR?

\begin{tabular}{|c|c|c|c|c|c|c|}
\hline \multirow{2}{*}{ - } & \multicolumn{3}{|c|}{ Suicides due to Insanity. } & \multicolumn{3}{|c|}{ Suicides due to other causes. } \\
\hline & Italy. & France. & Belgium. & Italy. & France. & Belgium. \\
\hline Spring and Summer & $64 \div 4$ & $58 \cdot 9$ & $56 \cdot 3$ & $59^{\circ} 0$ & 56.7 & $57 \cdot 1$ \\
\hline Autumn and Winter. & $35^{\circ} 6$ & $4 I \cdot I$ & 437 & $4 I^{\circ} \circ$ & $43 \cdot 3$ & $42 \cdot 9$ \\
\hline The year being. . & $100 \%$ & $100 \cdot 0$ & $100 \cdot 0$ & $100 \cdot 0$ & $100 \cdot 0$ & $100 \cdot 0$ \\
\hline
\end{tabular}

The inference is clear, for unless we ascribe all suicide to madness, it is impossible to explain its variation by season on the theory of insanity. Even then, we but push the problem a little backward; what produces the suicidal insanity? It seems to me that we must look for some influence which is common to both 
phenomena, as an exciting or predisposing cause of each.

III. Crimes of Violence.-All actions are criminal which are in violation of the law. A crime is not necessarily morally wrong; it may be on the contrary a very noble and meritorious protest against injustice and tyranny, and yet by the laws of the country be punishable even with death.

Putting aside all minor subdivisions, crimes in every country, whether civilized or barbarous, may be divided into two great classes : infringments upon rights of Property, or injuries to the Person. The exciting causes which induce these two kinds of offence, are as a rule different. In the predatory instinct of the habitual thief, or the sudden impulse of temptation in destitution, we see examples of those causes which provoke crimes against property. These impulses, coincident often with opportunity and temptation, are peculiar to no season or clime, except that they are more frequent and numerous when food is dear, and work difficult to obtain. In India, crimes against property are in almost exact coincidence with the failure of crops, or the abundance and cheapness of food. 
Crimes against persons, on the other hand, manifestly arise from very different causes. In the majority of cases they are the outcome of powerful passions, which, suddenly excited, break down all the barriers of prudential selfcontrol. 'Sudden anger, and resentment springing even from the most trifling disputes, desire for revenge of deeper injuries, real or imaginary, jealousy and rage, and other passions, common to brute and man,-all these may occasion assaults upon the person of the individual.

It is therefore in this class or species of crime that we may expect to detect the influence of seasons, if such influence exists.

Now the Judicial Reports of England and Wales fortunately afford us means of testing the problem, since we can tabulate year after year, all crimes against persons, so far as these offences were reported to the police authorities. If there be no effect upon criminal acts exerted by the variance of temperature and the change of season, we should find no correspondence to exist between them. Murderous assaults, for example, or crimes growing out of sex-passions, would be distributed over the entire year, with- 
out preponderance at any season; or manifesting a preponderance, sometimes in winter, and sometimes in spring. In the following table I have grouped together in one class all assaults affecting human life, excepting only the murder

Table V.-OF the total NUMber of Murders or Murderous Assaults in England and Wales during a period of TEN Years, how MaNy OCCURRED DURING EACH OF THE FOUR QUARTERS OF THE YEAR?

\begin{tabular}{l|c|c|c|c}
\hline & \multicolumn{2}{|c|}{ Total No. of Crimes. } & \multicolumn{2}{c}{ Per cent. each quarter year. } \\
\cline { 2 - 4 } & 1878-1882. & x883-1887. & 1878-1882. & 1883-1887. \\
\hline I. Jan., Feb., March, . & 412 & 451 & 21 & 23 \\
2. April, May, June . & 491 & 506 & 25 & 25 \\
3. July, Aug., Sept. . & 566 & 567 & 29 & 28 \\
4. Oct., Nov., Dec. . & 488 & 469 & 25 & 24 \\
\hline Total . . . . & 1957 & 1993 & 100 & 100 \\
\hline
\end{tabular}

of infants under one year. I do not suppose that the inclusion of these would materially change the result; but infanticide differs from other acts of homicide in this respect, that it does not spring from passionate rage or anger against the victim, but is more frequently the outcome 
of selfishness, of desire to avoid responsibility, or to escape shame. The preceding table includes all other cases of murder or manslaughter, and all reported attempts at homicide of every description in England and Wales for a period of ten years. Of the total number of such crimes in each of two periods, what per cent. occurred in each of the four quarters of the year?

It appears, therefore, that in England and Wales 53 or 54 per cent. of homicidal or murderous attacks occur during the period from April Ist to Sept. 3oth, as against 46 or 47 per cent. during the colder months of the year. Or to put the figures in another and perhaps more intelligible form, we may say that during the ten years mentioned, $1878-1887$, the number of murderous attacks occurred as follows :

In Spring and Summer (April to Sept.) . 2128 In Autumn and Winter (Oct. to March) . 1820

It is an excess of about three hundred homicides or attempted homicides during the warmer half of the year over and above what occur in autumn and winter. Probably, too, a certain number of murders owe their incitement to avarice and greed, rather than personal ani- 
mosity ; arid these would be distributed throughout the year. If only those arising from passion could be included, the proportionate difference would undoubtedly be very much greater.

There is one species of crime more obviously brutal than all others in its origin and character; I refer to assaults by force upon the chastity of women and girls. The philosophic student of the twenty-first century, contemplating the perplexing phases of social life in an age which we sometimes fancy to be almost the noon of civilization, will wonder how it happened that in Christian England, until the year 1885 , a girl of fourteen years was deemed incapable of entering into any legal contract whatever, yet presumed to be perfectly capable of tacitly assenting to her own ruin. Now I have taken from the Judicial Reports the total number of crimes springing from sex-passion, so far as these were known to the police, during a period of ten years. It is exceedingly probable that many more crimes of this character were, from various motives, concealed from the authorities; but these as given are sadly significant. I have divided them into two periods of five years each. 
Table VI.-Number of Crimes pertaining to SeXPassion (Rape, and Assaults against Chastity), in England and Wales, during Ten Years, I878I 887, AND THE PROPORTION COMMITTED EACH QUARTER OF THE YEAR.

\begin{tabular}{|c|c|c|c|c|c|c|}
\hline & \multicolumn{3}{|c|}{$\begin{array}{l}\text { Total number of Crimes } \\
\text { reported to Police. }\end{array}$} & \multicolumn{3}{|c|}{$\begin{array}{l}\text { What per cent. } \\
\text { occurred during each } \\
\text { Quarter? }\end{array}$} \\
\hline & $\begin{array}{l}1878-82 \\
5 \text { years. }\end{array}$ & $\left|\begin{array}{l}x 883-87 \\
5 \text { years. }\end{array}\right|$ & $\begin{array}{c}\text { Io } \\
\text { years. }\end{array}$ & $\mid x 788-82$ & r883-87 & $\begin{array}{l}\text { ro } \\
\text { years. }\end{array}$ \\
\hline \multirow[t]{2}{*}{$\begin{array}{l}\text { First Quarter: } \\
\text { Jan., Feb., March } \\
\text { Second Quarter: } \\
\text { April, May, June } \\
\text { Third Quarter : } \\
\text { July, Aug., Sept. } \\
\text { Fourth Quarter: } \\
\text { Oct., Nov., Dec. }\end{array}$} & $\begin{array}{r}611 \\
866 \\
987 \\
599\end{array}$ & $\begin{array}{c}866 \\
1359 \\
1556 \\
1053\end{array}$ & $\begin{array}{r}1477 \\
2225 \\
2543 \\
1652\end{array}$ & $\begin{array}{l}20 \\
28 \\
32 \\
20\end{array}$ & $\begin{array}{l}18 \\
28 \\
32 \\
22\end{array}$ & $\begin{array}{l}19 \\
28 \\
32 \\
21\end{array}$ \\
\hline & 3063 & 4834 & 7897 & 100 & 100 & 100 \\
\hline
\end{tabular}

This table is of special interest. In no species of crime is the apparent effect of cosmic influence so evident as in offences of this kind. This is extremely significant.

It will be observed, of course, that the quarters of the year do not correspond with the seasons; but the divergence is not great. March is included with winter, and September goes with summer; but in all probability the influence of the first month of spring is stronger than the first month of autumn. 
I have divided them into periods of five years, so that the reader may not only note how closely they correspond in proportional prevalence, but also that remarkable fact-the great increase of crimes of this character during recent years. In 1879 the total number of cases reported was 542 . In 1887 the number had risen to I,210, more than double. Yet there is no substantial change as regards the time of the year: whether for the first period or the last, it is just sixty per cent. of offences that apparently must needs come between the first of April and the last of Sept. A considerable part of this increased criminality was due to a change of the law. If it were true that we cannot make men virtuous by Act of Parliament, at least we can make them criminals; the law of the land to-day makes that a felony which for centuries of English history could not be legally punished. It is very curious to note the rise of crimes as the law begins to take effect.

The fluctuation of crimes of this character from season to season will be best seen by a diagram based upon the actual numbers for each quarter year. For example, during the 
first quarter of the year I $S 80$, the total number of crimes of this kind was 140 ; the next quarter, from April to July, it rose to I80; from August to October, the third quarter, it remained at 182 , rapidly falling during the colder season, and rising with the following spring. ${ }^{1}$

In France, too, the same correspondence between offences against chastity and the season of the year has been long noticed. In $185 \mathrm{I}$, Dr. Villerme, in the Annals d'Hygiène, pointed out that a distribution of these crimes according to months discovered their especial frequency in May, June, and July. Later observations by Profs. Lacassagne and Tardieu, by Drs. Garraud and Bernard, confirm absolutely the earlier reports, and show that for France, as the last-named author states, "c'est en mai, juin, juillet et août que s'observe la plus grande frequence des attentats aux mœurs." 2 The curve from month to month through the year follows almost absolutely that taken by suicide and insanity, except that its

1 From Tables in Appendix the reader can test the accuracy of this and other diagrams, by constructing them for himself. See diagram on the following page.

Arch. Anthropolog. Crim. 1886-7. 


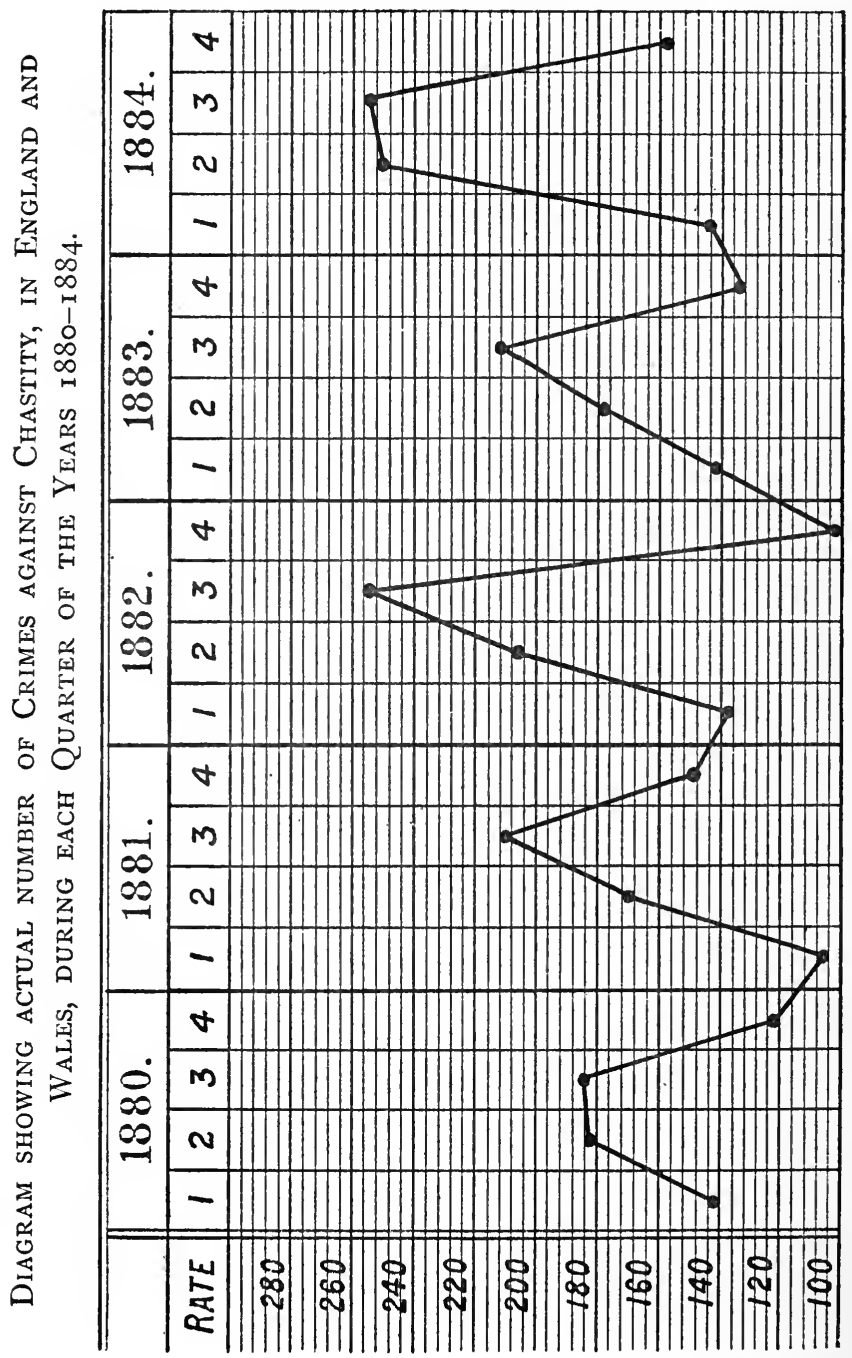


rise and fall are more abrupt. Tardieu gives the figures for ten years 1860-69, showing no less than $6_{3}$ per cent. of the whole number of such offences occurred during the six months April-October; and almost the same result is shown by Bernard in his article to which I have referred.

IV. All Crimes against the Person.-The totality of "Crimes against Persons," exhibits the same phenomena, though in a less marked degree. It so happens that among crimes thus tabulated, there are some offences which perhaps are quite as frequently against the welfare of the commonwealth as against the individual. "Bigamy," for instance, or " child stealing"; "the abandonment of infants," or "concealment of their birth," are all tabulated in this country with "murder and manslaughter," as crimes against the person.

'Taking, nevertheless, the total number of all crimes against persons, for ten years ( $1878-87$ ), including not only those of the more serious kind just tabulated, but all others so far as known to the police, we find them to have been committed in months undermentioned in following proportions. As affording an interesting 
comparison, I have brought together the same facts for Ireland, during the period of the years $1878-87$, and for France during forty years, I $830-1869$.

Table VII.-OF total Crimes against the Person, WHAT PER CENT. WERE COMMITTED DURING THE SEASONS SPECIFIED?

\begin{tabular}{l|c|c|c|c|c}
\hline & Spring. & Summer. & Autumn. & Winter. & Year. \\
\cline { 2 - 5 } $\begin{array}{l}\text { England 10 years, } \\
\text { I878-87 }\end{array}$ & 26 & 29 & 24 & 21 & 100 \\
$\begin{array}{l}\text { Ireland 10 years, } \\
\text { I878-87 }\end{array}$ & 25 & 28 & 24 & 23 & 100 \\
$\begin{array}{l}\text { France 40 years, } \\
\text { I830-69 }\end{array}$ & 28 & 27 & 22 & 23 & 100 \\
\hline
\end{tabular}

Here, again, we find that all crimes, even those arising from personal antipathy or hatred, seem specially prevalent in the warmer half of the year. In England, 55 per cent. of all such acts of violence during the ten years I878-1887 happened in spring and summer, and in France during a period of forty years the average was the same. ${ }^{1}$ Ireland, indeed, shows a more

1 The figures for France are taken from the "CompteGen. de la Justice Criminelle," p. cxvi. [1880]. See also Appendix. 
even distribution of such crimes; but the same tendency is seen even there.

V. Birth-rates. - The influence of season upon the birth-rate was suggested by Quetelet in 1824 , who then pointed out that the number of children born in Belgium every year was always greatest about the months of January and February, a fact which supposes the maximum of conceptions in April and May. Now, among human beings is there yet remaining any trace of that instinct which leads birds to mate when winter goes, and which in earlier periods of man's development was perhaps as strong with him as with other animals? If it exists, should we find any difference, in and out of the marriage relation? The subject is so little known that I shall offer no apology for presenting whatever facts are obtainable.

On some accounts it is more satisfactory here to obtain proportions of each month or season to every 1,200 births occurring during the entire year; since we then have a rate due each month of exactly roo births, and can see at a glance whether in any given number of months we have more or less than the numbers due. 
Table VIII.-Of each I,200 Legitimate Births Annually, how MaNy WERE THE Result of CONCEPTIONS EaCH Season of the Year in the following Countries?

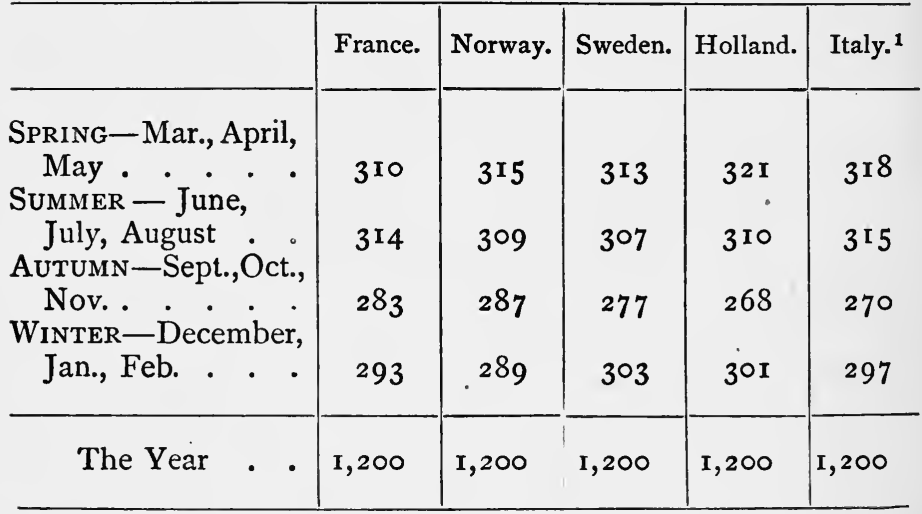

Legitimate births therefore appear to be slightly under the influence of seasons. The difference in reproduction proclivity is not great, but it is fairly suggestive of permanent influence.

More striking is the evidence of periodicity in the proclivity to those relationships which occasion illegitimate births. If in the earlier stages of human development out of animalism there did exist the stronger instincts of the brute, we might expect to find the traces to-

1 The figures for Italy are inclusive of both legitimate and illegitimate births. 
day wherever passion is more powerful than the respect due to custom, religion, and law.

Table IX.-Illegitimate Births. Of each I,200 ANNUALLY, HOW MANY WERE DUE TO CONCEPTIONS AT Different Seasons of the Year in the following Countries?

\begin{tabular}{|c|c|c|c|c|}
\hline & France. & Norway. & Sweden. & Holland. \\
\hline 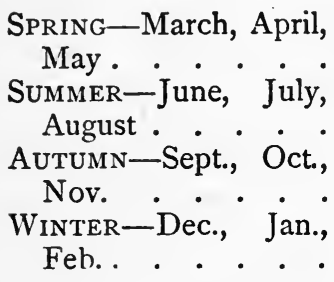 & $\begin{array}{l}321 \\
324 \\
275 \\
280\end{array}$ & $\begin{array}{l}298 \\
312 \\
292 \\
298\end{array}$ & $\begin{array}{l}315 \\
33^{8} \\
275 \\
272\end{array}$ & $\begin{array}{l}341 \\
304 \\
253 \\
302\end{array}$ \\
\hline & $I, 200$ & I, 200 & 1,200 & 1,200 \\
\hline
\end{tabular}

The phenomenon is even more notable if we compare the four months of April, May, June, and July, when the proclivity appears strongest, with the four months, October, November, December, and January, when it is least. 
Table X.-Of Each I, 200 Births Annually, how many WERE THE RESUlt OF CONCEPTIONS DURING TWO Periods OF Four MonThS EACH?

\begin{tabular}{|c|c|c|c|c|c|}
\hline & & \multicolumn{2}{|c|}{$\begin{array}{l}\text { Four months, April to } \\
\text { July. }\end{array}$} & \multicolumn{2}{|c|}{$\begin{array}{l}\text { Four months, October to } \\
\text { January. }\end{array}$} \\
\hline & & Legitimate. & Illegitimate. & Legitimate. & Illegitimate. \\
\hline France & & 429 & 446 & 384 & 365 \\
\hline Holland . & . & $43^{6}$ & 437 & 384 & 364 \\
\hline Sweden . & . & 421 & 443 & 389 & 349 \\
\hline Norway $^{1}$. & . & 425 & 419 & 397 & 396 \\
\hline
\end{tabular}

For Italy we are unable to make, as regards season, any distinction between legitimate and illegitimate births, so that I have not included it in the foregoing table. Taking all births together, however, Italy tells the same story. Per 1,200 annual births, the conceptions between April and July were 440, as contrasted with 379 for the four months October to January.

In Norway, too, the spring-time is long in coming, and its influence, as we should naturally

1 For Norway the four months of strongest tendency for illegitimate births are June to September. For the facts from which the last three tables have been made, see Dr. Bertillon's article "Natalite," in Dict. Enc. des Sciences Medicales. 
expect, is felt at a period considerably later than in other countries.

While there are no English statistics available which allow exact comparison with those mentioned for other nations, we are nevertheless given by the Registrar General the basis for what seems to me an exceedingly interesting curve diagram, in the quarterly birth-rate since 184I. Merely as figures they appear to have attracted no attention; but thrown into a diagram, the singular alternations from season to season are most strikingly evident. It appears that for the ten years $184 \mathrm{I}-50$ the average birth-rate in England and Wales for the first quarter of the year was 34.2 ; that for the second quarter it was 33.7 ; at once falling away for the last half of the year to an average of $3 \mathrm{I}^{\prime 2}$. Now see how regularly this phenomenon is repeated for the next forty years, and then how closely it compares with the experience of half a century. For the quarterly birth-rate in England and Wales for over fifty years forms a succession of similar waves, from season to season. 
Curve Diagram, showing for England and Wales THE Annual Birth-Rate to I,O00 Living, FOR Each Quarter of the Year, DURing Four TenYear Periods. ${ }^{1}$

\begin{tabular}{|c|c|c|c|c|}
\hline \multirow{2}{*}{$\begin{array}{l}\text { Birth } \\
\text { Rate. }\end{array}$} & $1841 \cdot 50$ & $1851-60$ & $1861-70$ & $1871-^{\prime} 80$. \\
\hline & 1234 & 1234 & 1234 & 1234 \\
\hline 37 & & & & \\
\hline 36 & & & & \\
\hline 35 & & $?$ & & \\
\hline 34 & & & & \\
\hline 33 & & & & \\
\hline 32 & & & & \\
\hline 31 & $\stackrel{!}{\prime}$ & & & \\
\hline 30 & & & & \\
\hline
\end{tabular}

We have thus a diagram based upon nearly thirty million births. It proves, I think,

1 The curve showing the birth-rate variations for more than half a century may be easily made by the reader on a sheet of ruled paper, from the following data. The average number of births during the first three months of the period I838-I889 was at the annual rate of $35 \mathrm{I}$ per ten thousand population; for the next three months, April to June, 349 ; while for the third quarter the rate was only 327 , and for the last quarter, 326. See Table 4, in Reg. Gen. Rep. for England and Wales for 1889. See also Table No. 15 in the 39th Annual Report of the Registrar General for year 1876 . 
beyond question the influence of the seasons upon the birth-rate in this country. Taken altogether, the facts seem to me almost definitely conclusive of the theory that as regards births, male or female, in city or country, legitimate or illegitimate, in countries as far apart as Italy and England or France and Sweden, the months of spring and summer mark on the human race a stronger propulsion toward what Schopenhauer calls "the will to live."

Marriage.-One would naturally expect to find the influence of season particularly noticeable upon the marriage rate. In a perfectly natural system of society, where the inclination or proclivity was free to turn undisturbed, it would be undoubtedly evident. It so happens, however, that religious and social customs intervene in most civilized countries, and create prejudices for, or against, the celebration of marriage during particular seasons of the year, - prejudices which of course have no basis in nature. For instance, in Catholic countries marriage must not take place during Lent; therefore in France and Italy the majority of nuptials are in February. In Ireland, particu- 
larly in the West and South,. more than half the Catholic marriages are celebrated between Christmas and Shrovetide. In some parts of Europe, Scotland for instance, there is a strong prejudice against marrying in May-a prejudice which Sir Walter Scott noticed in Malta, and mentions in his last journals. Nearly everywhere agricultural populations object to the season of harvest, and defer such ceremonies until October and November. In Russia more than three-fourths of all marriages occur in autumn and winter; a proportion altogether impossible unless some exceedingly strong local customs or religious prejudices did not interfere. No such prejudice appears in respect to criminal actions; it does not appear that intending suicides hesitate because it happens to be Lent. There is no doubt, I think, that an influence toward marriage is exerted by different seasons-an influence which is perceptible in several countries-but as a rule it is quite overwhelmed and repressed, or rather diverted, by considerations of policy, local prejudices, and the dictates of religion.

Upon the tendency to marital dissatisfaction, one might expect the influence of spring-time 
to be specially felt. Are elopements more common at this season? There are no figures, and of course no means of deciding the facts. In his valuable study of the divorce question, Dr. J. Bertillon has given the season of the years during which some 7,I 77 divorces were pronounced in France during the two years I 885-86. Of this number it appears that no less than 6I per cent. were obtained between April Ist and September 3oth of each year, leaving for the autumn and winter 39 per cent. Do these figures indicate to any extent the period of the year when divorce proceedings were initiated? If so, they accord with the general law. Usually, however, so much delay intervenes between the application for divorce and its concession, that little relation may exist between the time when desire for disunion first shaped action, and the time of the year. Still the coincidence is worth noting, and makes further observation desirable.

In other phases of conduct springing from emotional excitement we perhaps may detect in some slight degree the working of the general law. Duels, for instance, would not at first glance be taken as subject to any law of period- 
city. In Italy, nevertheless, it is found that they are far more common in spring and summer than in the other seasons, and particularly frequent in spring.

Popular insurrections, riots, outbursts of patriotic fervour, or revolutions, all are apparently more apt to occur in the spring and summer months. In Anerica, it has been noticed that the first armed resistance to British authority was made in April, I775, that the first pitched battle was fought in June, and that the decision to sever absolutely all allegiance to the mother country was adopted in July. It may some day be held doubtful whether that great wave of patriotic fury which swept over the Northern States at the firing upon Fort Sumter in April, I86I, could possibly have been evoked at the North during the chilly months of November and December. Four great riots in the city of New York, in 1849 , I857, I863, and I871, occurred during May, June, and July. In Paris, it was July that witnessed the attack upon the Bastille in 1789 , the fall of the Bourbons in 1830 , and that declaration of war with Prussia in 1870 which led to the overthrow of Napoleon III., while 
the great riot of June, I848, which overturned the Orleans dynasty, and the final scenes of the Commune in the closing days of May, I 8 T I-tragedies and atrocities which it almost seems as if civilization had conspired with history to forget-all these are in conformity with the influence of spring and summer on the passion toward violence. It will not do to push this part of the theory to absolute conclusions without a careful tabulation of all great historical insurrectionary movements and political outbreaks throughout the Northern Hemisphere, and for this I have no present leisure. But the instances given are certainly fairly representative of popular insurrectionary movements ; and if England has been omitted, it is only because riots are always unusual here. The last occasion of a great mob in London was the "No-Popery" riot of June, I780. Certainly, as a rule, so far as popular outbreaks are concerned, winter seems to be conservative in its influence, while spring and summer are full of passionate tendencies toward outbreak, whether of riot or revolution.

For a final comparison I have grouped together various phases of conduct, wherein 
Table XI.-OF Each thousand $(\mathrm{I}, 000)$ attacks of INSANITy OR CASE OF SUICIDE, CRIME, ETC., HOW MANY HAPPENEУ IN EACH HALF OF THE YEAR?

\begin{tabular}{|c|c|c|c|}
\hline Phases of Conduct or Disease. & 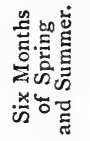 & 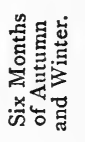 & $\begin{array}{l}\text { The } \\
\text { Year. }\end{array}$ \\
\hline 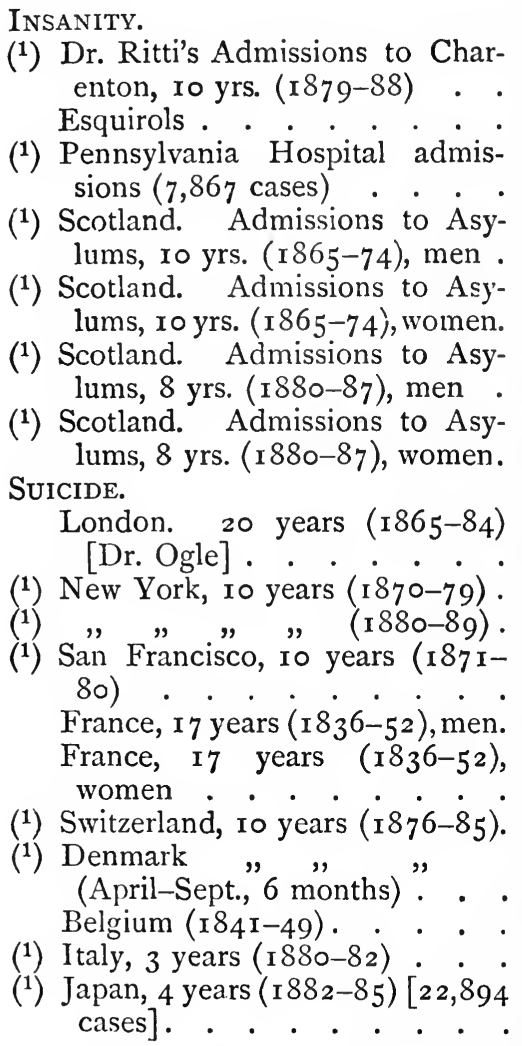 & $\begin{array}{l}55 \cdot 9 \\
55 \cdot 3 \\
54 \cdot 9 \\
52 \cdot 4 \\
58 \cdot 8 \\
\\
57 \cdot 9 \\
57 \cdot 4 \\
59 \cdot 5 \\
57 \cdot 6 \\
57 \cdot 6\end{array}$ & $\begin{array}{l}44^{\circ} \mathrm{I} \\
44^{\cdot} \cdot 7 \\
45^{\circ} \mathrm{x} \\
47^{\cdot} \cdot 6 \\
4^{\prime} \cdot 2 \\
4^{2} \cdot \mathrm{I} \\
4^{2} \cdot 6 \\
40^{\circ} \cdot 5 \\
4^{2} \cdot 4 \\
42 \cdot 4\end{array}$ & $\begin{array}{l}100^{\circ} 0 \\
100^{\circ} 0 \\
100^{\circ} 0 \\
100^{\circ} 0 \\
100^{\circ} 0 \\
100^{\circ} 0 \\
100^{\circ} 0 \\
100^{\circ} 0 \\
100^{\circ} 0 \\
100^{\circ} 0\end{array}$ \\
\hline
\end{tabular}




Phases of Conduct or Disease.

\begin{tabular}{|c|c|c|}
\hline 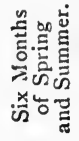 & 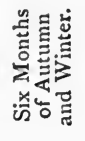 & $\begin{array}{l}\text { The } \\
\text { Year. }\end{array}$ \\
\hline & & \\
\hline $\begin{array}{l}58 \cdot 6 \\
61 \cdot 0\end{array}$ & $\begin{array}{l}4 x^{\circ} 4 \\
39^{\circ} \circ\end{array}$ & $\begin{array}{l}100^{\circ} \\
1000^{\circ}\end{array}$ \\
\hline 60.4 & $39^{\circ} 6$ & $100^{\circ}$ \\
\hline $54 \cdot 1$ & $45^{\circ} 9$ & $100^{\circ}$ \\
\hline $54 \cdot 9$ & $45^{\circ} I$ & $100^{\circ}$ \\
\hline $54: 0$ & $46{ }^{\circ}$ & $100^{\circ} 0$ \\
\hline $54: 9$ & $45^{\circ} \mathrm{I}$ & $100^{\circ}$ \\
\hline $53 \cdot 4$ & $46 \cdot 6$ & $1000^{\circ}$ \\
\hline $55 \cdot 0$ & $45^{\circ} \circ$ & $100^{\circ}$ \\
\hline $60 \cdot 1$ & $39^{\circ} 9$ & $100^{\circ}$ \\
\hline $62 \cdot 9$ & $37^{\circ} \mathbf{I}$ & $100^{\circ} 0$ \\
\hline 53.17 & $46 \cdot 3$ & $100^{\circ} 0$ \\
\hline $53 \cdot 7$ & $46 \cdot 3$ & $100^{\circ} 0$ \\
\hline $54 \cdot 5$ & 455 & $100^{\circ} 0$ \\
\hline $51 \cdot 8$ & $48 \cdot 2$ & $1000^{\circ}$ \\
\hline $52 \cdot 17$ & $47^{\circ} 3$ & $100^{\circ}$ \\
\hline 51.9 & $48 \cdot 1$ & $100^{\circ} 0$ \\
\hline
\end{tabular}

SUICIDE-continued.

(1) Japan, 3 years (1 886-88) [1 8, 204 cases].

Algiers, 4 years (1879-82) . .

(1) England and Wales, attempts at suicide (1878-1887) .

Homicide (including murderous assaults).

(1) England and Wales, 5 years (1878-82) . . . . . .

(1) England and Wales, 5 years CRIME. $(1883-87)$. . . . .

(1) England and Wales, crime agt. person, 5 years $(1878-82)$. .

(1) England and Wales, crime agt. person, 5 years (1883-87) . .

(1) Ireland, crime agt. person, ro years $(1878-87)$. . . .

France, crime agt. person, 40 years (1830-69)

(1) England and Wales, crimes agt. chastity, ro years ( $1878-87$ ) .

France, crimes agt. chastity, ro BirTHS. years (1860-69)

Illegitimate, France, $1856-65$. Holland, I860-69

" Sweden, I $86 \mathrm{I}-70$.

." Paris, $1856-65$.

Legitimate and illegitimate, Italy

Legitimate and illegitimate, England and Wales (5I years) .

See footnote on page 128 . 
statistics covering long periods of time show what is the preponderance of occurrence during spring and summer as compared with the remainder of the year. It is manifest to any one, that if no influence of the kind was in existence, the normal frequency of each phase of conduct for each half of the year would be exactly half, or 500 in each thousand cases during the year. In the preceding table I have included some statistics to which no previous reference in detail has been made. ${ }^{1}$

This list might be indefinitely extended, but here at least is enough to demonstrate that some force or influence disturbs the even distribution throughout the year of certain phases of conduct, and especially of conduct arising from passions which, in excess, are probably allied to madness. This preponderance is not very great, but it is constant, year after year. Perhaps we might even measure the potency of that inclination toward violent actions exerted by the warmer seasons; for it is about the difference between the highest and lowest

1 All statistics thus distinguished have been gathered by the author from the original official documents. In most cases the exact figures will be found in the Appendix. 
averages. During ten years for example, the number of Crimes against the Person, in England and Wales, during the first quarter of the year were 6,47 I, or an average for the year of about 25,800 . As a matter of fact the number was over 30,000. In Scotland again, during eighteen years the number of persons attacked with insanity during December was 2,97 I, and during January, 2,974. Now had the disease exhibited no greater rate of prevalence throughout the other months, more than 3,000 patients would have probably escaped the need for asylums in Scotland alone! But even immunity from insanity would be perhaps too dearly purchased at the cost of perpetual winters.

Are we justified in supposing that the intluence of season is limited only to crime, insanity, etc. ? If what we sometimes call the "unreasoning impulses" are pushed into undue activity as winter leaves us and the earth responds to solar influences, may not other actions, infinitely more numerous arise from the same cause? To one deed of crime, so serious as to call for the notice of the law, there are ten thousand acts of impetuous folly, of 
unreasoning anger, of jealousy, bad temper, and pugnacious proclivity. There can be no statistical record of them; yet they may ruin the happiness of a million homes. We can only appeal to individual experience. If attention were generally directed to the inquiry, we might find here, as well as elsewhere, that proclivity towards all passionate or emotional acts is strongest at certain seasons, in conformity with that general law, which then increases the frequency of insanity, vice, and crime.

What is the underlying cause of the phenomena I have grouped together? Admitting the facts, why does the cycle of the seasons thus affect the human will? How is it that at one time impulse is chilled with cold, and at another season heated into fierce activity?

The connection between the periodicity of attacks of insanity and proclivity toward suicide has more than once been suggested. If suicide be invariably the result of insane impulse, we can easily comprehend why the act of despair follows the course of the mental disease. As previously pointed out, attempts made to separate suicides of persons manifestly insane from others, have only resulted in discovering 
that both classes of self-destruction are alike subject to this annual ebb and flow.

I am nevertheless inclined to believe in the close relationship between the great mass of criminal, vicious, and passionate acts, arising from the violence of the emotions, and an unsound mental condition. It need not be that complex and completely abnormal state which we call "insanity." One of the principal lecturers on mental diseases in London, was accustomed to advise his pupils to avoid pronouncing upon the insanity of any one; it was far safer, he declared, to affirm that the patient affected was of "unsound mind," a term of great flexibility, and of corresponding utility. It may not be too much to assume that all violent and sudden outbursts of unreasoning rage, cruelty, lust, or jealousy, leading to actions which the perpetrator in sober moments bitterly regrets, are the effect of a mind temporarily unbalanced, and unsound. A mad man is a madman for the hour; he does not reason or reflect : he only feels; and even the certainty of retributive justice may not check the uplifted hand. The mentally unbalanced who sooner or later find themselves within the walls 
of an asylum or retreat are but a tithe of those who escape such control, and continue year after year to make miserable the lives of all dependent upon them. But even granting this connection between "insanity" and acts of passion, we have still to ascertain why such attacks of mental unsoundness vary with the seasons? What mysterious bond unites them all in one common perturbation at certain seasons of the year?

There is one hypothesis which seems to me capable of accounting for all the phenomena. It is this; that either by the gradual increase of solar light and solar heat, or else in some other manner quite mysterious at present, the breaking up of winter and the advent of spring and summer seasons, produces upon all animated nature a peculiar state of excitement or exaltation of the nervous system. Upon evidence not yet sufficient for demonstration, I am disposed to believe that one effect both in higher animals and in man is an actual increase in the quantity of blood sent through the system; or that the heart in reality beats at a quicker rate, with stronger impulse, in April and May, than in November and December. 
Now the physiological effect of this slightly increased nervous energy and sensibility manifests itself probably in different ways. In the first place everywhere in nature the advent of the warmer seasons signalizes the special aptitude of the creature for fertility and reproduction; and the facts I have brought forward appear to me to indicate that mankind does not escape an influence which thus affects alike the animal and vegetable world. Doubtless in many cases the influence is too slight to be subjectively noted; we can only discover the effect through statistics of conduct, in relation to the great mass of human beings, and by noting whether there is in truth any preponderance of phenomena at different seasons.

Again, a continuous and gradually increasing wave of excitability or nervous exaltation affecting the entire human race in any given latitude would undoubtedly give rise to emotional manifestations, leading to action. Probably there are few of us who have not at certain times experienced a strange tendency to melancholy retrospect, a vague restlessness, an undue depression of spirits, or an irritability and discontent without apparent cause. Whether conduct 
thus incited shall be grood or bad, generous or selfish, vicious or virtuous, will in all cases principally depend on individual character and organization. To humanity in the highest type of development, perhaps even to the Race as a whole, this exacerbation of emotional life with the opening year does no harm; on the contrary, it is the source of sentiment, the occasion of poetry, the inspiration in gentle natures of the purest and most reverential love, or in noble souls of patriotic resistance to oppression and tyranny. But that which upon the great mass of mankind evinces itself in perfectly normal ways, may have a far different effect upon the ungovernable temper, the uncontrolled appetite, the jealous suspicions of unsound minds. Discontent with environment becomes then transformed, it may be, into desire for death, and the thought of suicide. Disappointed love may then lead to a fixed melancholy, or anxiety and trouble to the delusion of despair, and we then say that a wave of insanity passed over us. The brutal lusts, the selfish and pugnacious instincts of the half-civilized barbarians in our great cities, may need only the incitement of opportunity to induce the 
trampling under foot of all moral restraints ; and we note the increase of crimes of lust and resentment, or of murders and assaults with intent to kill. Like the magnetic needle, the will trembles toward every impulse; and when brutal propensities are uncontrolled, even slight causes may be sufficient to decide the sway and determine the action. For it depends where one stands whether he shall feel even the strongest of impulses in the physical world. The earthquake that laid Lisbon in ruins was noticed by the peasants working in their vineyards a hundred miles away only as a slight, tremulous thrill.

The hypothetical connection between certain phases of conduct may, perhaps, be brought more distinctly before the mind of the reader by the soheme on the following page.

Misapprehension in regard to any unfamiliar theory is almost certain to occur. It took many years for popular comprehension to understand that the Darwinian hypothesis did not mean the lineal and direct descent of men from monkeys. It cannot therefore be too clearly stated that cosmic influence upon human conduct is always very slight when we take into 
Theory of Relation between Solar Influences and Human Conduct.

\begin{tabular}{|c|c|c|c|}
\hline $\begin{array}{c}\text { I. } \\
\text { Solar Influences. }\end{array}$ & \begin{tabular}{|c|} 
II. \\
Physical results \\
upon M en and \\
Animals.
\end{tabular} & $\begin{array}{l}\text { III. } \\
\text { Mental and Physical } \\
\text { conditions arising } \\
\text { from II. }\end{array}$ & $\begin{array}{l}\text { IV. } \\
\text { Slight preponderance of } \\
\text { certain phases of con- } \\
\text { duct or disease in Spring } \\
\text { and Summer produced } \\
\text { thereby. }\end{array}$ \\
\hline $\begin{array}{l}\text { Gradually in- } \\
\text { creasing } \\
\text { LIGHT and } \\
\text { HEAT } \\
\text { OF } \\
\text { SPRING } \\
\text { AND } \\
\text { SUMMER. }\end{array}$ & $\begin{array}{l}\text { II. EXCITA- } \\
\text { TION OF THE } \\
\text { NERVOUS } \\
\text { SYSTEM. }\end{array}$ & $\begin{array}{l}\text { I. Emotional exalt- } \\
\text { ation. } \\
\text { 2. Increased ten- } \\
\text { dency toward } \\
\text { the reproduc- } \\
\text { tive instinct. } \\
\text { 3. Increased ten- } \\
\text { dency toward } \\
\text { Jealousy. } \\
\text { 4. Increased com- } \\
\text { bativeness and } \\
\text { pugnacity. } \\
\text { 5. Increased irrita- } \\
\text { bility of disposi- } \\
\text { tion and temper } \\
\text { 6. Sentimentality. } \\
\text { 7. Mental depres- } \\
\text { sion. } \\
\text { 8. Enthusiasm for } \\
\text { change. }\end{array}$ & $\begin{array}{l}\text { I. Birth-rate, legi- } \\
\text { timate. } \\
\text { 2. Birth-rate, illegi- } \\
\text { timate. } \\
\text { 3. Crimes of sex- } \\
\text { passion. } \\
\text { 4. Marriage rate? } \\
\text { 5. Divorces. } \\
\text { 6. Murders. } \\
\text { 7. Assaults. } \\
\text { 8. Duels. } \\
\text { 9. Riots. } \\
\text { 10. Attacks of in- } \\
\text { sanity. } \\
\text { 1. "Love affairs?" } \\
\text { 12. Suicide. } \\
\text { 13. Attempts at sui- } \\
\text { cide. } \\
\text { 14. Revolutions. }\end{array}$ \\
\hline
\end{tabular}

account the totality of action in any direction. What appears to me clear is its existence as a true factor of causation-no matter to how slight an extent. Only by some theory of the kind do I see how we are to explain phenomena of life-such for instance as the birthrate, and suicide-which have no conceivable relation to each other, and yet which alike preponderate at certain seasons of the year. 
But even if true, what is the use of knowing it ? No greater use, perhaps, than in other interrogations of Nature; in the study of the habits of an earth-worm, the flight of a swallow, or the parallax of a star. Yet I fancy there is always a potential value in facts.

Of their relation to life, animals must always remain in ignorance; but to human beings the knowledge which future investigation of these questions may more completely attain - that they are periodically subject to influences, dangerous oftentimes in their final effect upon conduct-cannot be wholly valueless. And besides this, there seems to me something so profoundly wonderful in the secrets of Nature and the uniformity of natural laws, that I envy no one whose emotions are never touched by that sense of mystery which underlies all reverence and love. One summer's day the opportunity was mine to look through a telescope at a large spot on the sun. Into that dark chasm our planet might drop, without even touching the edge of flame on either side. That may yet be its fate. But even now, it is not impossible that what we call "a mere sunspot" in midsummer may have some influence, 
in our little world, upon the ebb and flow of passion, the excitement of emotion, and all that makes up the profound mystery of human life. 


\section{APPENDIX I.}

\section{EXTRACTS.}

\section{ILLEGITIMACY IN ENGLAND.}

No one can have taken any interest in the workingclasses without being aware how frightfully common among them is what they term "a misfortune;" how few young women come to the marriage altar at all, or come there just a week or two before maternity, or having already had several children, often only half-brothers and sisters. *** It is easy for tenderly reared young ladies who study human passions through Miss Austen or Miss Edgeworth to say, "How shocking! Oh, it can't be true!" But it is true, and they will not live many more years without finding it true.

Another fact, stranger still to account for, is, that the women who thus fall are by no means the worst of their station. I have heard it affimmed by more than one lady, and by one in particular whose experience is as large as her benevolence, that many of them are of the very bestrefined, intelligent, truthful, and affectionate.

"I don't know how it is," she would say, "whether their very superiority makes them dissatisfied with their own rank, so that they fall easier victims to the rank above them, or whether other virtues can exist and flourish entirely distinct from, and after the loss of what we are accustomed to believe the indispensable virtue of our sex,-Chastity. I cannot explain it ; I can only say that it is so-that some of my most promising village girls have been the first to come to harm; and some of the best and most faithful 
servants I ever had have been girls who have fallen into shame, and who, had I not gone to the rescue, and put them on the way to do well, would invariably have become lost zomen."

Had she not "come to the rescue." Rescue, then, is possible, and they were capable of being rescued. [" $\mathrm{A}$ Woman's Thoughts about Women," by Miss Mulock, Author of "John Halifax, Gentleman."]

Immorality (in Hayti) is so universal that it almost ceases to be a fault, for a fault implies an exception, and in Hayti it is the rule. Young people make experiment of one another before they will enter into any closer connexion. So far they are no worse than in our own English Islands, where the custom is equally general. [Froude's "History of English in West Indies," p. 344.]

\section{ILLEGitimaCy IN SCOTLAND.}

In Scotland, incontinency subjects the offending parties to ecclesiastical measures. The ministers and elders of a parish call before them the mothers and the putative fathers (when discovered) of all illegitimate children, admonish them seriously for their conduct, and exclude them from participation in the ordinance of bread and wine until they have expressed contrition for their offence. [Rep. of Poor Law Commissioners to Sir G. Gralıame, I844.]

In a paper read by Dr. Stark, upon the Vital Statistics of Scotland, the writer gave the result of an inquiry into Illegitimacy in certain parishes of that country. "In seventynine parishes there were among the members of the Established Church 4,305 births, and of these 328 were illegitimate!" [" Journal of the Statistical Society," Vol. I4.]

NoTE. -That is a rate of 78 per 1000, higher than that of France or Italy. 


\section{Peasant Morality in Denmark.}

With regard to the peasant population of the rural districts . . . it was found that of a hundred first-born children no less than thirty-nine were born under seven months after marriage, to which must be added nine (9) per cent. born between seven and nine months after marriage. A great number of the brides who were not pregnant at marriage had already had illegitimate children with the bridegroom or others ; so that it may probably be assumed that in twothirds of the marriages (childless marriages excepted) the bride had had children while unmarried, or was pregnant at the marriage. ["Westergaard on Marriage Statistics of Denmark," Copenhagen. Translation furnished to Seventh International Congress of Hygiene and Demography.]

\section{Child Murder.}

An inquest was held before Mr. Braxton Hicks, at the Star and Garter, Battersea, concerning the death of a female child whose body was found in the Thames. Dr. Kempster stated that he saw the body at the mortuary, and had made a post mortem examination. The bones of the skull had been fractured all over, and the nose was flattened on the face. The injuries were inflicted while the child was alive, and they were the cause of death. The Coroner: "I think we have had about ten similar cases, have we not?" Dr. Kempster: "Yes; all killed in the same way." The Coroner : "In these cases as soon as a child is born its head is knocked all to pieces, and the body then thrown into the river." The jury returned a verdict of "Wilful murder against some person or persons unknown." [London Times, February 5, 1891.]

Distressing Suicide.-A well-dressed young woman was found lying on a seat at Rugby Station, Tuesday night. 
She had evidently taken some carbolic acid from a bottle which was by her side. Death ensued in half an hour. A number of letters were found in her possession, some signed "Your loving husband, Jack —.."

Dr. Wynter held an inquest on the body of the young woman who committed suicide at Rugby Station. A young man named Allen, employed as a cook at Oxford, stated that last summer the deceased and himself were living at Douglas, Isle of Man. In September they left Douglas, and for over a fortnight they lived together as husband and wife at the deceased's parents', the girl's relatives thinking they were married. Dr. Simpson expressed the opinion that the deceased was enceinte. The jury returned a verdict of "Suicide while temporarily insane." The Coroner, addressing Allen, said that though he was not legally responsible for her death, he was morally responsible. He lived with her in a barefaced manner as her husband, and then deserted her, and in her distracted condition she took her life. [Oxford Chronicle, January 31st, I89r.]

Note.-In the State of New York, by thus living "with her in a barefaced manner as her husband," and acknowledging that relation to her parents, this man would have become her legal husband without further ceremony.

Cruel Treatment of a Child.-At the Denbighshire Assizes yesterday, before Justice Lawrence, Catherine Roberts, aged 30 years, a charwoman, of Abergele, was charged with murdering her illegitimate female child, aged seven years. The medical evidence went to show that the child had been subjected to a long treatment of ill-usage, there being no less than 86 bruises on her body. Witnesses were called, and deposed to seeing the accused throw the deceased over a stile, whilst on another occasion it was alleged she beat the girl with a stick. When examined, 
there was not the slightest trace of food in the stomach of the deceased.-The jury found the prisoner "Guilty of manslaughter," and she was sentenced to twenty years' imprisonment. [Daily Nerus, July 23rd, I89r.]

At Stratford Petty Sessions, Annie Smith, 2 I, a respectably-dressed person, described as a servant of Quarry Cottage, Coursley Wood, Wadhurst, Sussex, was charged with attempting to drown her child, Charles Smith, aged one month, by throwing it into a ditch on Wanstead Flats. Joseph Wood, of 28, Francis Street, Stratford, the manager of a working-men's home, said that at about a quarter to 6 o'clock on Thursday evening he was going towards Forestgate across Wanstead Flats, when he saw the prisoner coming along the road. She had a baby in her arms. She passed him, and when he had gone a little way, he turned round and looked back. He then saw the prisoner go down a bank. She still had the baby in her arms. She took a cloak off the baby and put it (the cloak) on the grass, and then she disappeared from his sight. Soon afterwards she came up the bank again and went across the road. Then she ran towards Epping Forest. He ran after her, and when he got up to her, he asked her what she had done with the child. She said, "I have thrown it into the ditch." He said, "You had better come back with me while I get the child out," and she walked back with him until they came to the spot where she had disappeared. He then saw the child, and at once went across the ditch and got it out of the water. $\mathrm{He}$ thought there were between three and four feet of water in the ditch. The child was lying in the water, floating, with its hands up. He got hold of one of its hands to pull it out. Then he patted it on the back to get the water out of it. Giving it 
to the prisoner, he took her to the Leyton Police-station, and there she was charged. Prisoner was remanded. [The Times, February 14th, 189I.]

Yesterday, at Northampton, before Mr. Justice Vaughan Williams, Emily Scott, aged 20 , a domestic servant, was charged with the murder of her infant child. Mr. Sills and Mr. Perceval Keep, instructed by the Solicitor to the Treasury, appeared for the prosecution; and the prisoner was defended by Mr. Toller. It appeared that on the 8th of June last the prisoner, who had for two years been in the service of Mrs. Bird, at Welford, had done a hard day's work, but in the evening she complained of feeling ill, and went to bed early. Shortly afterwards her mistress went up to her room and found her very ill. A doctor was sent for, and he discovered in a cupboard the body of a fully grown female child, which had been newly born. The body was wrapped in an apron, the strings of which were drawn round the neck of the child, and a handkerchief was stuffed into its mouth. It was placed just inside the cupboard, which was closed, but not locked. The medical evidence showed that, although in the opinion of the doctor the death of the child had been caused by the handkerchief and apron strings, it was impossible for him to say whether it had had a separate existence or not. Upon this evidence the charge of murder was abandoned by the prosecution, and the case was left to the jury on the question of concealment of birth. The jury found the prisoner Not Guilty, and she was discharged! [The Times, July and, r89r.]

\section{Ancestry of President Lincoln.}

On the subject of his ancestry and origin I only remember one time when Mr. Lincoln ever referred to it. It was about 1850 , when he and I were driving in his one-horse 
buggy to the court in Menard county, Illinois. The suit we were going to try was one in which we were likely, either directly or collaterally, to touch upon the subject of hereditary traits. During the ride he spoke, for the first time in my hearing, of his mother, dwelling on her characteristics, and mentioning or enumerating what qualities he inherited from her. He said, among other things, that she was the illegitimate daughter of Lucy Hanks and a well-bred Virginia farmer or planter; and he argued that from this last source came his power of analysis, his logic, his mental activity, his ambition, and all the qualities that distinguished him from the other members and descendants of the Hanks family. His theory in discussing the matter of hereditary traits had been that, for certain reasons, illegitimate children are oftentimes sturdier and brighter than those born in lawful wedlock; and in his case, he believed that his better nature and finer qualities came from this broad-minded, unknown Virginian.

During and after the Presidential campaign of 1860 , Lincoln repeatedly refused to furnish any details regarding his progenitors. ["Herndon's Life of Abraham Lincoln."] 


\section{APPENDIX II.}

On the Value of Statistics.

"It is hardly possible to overrate the value of figures, partly by checking that universal tendency to exaggeration -not wilful, but a kind of mental illusion-which operates wherever we are deeply interested; partly as giving definiteness and precision to ideas which otherwise would remain floating in our minds in a vague, and therefore comparatively useless, form.

"When you find uniformity, or something which closely approximates to uniformity, it is impossible not to be impressed with the permanence and steadiness of the laws which regulate our existence." [Lord Derby, before the British

Association.] 


\section{Illegitimacy in EUROPE.}

Of each 1000 Births (still-births excluded) during years mentioned, how many were illegitimate in the following countries?

\begin{tabular}{|c|c|c|c|c|c|c|c|c|c|c|c|}
\hline & & & & & 1869. & 1870. & 1885. & I886. & 1887. & 1888. & x889. \\
\hline Ireland. & . & . & - & . & 29 & 27 & 28 & 27 & 28 & 29 & 28 \\
\hline Russia . & . & . . & . & & 28 & 28 & 28 & 27 & 28 & 27 & 27 \\
\hline Holland & & . . & . & . & 36 & 35 & $3 I$ & 32 & $3^{2}$ & $3 I$ & 33 \\
\hline Switzerlan & $d^{*}$ & . . & & & - & - & 50 & 49 & 48 & 48 & 47 \\
\hline England a & ind & Wale & & & 58 & 56 & 48 & 47 & 48 & 46 & 46 \\
\hline Spain . & . & . . & & & 56 & 55 &.- & - & - & - & - \\
\hline Italy . & . & . & 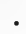 & & 60 & 64 & 76 & 75 & 75 & 74 & 73 \\
\hline France. & . & - & . & $\bullet$ & 75 & 75 & 80 & 82 & 82 & 85 & 84 \\
\hline Belgium & . & . & & & 71 & 72 & 87 & 87 & 88 & 87 & 88 \\
\hline Prussia * & . & . & & & 78 & 79 & 82 & 82 & 82 & 80 & 80 \\
\hline Hungary & . & . & & & 70 & 68 & 84 & 83 & 84 & 84 & 85 \\
\hline Scotland & . & . . & & & 98 & 96 & 85 & 82 & 83 & 81 & 79 \\
\hline Norway. & - & - & • & - & 85 & $9 I$ & 79 & 79 & 77 & 76 & 74 \\
\hline Denmark & . & . & . & $\bullet$ & 114 & I I I & 100 & 97 & 97 & 93 & 93 \\
\hline Sweden & - & . . & . & . & 102 & 104 & 104 & 102 & 105 & 102 & rOI \\
\hline Saxony. & - & - & . & & 136 & 137 & 130 & 129 & I 28 & 125 & 125 \\
\hline Pavaria * & . & . & . & - & 179 & 164 & I39 & I 39 & 138 & 140 & $14 I$ \\
\hline Austria. & - & . & - & - & 138 & I 3 I & 147 & 147 & I 47 & 146 & I 47 \\
\hline
\end{tabular}

* Including Still Births for 1885-89.

NotE. - In the above table are grouped together the latest available statistics for the principal countries of Europe. For purposes of comparison the illegitimate birth-rate of twenty years ago is also given, and the reader will thus be able to see the differences between the races of Europe, and to note to what extent the present tendency of each nationality is toward increase or decrease of its illegitimate births. 


\begin{tabular}{|c|c|c|c|c|}
\hline 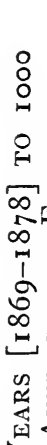 & 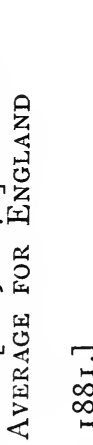 & 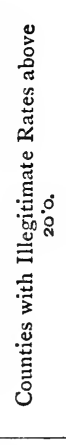 & 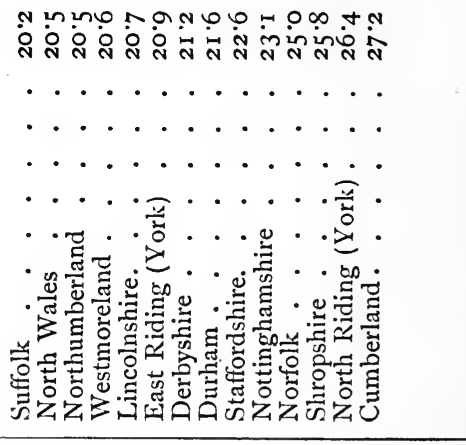 & 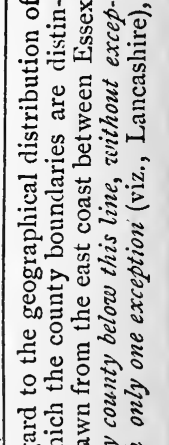 \\
\hline 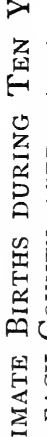 & 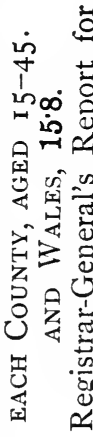 & 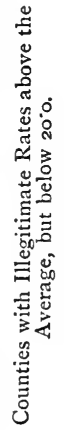 & 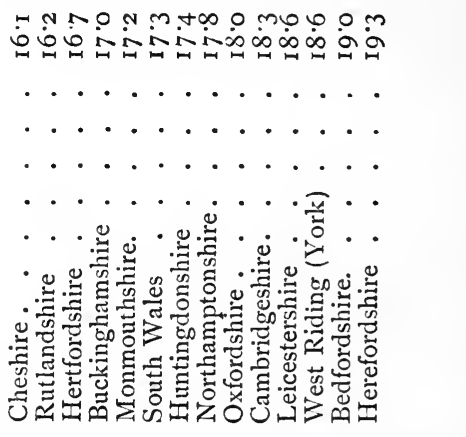 & 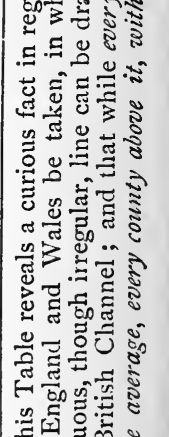 \\
\hline 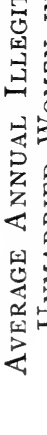 & 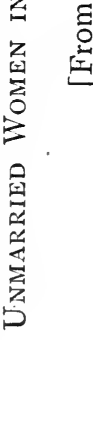 & 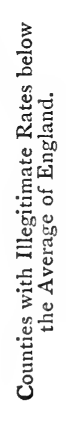 & 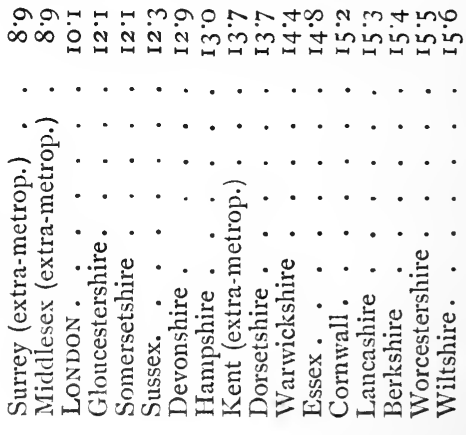 & 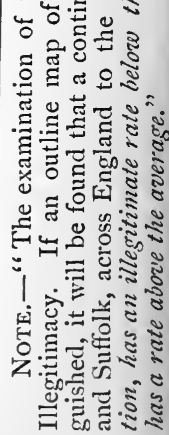 \\
\hline
\end{tabular}




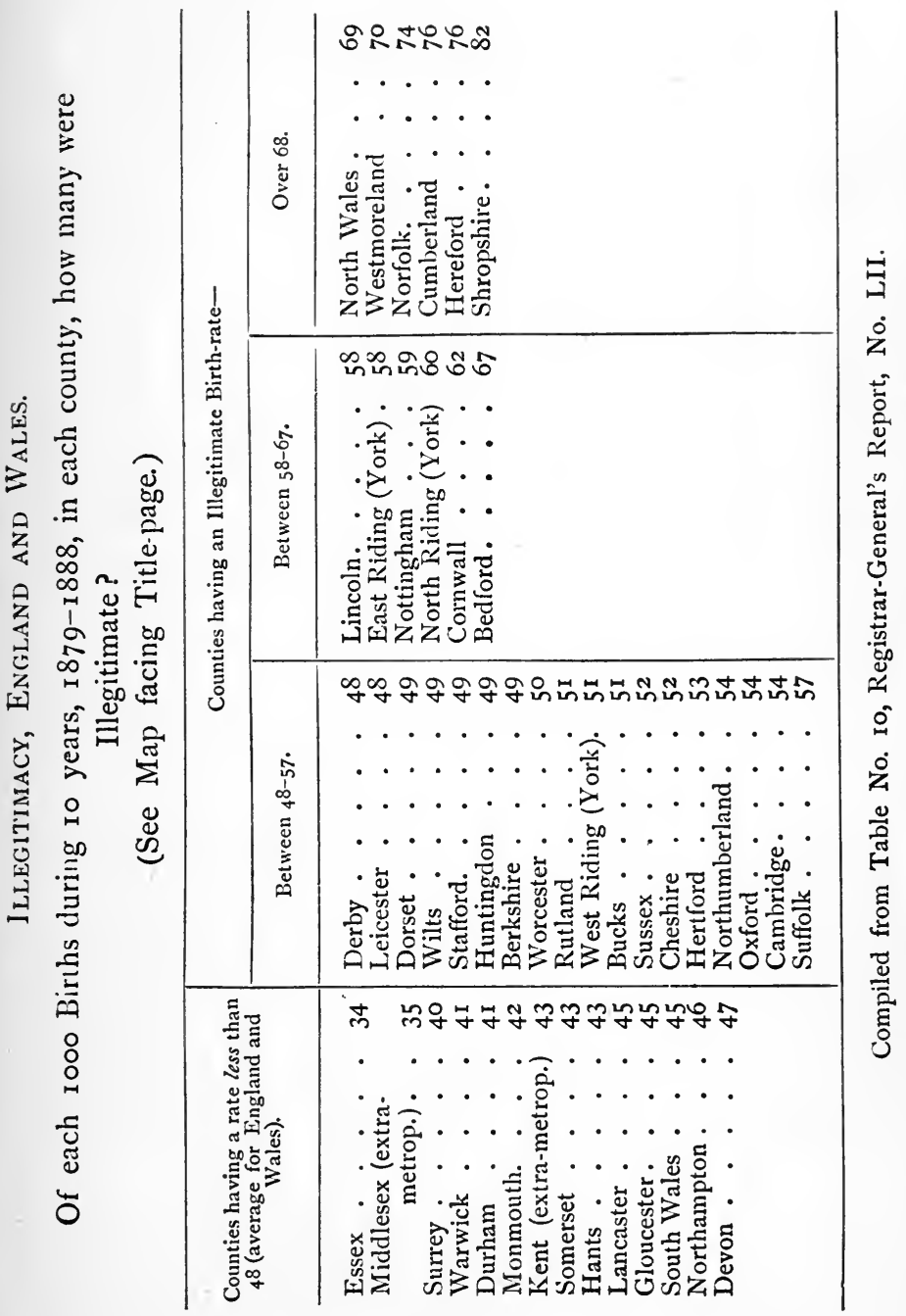




\section{Illegitimate Births in Cities of England.}

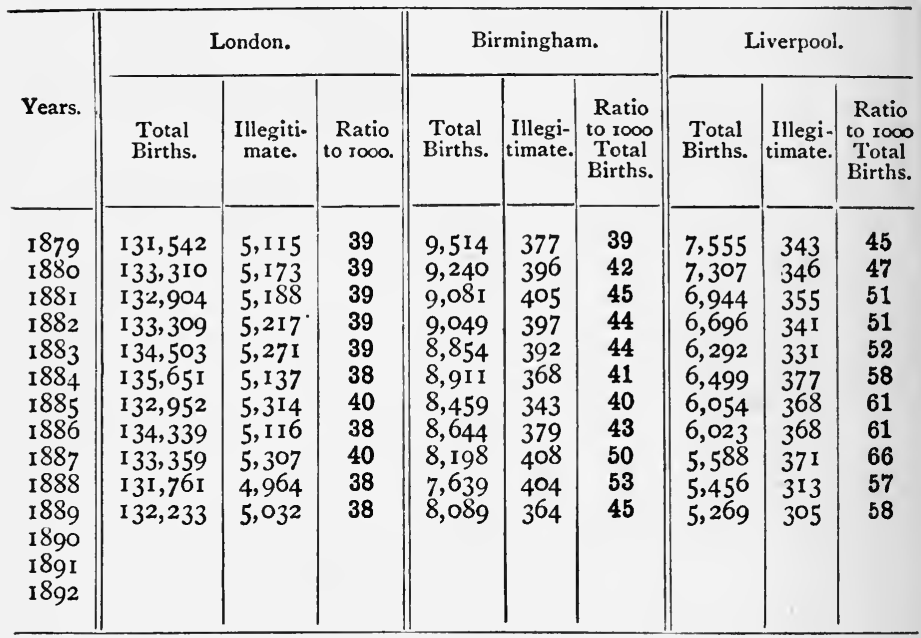

\section{ILLEGITIMACY IN LONDON.}

Of each thousand births in the following districts and subdistricts, how many were illegitimate?

\begin{tabular}{|c|c|c|c|c|c|c|c|c|c|}
\hline & 1875 & $188_{3}$ & 1884 & 1885 & I886. & 1887 & I 888. & x889. & 1890. \\
\hline $\begin{array}{l}\text { Whitechapel } \\
\text { Marylebone. } \\
\text { Sub- }\left\{\begin{array}{l}\text { Kectory : } \\
\text { St. Mary. }\end{array}\right. \\
\text { districts } \\
\text { ALL LoNDON - }\end{array}$ & $\begin{array}{r}28 \\
115 \\
216 \\
276 \\
38\end{array}$ & $\begin{array}{r}34 \\
146 \\
213 \\
370 \\
39\end{array}$ & $\begin{array}{r}35 \\
166 \\
239 \\
399 \\
38\end{array}$ & $\begin{array}{r}31 \\
180 \\
287 \\
414 \\
40\end{array}$ & $\begin{array}{r}34 \\
168 \\
220 \\
410 \\
38\end{array}$ & $\begin{array}{r}26 \\
178 \\
240 \\
413 \\
40\end{array}$ & $\begin{array}{r}29 \\
158 \\
197 \\
382 \\
38\end{array}$ & $\begin{array}{r}30 \\
172 \\
275 \\
394 \\
38\end{array}$ & $\begin{array}{r}27 \\
168 \\
247 \\
406 \\
38\end{array}$ \\
\hline
\end{tabular}

NстE. - It will be seen from this table that in one part of London (St. Mary, Marylebone) the rate of illegitimacy is annually over one-third of all the births. The contrast between Whitechapel and Marylebone is noteworthy. 


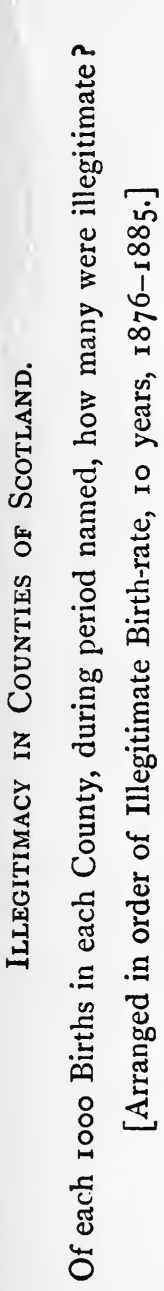

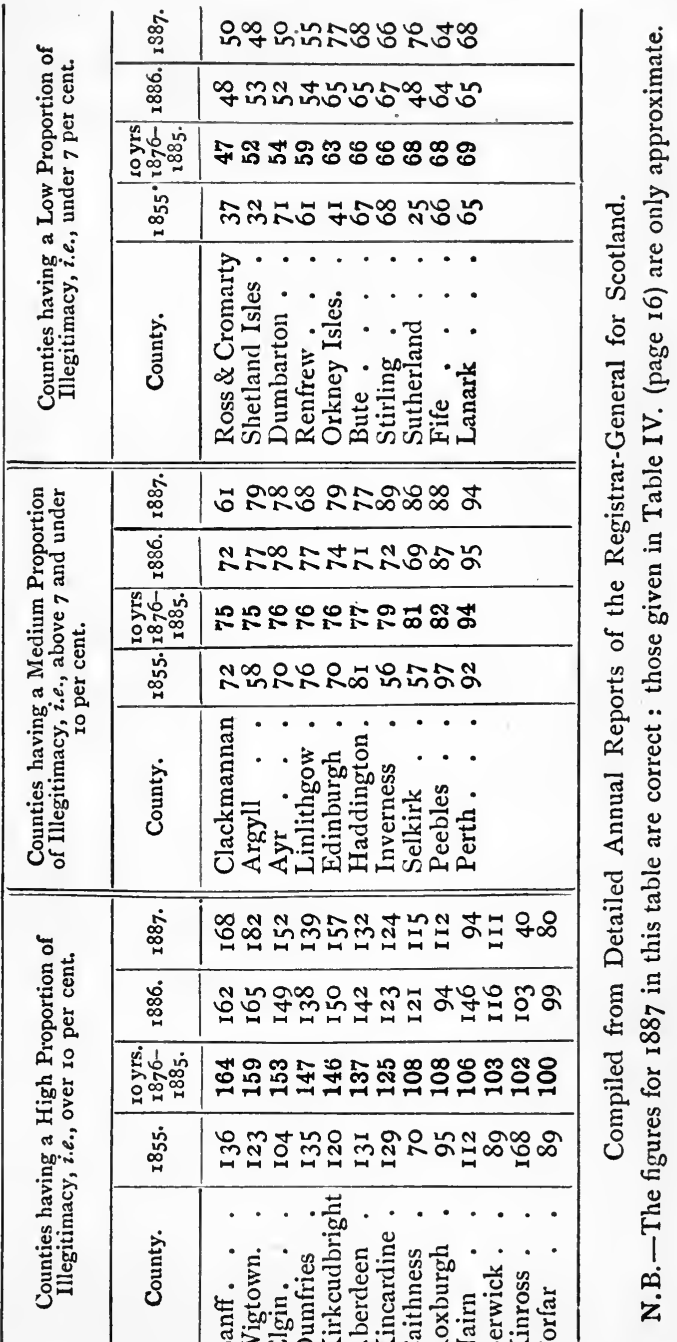




\section{Illegitimacy in Principal Cities of Scotland. [From Registrar General's Reports.] \\ Number of Illegitimate Births in proportion :}

\begin{tabular}{|c|c|c|c|c|c|c|c|c|}
\hline & \multicolumn{4}{|c|}{ To rooo Total Births. } & \multicolumn{4}{|c|}{$\begin{array}{l}\text { To rooo Unmarried Women between } \\
15-45 .\end{array}$} \\
\hline & $\begin{array}{l}\text { Aber- } \\
\text { deen. }\end{array}$ & Dundee. & $\begin{array}{l}\text { Edin. } \\
\text { burgh. }\end{array}$ & $\begin{array}{l}\text { Glas- } \\
\text { gow. }\end{array}$ & $\begin{array}{l}\text { Aber- } \\
\text { deen. }\end{array}$ & Dundee. & $\begin{array}{c}\text { Edin- } \\
\text { burgh. }\end{array}$ & $\begin{array}{l}\text { Glas- } \\
\text { gow. }\end{array}$ \\
\hline $1873-1882$ & & & & & & & & \\
\hline (Io yrs.) & I 12 & 107 & 82 & 82 & - & 一 & - & 一 \\
\hline $188_{3}$ & 98 & 108 & 88 & $8 I$ & 23 & 21 & 15 & 24 \\
\hline I 884 & 103 & 100 & 79 & 79 & 24 & $2 I$ & 14 & 24 \\
\hline I 885 & 109 & I IO & 90 & 82 & 26 & $2 I$ & I6 & 24 \\
\hline I886 & I I 4 & IOI & 83 & 78 & 28 & 19 & 14 & 23 \\
\hline 1887 & 106 & 104 & 85 & 83 & 24 & 18 & 15 & 23 \\
\hline
\end{tabular}

Illegitimacy AND Age of Mothers.

Of total illegitimate births in England and Wales during the year 1902, how many were the first-born children of mothers at each age, and of either social condition?

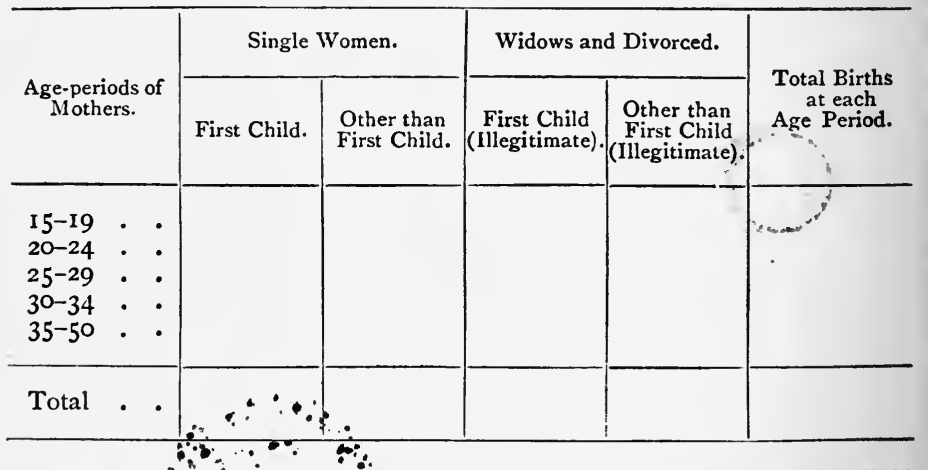

NOTE.-This is merely a suggestion for a statistical table which should indicate the reqution between illegitimate births and the ages of the mothers. No facts of thi kind are at present anywhere to be obtained. 
Illegitimacy in CERTAin COUNTIES OF IRELAND, DURING TeN YEARS, I 879-1888.

[Compiled from Reports of the Registrar-General.]

\begin{tabular}{|c|c|c|c|c|c|}
\hline \multirow[b]{2}{*}{ County. } & \multirow{2}{*}{$\begin{array}{l}\text { Total No. all } \\
\text { Births (18 } 899- \\
\text { 1888.) Ten } \\
\text { Years. }\end{array}$} & \multirow{2}{*}{$\begin{array}{c}\text { Total Unmarried } \\
\text { Females (15-45) } \\
\text { at Census of } \\
\text { 1881. }\end{array}$} & \multirow{2}{*}{$\begin{array}{c}\text { No. of } \\
\text { Illegitimate } \\
\text { Births } \\
\text { (Ten Years.) }\end{array}$} & \multicolumn{2}{|c|}{$\begin{array}{l}\text { Rate of Illegiti- } \\
\text { macy. }\end{array}$} \\
\hline & & & & $\begin{array}{c}\text { To rooo } \\
\text { Total } \\
\text { Births. }\end{array}$ & $\begin{array}{l}\text { To each } \\
\text { ro,ooo } \\
\text { Unmarried } \\
\text { Women } \\
\text { (15-45). }\end{array}$ \\
\hline $\begin{array}{l}\text { Mayo, Connaught } \\
\text { Sligo, ", } \\
\text { Galway, ", }\end{array}$ & $\begin{array}{l}57,141 \\
20,249 \\
53,215\end{array}$ & $\begin{array}{l}29,069 \\
11,649 \\
27,655\end{array}$ & $\begin{array}{l}322 \\
163 \\
556\end{array}$ & $\begin{array}{r}5 \\
8 \\
10\end{array}$ & $\begin{array}{l}\text { II } 7 \\
14 \\
20\end{array}$ \\
\hline $\begin{array}{l}\text { Donegal, Ulster } \\
\text { Tyrone, ," } \\
\text { Lundonderry, ", } \\
\text { Down, ", } \\
\text { Antrim, ", }\end{array}$ & $\begin{array}{r}42,887 \\
40,170 \\
39,164 \\
60,346 \\
122,585\end{array}$ & $\begin{array}{l}28.503 \\
32,002 \\
27,259 \\
34,330 \\
69,593\end{array}$ & $\begin{array}{r}670 \\
1,666 \\
1,790 \\
3,084 \\
6,583\end{array}$ & $\begin{array}{l}16 \\
41 \\
46 \\
51 \\
52\end{array}$ & $\begin{array}{l}23 \cdot 5 \\
52 \\
66 \\
90 \\
94^{\circ} 6\end{array}$ \\
\hline $\begin{array}{l}\text { Kerry, Munster } \\
\text { Clare ", } \\
\text { Limerick ", }\end{array}$ & $\begin{array}{l}48,624 \\
29.749 \\
42,300\end{array}$ & $\begin{array}{l}21,721 \\
15,851 \\
25,501\end{array}$ & $\begin{array}{r}691 \\
443 \\
1,148\end{array}$ & $\begin{array}{l}14 \\
15 \\
27\end{array}$ & $\begin{array}{l}32 \\
28 \\
45\end{array}$ \\
\hline AlL IRELAND & $1,200,782$ & 731,767 & 31,856 & $26 \cdot 5$ & 43.5 \\
\hline
\end{tabular}


England Wales. Coroners' Inquests on INFANTS I Year OLD AND UNDER.

\begin{tabular}{|c|c|c|c|c|c|c|}
\hline \multirow{2}{*}{. } & \multicolumn{3}{|c|}{ Legitimate. } & \multicolumn{3}{|c|}{ Illegitimate. } \\
\hline & Boys. & Girls. & Both. & Boys. & Girls. & Both. \\
\hline $\begin{array}{l}\text { I } 88 \text { I } \\
\text { I } 882 \\
\text { I } 883 \\
\text { I } 884 \\
\text { I } 885 \\
\text { I } 886 \\
\text { I } 887\end{array}$ & $\begin{array}{l}2,171 \\
2,222 \\
2,354 \\
2,359 \\
2,323 \\
2,482 \\
2,561\end{array}$ & $\begin{array}{l}1,887 \\
1,943 \\
2,029 \\
1,969 \\
1,962 \\
2,009 \\
2,224\end{array}$ & $\begin{array}{l}4,058 \\
4,165 \\
4,383 \\
4,328 \\
4,285 \\
4,491 \\
4,785\end{array}$ & $\begin{array}{l}545 \\
482 \\
498 \\
560 \\
583 \\
541 \\
555\end{array}$ & $\begin{array}{l}481 \\
428 \\
449 \\
481 \\
438 \\
534 \\
488\end{array}$ & $\begin{array}{r}\mathrm{I}, 026 \\
910 \\
947 \\
\mathrm{I}, 04 \mathrm{I} \\
\mathrm{I}, 02 \mathrm{I} \\
\mathrm{I}, 075 \\
\mathrm{I}, 043\end{array}$ \\
\hline $\begin{array}{l}\text { Total Inquests } 7 \text { years } \\
\text { No. of Inquests to each } \\
\text { Iooo born of either } \\
\text { class . . . . . }\end{array}$ & 16,472 & 14,023 & $\begin{array}{c}30,495 \\
5\end{array}$ & 3,764 & 3,299 & $\begin{array}{c}7,063 \\
24\end{array}$ \\
\hline
\end{tabular}




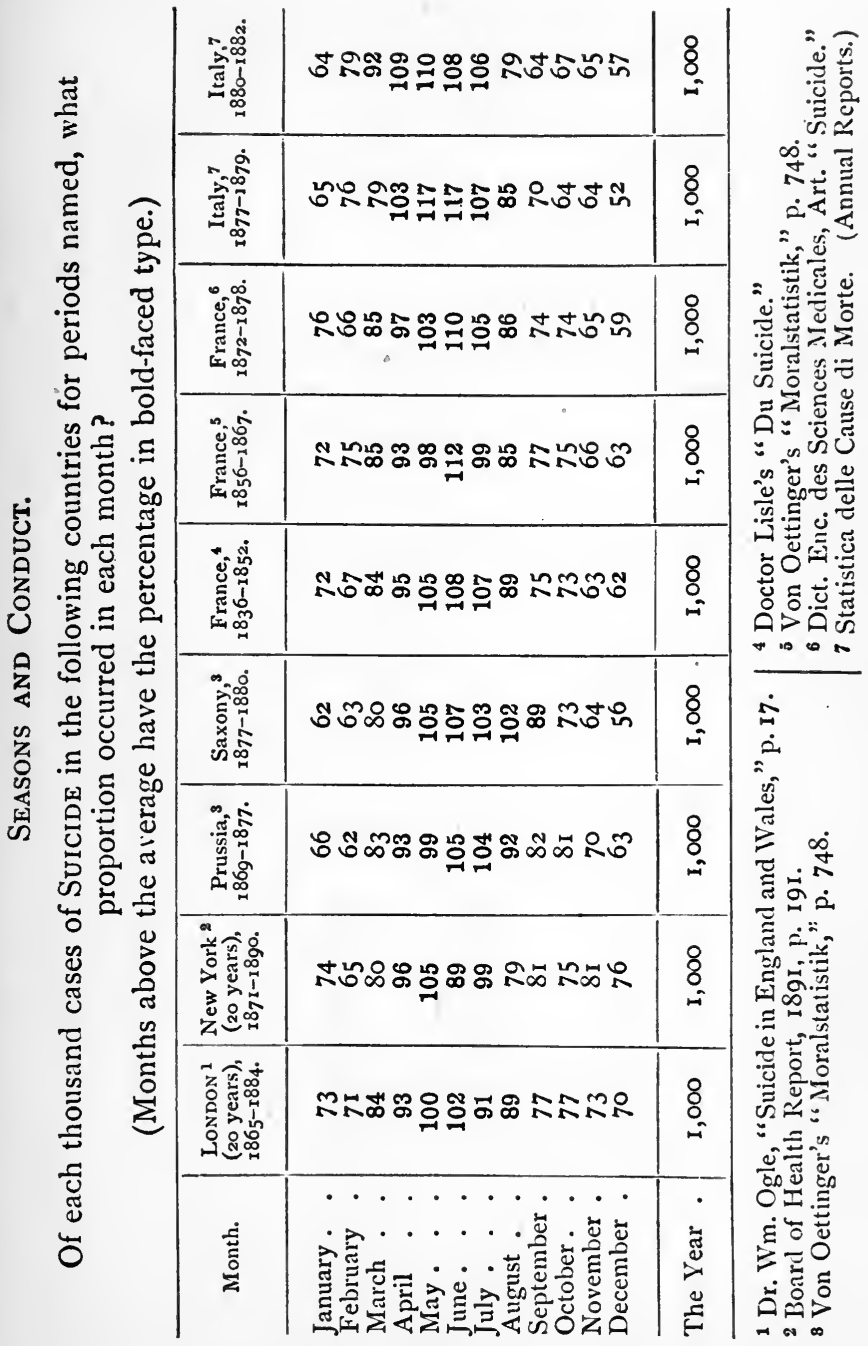




\section{Seasons and Conduct.}

Suicide in Algeria and Japan.

\begin{tabular}{|c|c|c|c|c|}
\hline Seasons. & \multicolumn{2}{|c|}{$\begin{array}{l}\text { Suicides in } \\
\text { Algeria, } \\
\text { 1879-1882.1 }\end{array}$} & \multicolumn{2}{|c|}{$\begin{array}{l}\text { Suicides in } \\
\text { Japan, } \\
1882-1888.2\end{array}$} \\
\hline & Number. & Per Cent. & Number. & Per Cent. \\
\hline $\begin{array}{l}\text { March, April, May } \cdot \cdot \cdot \cdot \cdot \cdot \\
\text { June, July, August } \cdot \dot{*} \cdot \dot{\cdot} \\
\text { September, October, November } \\
\text { December, January, February }\end{array}$ & $\begin{array}{r}\text { I } 51 \\
\text { I } 51 \\
92 \\
\text { IOI }\end{array}$ & $\begin{array}{l}30^{\circ} 5 \\
30^{\circ} 5 \\
190^{\circ} \\
20^{\circ}\end{array}$ & $\begin{array}{r}\text { I } 1,677 \\
\text { I } 2,188 \\
9,070 \\
8,253\end{array}$ & $\begin{array}{l}28 \cdot 4 \\
29 \cdot 6 \\
22 \\
20\end{array}$ \\
\hline Total • • . . . . & 495 & $100 \cdot 0$ & 41,188 & $100 \cdot 0$ \\
\hline
\end{tabular}

1 See Kocher's "La Criminalité chez les Arabes."

2 See "Résumé Statistique de l'Empire du Japon," for 1891.

\section{Seasons and Conduct.}

Number of Attempts at Suicide in England and Wales, I 878-1887.

[Compiled from Judicial Reports.]

\begin{tabular}{|c|c|c|c|c|c|c|}
\hline Year. & & $\begin{array}{c}\text { January } \\
\text { to March. }\end{array}$ & $\begin{array}{l}\text { April to } \\
\text { June. }\end{array}$ & $\begin{array}{c}\text { July to } \\
\text { September. }\end{array}$ & $\begin{array}{l}\text { October to } \\
\text { December. }\end{array}$ & Total. \\
\hline 1878 & & 181 & 272 & 307 & I9I & $95 \mathrm{I}$ \\
\hline I 879 & & 202 & 268 & 334 & 196 & 1,000 \\
\hline I 880 & & 181 & $2 \& 1$ & 308 & 219 & 989 \\
\hline I 88 I & & 167 & 283 & 332 & 202 & 984 \\
\hline I 882 & & 220 & 315 & 330 & 262 & I, 127 \\
\hline I 883 & & 217 & 323 & 296 & 232 & 1,068 \\
\hline 1884 & & 247 & 327 & 387 & 207 & 1,168 \\
\hline 1885 & & 232 & 33, & 566 & 220 & 1,150 \\
\hline 1886 & & I 88 & 318 & 357 & 220 & $\mathrm{I}, 083$ \\
\hline I 887 & & 234 & 375 & 375 & 229 & 1,213 \\
\hline Ten Years & . & 2,069 & 3,094 & 3,392 & 2,178 & 10,733 \\
\hline Percentage & . & $19^{\circ} 3$ & $28 \cdot 8$ & $31 \cdot 6$ & $20 \cdot 3$ & $100^{\circ} 0$ \\
\hline
\end{tabular}




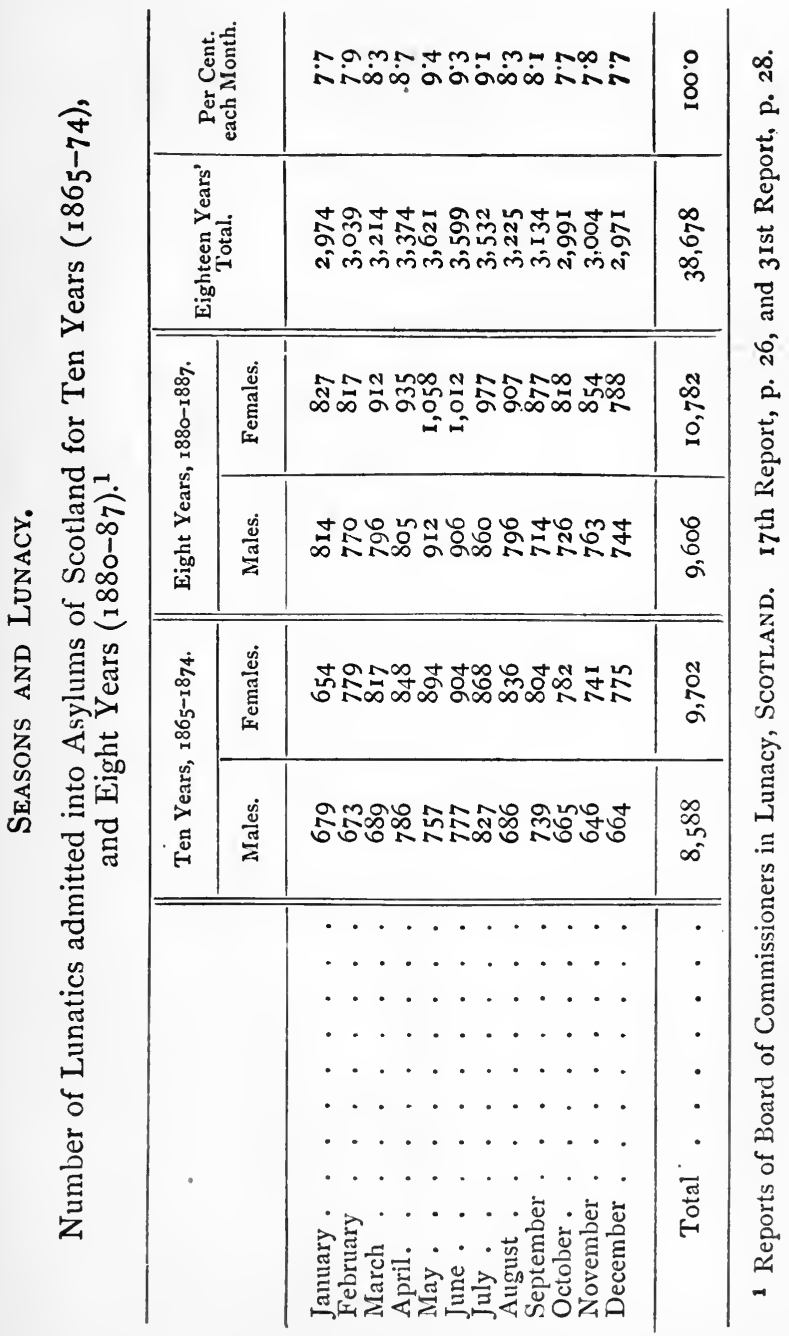




\section{Seasons and Conduct.}

Number of MURDers (of persons over one year), AtTEMpts at Murder and Cases of Manslaughter, England and Wales, during each quarter of the year.

[Compiled from Judicial Reports.]

\begin{tabular}{c||c|c|c|c||c}
\hline Year. & $\begin{array}{c}\text { January to } \\
\text { March. }\end{array}$ & April to June. & $\begin{array}{c}\text { July to } \\
\text { September. }\end{array}$ & $\begin{array}{c}\text { October to } \\
\text { December. }\end{array}$ & Total. \\
\hline I878 & 92 & 101 & 114 & 100 & 407 \\
I879 & 71 & 93 & 107 & 95 & 366 \\
I880 & 84 & 92 & 114 & 104 & 394 \\
I881 & 73 & 98 & 121 & 90 & 382 \\
I882 & 92 & 107 & 110 & 99 & 408 \\
I 883 & 76 & 102 & 95 & 93 & 366 \\
I884 & 106 & 84 & 122 & 91 & 403 \\
I885 & 91 & 109 & 117 & 106 & 423 \\
I886 & 88 & 107 & 129 & 79 & 403 \\
I887 & 90 & 102 & 104 & 100 & 396 \\
& & & & & \\
Ten Years. & 863 & 995 & 1,133 & 957 & 3,948 \\
\hline
\end{tabular}

\section{Seasons and Conduct.}

All Crimes against Persons (not involving Crimes against property), England and Wales.

[Compiled from Judicial Reports.]

\begin{tabular}{|c|c|c|c|c|c|}
\hline Year. & $\begin{array}{l}\text { January to } \\
\text { March. }\end{array}$ & April to June. & $\begin{array}{c}\text { July to } \\
\text { September. }\end{array}$ & $\begin{array}{l}\text { October to } \\
\text { December. }\end{array}$ & Total. \\
\hline $\begin{array}{l}1878 \\
1879 \\
1880 \\
1881 \\
1882 \\
1883 \\
1884 \\
1885 \\
1886 \\
1887\end{array}$ & $\begin{array}{l}656 \\
528 \\
641 \\
582 \\
717 \\
617 \\
682 \\
630 \\
712 \\
706\end{array}$ & $\begin{array}{l}782 \\
675 \\
736 \\
722 \\
870 \\
704 \\
839 \\
755 \\
976 \\
894\end{array}$ & $\begin{array}{r}781 \\
743 \\
759 \\
842 \\
918 \\
793 \\
939 \\
956 \\
1090 \\
989\end{array}$ & $\begin{array}{r}633 \\
719 \\
733 \\
732 \\
695 \\
705 \\
742 \\
848 \\
881 \\
812\end{array}$ & $\begin{array}{l}2,852 \\
2,665 \\
2,869 \\
2,878 \\
3,200 \\
2,819 \\
3,192 \\
3,189 \\
3,659 \\
3,401\end{array}$ \\
\hline Ten Years. & $6,47 \mathrm{I}$ & 7,953 & 8,810 & 7,490 & 30,724 \\
\hline
\end{tabular}


Seasons and Conduct.

Number of Crimes against Chastity (Assaults, Rape, etc.), England and Wales, r878-r 887 .

[Compiled from Table V. Judicial Reports.]

\begin{tabular}{|c|c|c|c|c|c|}
\hline Year. & $\begin{array}{l}\text { January to } \\
\text { March. }\end{array}$ & April to June. & $\begin{array}{c}\text { July to } \\
\text { September. }\end{array}$ & $\begin{array}{l}\text { October to } \\
\text { December. }\end{array}$ & Total. \\
\hline $\begin{array}{l}1878 \\
1879 \\
1880 \\
1881 \\
1882 \\
1883 \\
1884 \\
1885 \\
1886 \\
1887\end{array}$ & $\begin{array}{r}127 \\
99 \\
140 \\
106 \\
139 \\
141 \\
143 \\
133 \\
234 \\
215\end{array}$ & $\begin{array}{l}168 \\
143 \\
181 \\
168 \\
206 \\
179 \\
248 \\
219 \\
368 \\
345\end{array}$ & $\begin{array}{l}167 \\
174 \\
182 \\
210 \\
254 \\
212 \\
256 \\
267 \\
442 \\
379\end{array}$ & $\begin{array}{l}105 \\
126 \\
123 \\
144 \\
101 \\
133 \\
156 \\
234 \\
271 \\
259\end{array}$ & $\begin{array}{r}567 \\
542 \\
626 \\
628 \\
700 \\
665 \\
803 \\
853 \\
1,315 \\
1,198\end{array}$ \\
\hline Ten Years. & $\mathrm{I}, 477$ & 2,225 & 2,543 & 1,652 & 7,897 \\
\hline
\end{tabular}


Crimes against Chastity (Assaults, etc.) in France. Arranged by Season.

Number of Crimes committed.

\begin{tabular}{|c|c|c|c|c|c|}
\hline Year. & $\begin{array}{c}\text { February to } \\
\text { April. }\end{array}$ & May to July. & $\begin{array}{l}\text { August to } \\
\text { October. }\end{array}$ & $\begin{array}{c}\text { November to } \\
\text { January. }\end{array}$ & Total. \\
\hline 1860 & 252 & 283 & 268 & 146 & 949 \\
\hline I 86 I & 160 & 338 & 258 & I 24 & 880 \\
\hline I 862 & 194 & 352 & 236 & 173 & 955 \\
\hline I 863 & I74 & 337 & 290 & $15^{6}$ & 957 \\
\hline 1864 & 2 II & 394 & 287 & 172 & 1,064 \\
\hline I 865 & 201 & 439 & 341 & 196 & 1,177 \\
\hline $\mathrm{r} 86 \overline{6}$ & 227 & 427 & 311 & 191 & I, I 56 \\
\hline I 867 & 201 & 315 & 234 & 172 & 922 \\
\hline I 868 & 187 & 308 & 224 & 132 & $85 I$ \\
\hline I869 & $2 \mathrm{II}$ & 311 & 237 & 177 & 936 \\
\hline Ten Years. & 2,018 & 3,504 & 2,686 & $\mathbf{1 , 6 3 9}$ & 9,847 \\
\hline
\end{tabular}

* From Dr. Tardieu's “Étude Médico-légale sur les Attentats sur Mœurs." On this subject see also articles by Villerme, in "Annales d'Hygiène, 185I," and Bernard in "Archives de l'Anthrop. Criminelle" for I886 and 1887. 


\section{SOCIAL SCIENCE SERIES.}

SCARLET CLOTH, EACH 2S. Gid.

1. Work and Wages.

Prof. J. E. Thorold Rogers. "Nothing that Professor Rogers writes can fail to be of interest to thoughtful people."-A thenaum.

2. Civilisation: its Cause and Cure.

EDWARD CARPENTER.

"No passing piece of polemics, but a permanent possession."-Scottish Review.

3. Quintessence of Sociallsm.

"Precisely the manual needed. Brief, lucid, fair and wise."-British Weeklv.

4. Darwinism and Politics.

D. G. Ritchie, M.A. (Oxon.).

New Edition, with two additional Essays on HuMaN Evolution.

"One of the most suggestive books we have met with."-Literary World.

5. Religion of Socialism.

E. BELFORT BAX.

6. Ethics of Socialism.

E. BELFORT BAX.

"Mr. Bax is by far the ablest of the English exponents of Socialism."-Westminster Review.

7. The Drink Question.

"Plenty of interesting matter for reflection."-Graphic.

8. Promotion of General Happiness. Prof. M. MACMILLAN. "A reasoned account of the most advanced and most enlightened utilitarian doctrine in a clear and readable form."-Scotsman.

9. England's Ideal, \&c.

EDWARD CARPENTER. "The literary power is unmistakable, their freshness of style, their humour, and their enthusiasm." - Pall Mall Gazette.

10. Socialism in England.

SIDNEY WEBB, LL.B. "The best general view of the subject from the modern Socialist side."-Athenaum.

11. Prince Bismarck and State Socialism.

W. H. DAWSON. "A succinct, well-digested review of German social and economic legislation since 1870."-Saturday Review.

12. Godwin's Political Justice (On Property). Edited by H. S. SAlT. "Shows Godwin at his best; with an interesting and informing introduction."Glasgow Herald.

13. The Story of the French Reyolution. $\quad$ E. BELFORT BAX. "A trustworthy outline."-Scotsman.

14. The Co-Operative Commonwealth.

LAURENCE GRONLUND. "An independent exposition of the Socialism of the Marx school."-Contemporary. Review.

15. Essays and Addresses.

Bernard Bosanquet, M.A. (Oxon.). "Ought to be in the hands of every student of the Nineteenth Century spirit."Echo.

"No one can complain of not being able to understand what Mr. Bosanquet: means."-Pall Mall Gazette.

16. Charity Organisation.

C. S. LocH, Secretary to Charity Organisation

Society.

"A perfect little manual:"-Athenaum.

"Deserves a wide circulation."-Scotsman.

17. Thoreau's Anti-Slayery and Reform Papers.

"An interesting collection of essays."-Literary World.

18. Self-Help a Hundred Years Ago.

Edited by H. S. SALT.

"Will a. J. HoLYOAKE, of the condition of the poor."-Morning Post.

19. The New York State Reformatory at Elmira. ALEXANDER WINTEk.

With Preface by HAvelock Ellis.

"A valuable contribution to the literature of penology."-Black and White.

20. Common Sense about Women.

T. W. Higginson.

"An admirable collection of papers, advocating in the most liberal spirit the emancipatiou of women."-Woman's Herald.

21. The Unearned Increment.

"A concise but comprehensive volume."-Echo.

22. Our Destiny.

W. H. DAwSON.

"AAURENCE GRONLUND. and religion."-Daily Chronicle. 


\section{SOCIAL SCIENCE SERIES-(Continued).}

23. The Working-Class Movement in America.

Dr. EDWARD and E. MARX Aveling.

"Will give a good idea of the contition of the working classes in America, and of the various organisations which they have formed."-Scots Leader.

24. Luxury.

Prof. Emile de LAveleye.

"An eloquent plea on moral and economical grounds for simplicity of life."Academy.

25. The Land and the Labourers.

Rev. C. W. Stubbs, M.A. "This admirable book should be circulated in every village in the country."Manchester Guardian.

26. The Exolution of Property.

PAUL LAFARGUE. "Will prove interesti:g and profitable to all students of economic history."Scotsman.

27. Crime and its Causes.

W. DOUglas MORRISON. "Can hardly fail to suggest to all readers several new and pregnant reflections on the subject."-Anti-Jacobin.

28. Principles of State Interference.

D. G. Ritchie, M.A.

"An interesting contribution to the controversy on the functions of the State."Glasgow Herald.

29. German Socialism and F. Lassalle.

W. H. DAwson. "As a biographical history of German Socialistic movements during this century it may be accepted as complete."-British Weekly.

30. The Purse and the Conscience. H. M. Thompson, B.A. (Cantab.). "Shows c mmon sense and fairness in his arguments."-Scotsman.

31. Origin of Property in Land. FUSTEL DE COUlanges. Edited, with an Introductory Chapter on the English Manor, by Prof. W. J. Ashley, M.A. "His views are clearly stated, and are worth reading."-Saturday Revieze.

32. The English Republic. W. J. Linton. Edited by Kineton PARKes. "Characterised by that vigorous intellectuality which has marked his long life of literary and artistic activity."-Glasgow Herald.

33. The Co-Operative Moyement.

Beatrice Potter.

"Without doubt the ablest and most philosophical analysis of the Co-Operative Movement which has yet been produced."-Speaker.

34. Neighbourhood Guilds.

Dr. Stanton Coit. "A most suggestive little book to any one interested in the social question."Pall Mall Gazette.

35. Modern Humanists.

J. M. ROBERTSON.

"Mr. Robertson's style is excellent-nay, even brilliant-and his purely literary criticisms bear the mark of much acumen."-Times.

36. Outlooks from the New Standpoint.

E. Belfort BAX. "Mr. Bax is a very acute and accomplished student of history and economics." -Daily Chronicle.

37. Distr.buting Co-Operative Societies. Dr. Luigi Pizzamiglio. Edited by

F. J. SNell.

"Dr. Pizzamiglio has gathered together and grouped a wide array of facts and statistics, and they speak for themselves."-Speaker.

38. Collectivism and Socialism. By A. NACQueT. Edited by W. HEAfORD.

"An admirable criticism by a well-known French politician of the New Socialism of Marx and Lassalle."-Daily Chronicle.

39. The London Programme.

"Brimful of excellent ideas."-Anti-Jacobin.

40. The Modern State.

SidNey WebB, LL. B. "A most interesting hook; well worth a place in the library of every social inquirer." $-N$. B. Economist.

41. The Condition of Labour.

HENRY GEORGE.

"Written with striking ability, and sure to at tract attention."-Newcastle Chronicle.

42. The Reyolutionary Spirit preceding the French Reyolution.

Felix RocQuain. With a Preface by Professor HuXley.

"The student of the French Revolution will find in it an excellent introduction to the study of that catastrophe."-Scotsman.

.43. The Student's Marx.

"One of the most practically useful of any in the Series."-Glasgow Herald.

$\begin{array}{ll}\text { 14. A Short History of Parliament. } & \text { B. C. SkotTowe, M.A. (Oxon.). }\end{array}$

"Deals very carefully and completely with this side of constitutional history."Spectator. 
45. Poverty : Its Genesis and Exodus.

J. G. GODARD.

"He states the problems with great force and clearness." - N. B. Economist.

46. The Trade Policy of Imperial Federation.

MAURICE H. HERVEY. "An interesting contribution to the discussion."-Publishers' Circular.

47. The Dawn of Radicalism.

J. Bowles DALy, LL.D.

"Forms an admirable picture of an epoch more pregnant, perhaps, with political instruction than any other in the world's history."-Daily Telegraph.

48. The Destitute Alien in Great Britain. ARnold White; Montague Crackanthorpe, Q.C. ; W. A. M'Arthur, M.P.; W. H. Wilkins, \&c. "Much valuable information concerning a burning question of the day."-Times.

49. Illegitimacy and the Influence of Seasons on Conduct.

Albert LefFingwell, M.D.

"We have not often seen a work based on statistics which is more continuously interesting."-Westminster Review.

50 . Commercial Crises of the Nineteenth Century.

H. M. HYNDMAN.

"One of the best and most permanently useful volumes of the Series."-Literary opinion.

51. The State and Pensions in Old Age. J. A Spender and Arthur ACland, M. P. "A careful and cautious examination of the question."-Times.

52. The Fallacy of Saving.

"A plea for the reorganisation of our social and industrial system."-Speaker.

53. The Irish Peasant.

JOHN M. ROBERTSON. investigator."-Daily Chronicle.

54. The Effects of Machinery on Wages.

"Ably reasoned, clearly stated, impartially written."-Literary World.

55. The Social Horizon.

ANON.

"A really admirable little book, bright, clear, and unconventional."-Daily

56. Socialism, Utopian and Scientific.

"The body of the book is still fresh and striking."-Daily Chronicle.

57. Land Nationalisation.

FREDERICK ENGELS. National Reformer.

58. The Ethic of Usury and Interest.

"The work is marked by genuine ability."-North British Agriculturalist.

59. The Emancipation of Women.

ADELE CREPAZ.

"By far the most comprehensive, luminous, and penetrating work on this question that I have yet met with."-Extract from Mr. GLADSTONE's Preface.

60. The Eight Hours' Question.

JOHN M. ROBERTSON. "A very cogent and sustained argument on what is at present the unpopular side."-Times.

61. Drunkenness.

George R. Wilson, M.B.

"Well written, carefully reasoned, free from cant, and full of sound sense."National Observer.

62 The New Reformation.

RAMSDEN BALMFORTH.

"A striking presentation of the nascent religion, how best to realize the personal and social ideal."-Westminster Review.

63. The Agricultural Labourer.

T. E. KEBBEL.

"A short summary of his position, with appendices on wages, education, allotments, etc., etc."

64. Ferdinand Lassalle as a Social Reformer.

"A worthy addition to the Social Science Series."-North British Economist.

65. England's Foreign Trade in XIXth Century.

"Full of valuable information, carefully compiled."-Times.

66. Theory and Policy of Labour Protection.

A. L. Bowley.

"An attempt to systematize a conservative

67. History of Rochdale Pioneers.

Dr. SCHÄFFLE.

68. Rights of Women.

Co-Op. News.

M. OSTRAGORSKI.

69. Dwellings of the People.

inged."-Daily Chron.

"A LOCKE WORTHINGTON. Daily Chronicle. 


\section{SOCIAL SCIENCE SERIES-(Continued).}

70. Hours, Wages, and Production.

Dr. BRENTANO. "Characterised by all Professor Brentano's clearness of style."-Economic Review.

71. Rise of Modern Democracy.

CH. BuRgEAUd. "A very useful little volume, characterised by exact research."-Daily Chronicle.

72. Land Systems of Australasia. WM. EPPS. "Exceedingly valuable at the present time of depression and difficulty."Scots. Mag.

73. The Tyranny of Socialism.

Yves Guyot. Pref. by J. H. Levy. "M. Guyot is smart, lively, trenchant, and interesting."-Daily Chronicle.

74. Population and the Social System.

"A very valuable work of an Italian economist."-West. Rev.

75. The Labour Question.

"Will be found extremely useful."-Times.

76. British Freewomen.

77. Suicide and Insanity.

78. A History of Tithes.

79. Three Months in a Workshop.

80. Darwinism and Race Progress.

81. Local Taxation and Finance.

Dr. NiTH.

82. Perils to British Trade.

83. The Social Contract.

84. Labour upon the Land.

85. Moral Pathology.

86. Parasitism, Organic and Social.

87. Allotments and Small Holdings.

T. G. SPYERS.

C. C. Stopes.

Dr. J. K. STRAHAN.

Rev. H. W. Cllarke.

88. Money and its Relations to Prices.

89. Sober by Act of Parliament.

90 . Workers on their Industries.

91. Revolution and Counter-Revolution.

92. Oyer-Production and Crises.

93. Local Goyernment and State Aid.

94. Yillage Communities in India.

95. Anglo-American Trade.

96. A Plain Examination of Socialism.

P. Gohre, with Pref. by Prof. Ely.

Prof. J. B. HAYCRAFT.

G. H. BLUNDEN.

E. Burgis.

J. J. Rousseau. Edited by H. J. TOzer. Edited by J. A. Hobson, M.A. Arthur E. Giles, M.D., B.Sc. MASSART and VANDERVELUE.

97. Commercial Federation \& Colonial

98. Selections from Fourier.

99. Public-House Reform.

100. The Yillage Problem.

101. Toward the Light.

102. Christian Socialism in England.

103. The Philosophers and the French Reyolution.

104. The History of the English Corn Laws.

105. The Biology of British Politics.

106. Rates and Taxes as Affecting Agriculture.

107. A Practical Programme for Working Men.

J. L. GREEN.

L. L. PRICE.

F. A. MACKENZIE.

F. W. Galton.

KARL MARX.

K. RODBERTUS.

S. J. CHAPMAN.

B. H. BAden-Powell, M.A., C.I.E.

S. J. CHAPMAN.

Gustave Simonson, M.A., M.D.

C. GIDE and J. FRANKLIN.

A. N. Cumming. G. F. Millin. L. H. BERENS.

A. V. WOODWORTH.

Prof. P. A. Wadia. Prof. J. S. Nicholson, M.A. Charles H. HARVEY. Prof. J. S. Nicholson, M.A.

EDMOND KELLY.

\section{DOUBLE VOLUMES, 3s. $6 \mathrm{~d}$.}

1. Life of Robert Owen.

2. The Impossibility of Social Democracy : a Second Part of "The Quintessence of Socialism".

3. Condition of the Working Class in England in 1844.

4. The Principles of Social Economy.

5. Social Peace.

6. A Handbook of Socialism:

7. Socialism : its Growth and Outcome.

8. Economic Foundations of Society.

FrEDERICK ENGELS.

Yves GuYot.

G. vON SCHULTZE-GAEverNitZ.

W. D. P. BLISS.

W. MORRIS and E. B. BAX. A. LORIA. 


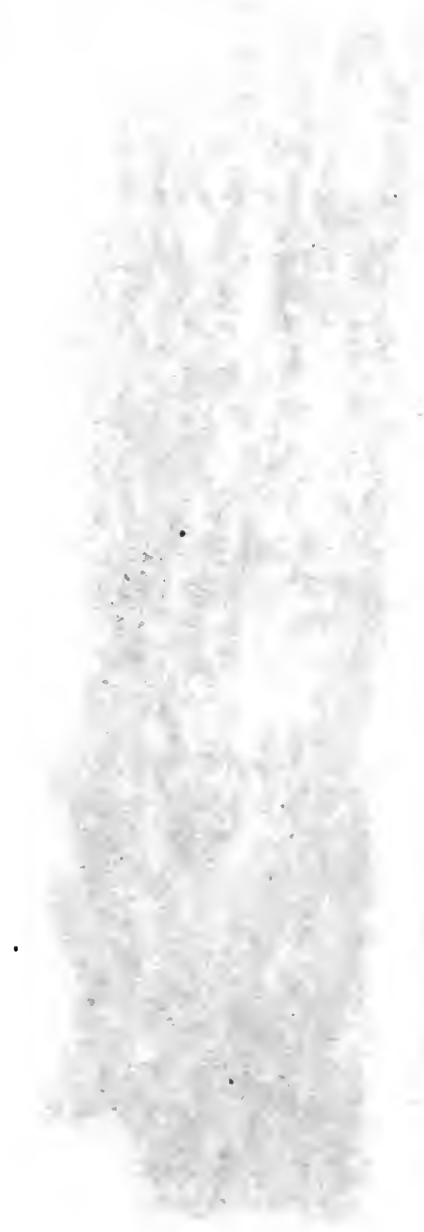

$\because 4$ 


\section{PLEASE DO NOT REMOVE}

CARDS OR SLIPS FROM THIS POCKET

\section{UNIVERSITY OF TORONTO LIBRARY}

HQ

999

G7L 4

1892

cop. 3

FAR BSE $\mathbb{N}$

LIRANY ONLY

Illegitimacy and the influence of seasons upon conduct 
